Final Report

FHWA/IN/JTRP-2009/16

\title{
THE IMPACTS OF BIOFUELS ON TRANSPORTATION AND LOGISTICS IN INDIANA
}

\author{
By \\ Frank Dooley \\ Professor \\ Department of Agricultural Economics \\ Wallace Tyner \\ Professor \\ Department of Agricultural Economics \\ Kumares Sinha \\ Olson Distinguished Professor \\ School of Civil Engineering \\ Justin Quear \\ Graduate Research Assistant \\ Department of Agricultural Economics \\ Lydia Cox \\ Graduate Research Assistant \\ Department of Agricultural Economics \\ Maria Cox \\ Graduate Research Assistant \\ Department of Agricultural Economics \\ Joint Transportation Research Program \\ Project No. C-36-73KK \\ File No. 3-4-7 \\ SPR-3133 \\ Conducted in Cooperation with the \\ Indiana Department of Transportation, \\ the Indiana Department of Agriculture, \\ and the U.S. Department of Transportation \\ Federal Highway Administration
}

The contents of this report reflect the views of the authors, who are responsible for the facts and the accuracy of the data presented herein. The contents do not necessarily reflect the official views or policies of the Indiana Department of Transportation, the Indiana Department of Agriculture, or the Federal Highway Administration at the time of publication. The report does not constitute a standard, specification, or regulation.

Purdue University

West Lafayette, IN 47907

July 2009 


\begin{tabular}{|c|c|c|}
\hline $\begin{array}{l}\text { 1. Report No. } \\
\text { FHWA/IN/JTRP-2009/16 }\end{array}$ & 2. Government Accession No. & 3. Recipient's Catalog No. \\
\hline \multirow{2}{*}{\multicolumn{2}{|c|}{$\begin{array}{l}\text { 4. Title and Subtitle } \\
\text { The Impacts of Biofuels on Transportation and Logistics in Indiana }\end{array}$}} & $\begin{array}{l}\text { 5. } \quad \text { Report Date } \\
\text { July } 2009\end{array}$ \\
\hline & & 6. Performing Organization Code \\
\hline \multicolumn{2}{|c|}{$\begin{array}{l}\text { 7. Author(s) } \\
\text { Frank Dooley, Wallace Tyner, Kumares Sinha, Justin Quear, Lydia Cox, Maria Cox }\end{array}$} & $\begin{array}{l}\text { 8. Performing Organization Report No. } \\
\text { FHWA/IN/JTRP-2009/16 }\end{array}$ \\
\hline \multirow{2}{*}{\multicolumn{2}{|c|}{$\begin{array}{l}\text { 9. Performing Organization Name and Address } \\
\text { Joint Transportation Research Program } \\
\text { 1284 Civil Engineering Building } \\
\text { Purdue University } \\
\text { West Lafayette, IN 47907-1284 }\end{array}$}} & 10. Work Unit No. \\
\hline & & $\begin{array}{l}\text { 11. Contract or Grant No. } \\
\text { SPR-3133 }\end{array}$ \\
\hline \multirow{2}{*}{\multicolumn{2}{|c|}{$\begin{array}{l}\text { 12. Sponsoring Agency Name and Address } \\
\text { Indiana Department of Transportation } \\
\text { State Office Building } \\
100 \text { North Senate Avenue } \\
\text { Indianapolis, IN } 46204\end{array}$}} & $\begin{array}{l}\text { 13. Type of Report and Period Covered } \\
\text { Final Report }\end{array}$ \\
\hline & & 14. Sponsoring Agency Code \\
\hline \multicolumn{3}{|l|}{ 15. Supplementary Notes } \\
\hline
\end{tabular}

\section{Abstract}

Like the rest of the US, the ethanol industry in Indiana has rapidly expanded, growing from one plant in 2006 to a projected 13 by 2010. One result of this expansion is that truck and rail traffic flows in Indiana are shifting, as more corn and beans are processed in state. Most of the change in transportation requirements will likely be concentrated in regions of Indiana where the ethanol plants are constructed.

The goal of this work was to determine how the entry of ethanol and biodiesel plants changes the inbound and outbound transportation flows of corn, soybeans, DDGS, and ethanol at the county level in Indiana between 2006 and 2010 , focusing on modal and market shifts.

The addition of 12ethanol and 2 biodiesel plants from 2006 to 2010 increases total annual truckloads by 8\%, but VMTs by $39 \%$. This is due to fewer short hauls of corn and beans to local grain elevators replaced by longer hauls to ethanol plants. In addition, the movement of DDGS and ethanol is largely by truck. As more grain is processed within Indiana, less is shipped to out-of-state users by rail. However, outbound rail movements of ethanol and DDGS offset this somewhat. Finally, the changes in traffic flows are heavily concentrated in those counties with ethanol plants.

As more ethanol plants are constructed, transportation requirements will change. Increases in the volume of truck traffic (more trucks and more miles traveled by each truck) will increase damage on local roads. This research identifies regions with large increases in truck traffic resulting from new ethanol and biodiesel plants. In turn, transportation planners can anticipate a reallocation of maintenance budgets to maintain key highways and bridge

\author{
17. Key Words \\ Biofuels, ethanol, biodiesel, transportation, logistics
}

18. Distribution Statement

No restrictions. This document is available to the public through the National Technical Information Service, Springfield, VA 22161

\author{
19. Security Classif. (of this report) \\ Unclassified
}

\author{
20. Security Classif. (of this page) \\ Unclassified
}

\begin{tabular}{|c|c|}
\hline 21. No. of Pages & 22. Price \\
90 &
\end{tabular}

Form DOT F 1700.7 (8-69) 


\section{Table of Contents}

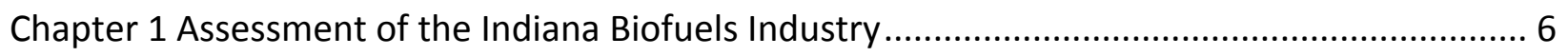

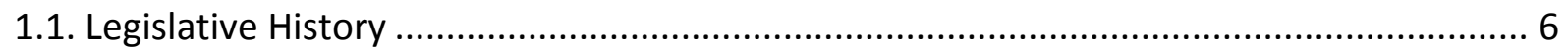

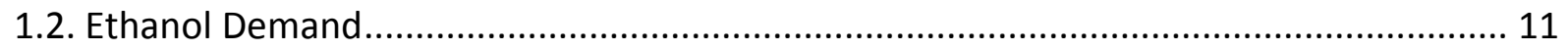

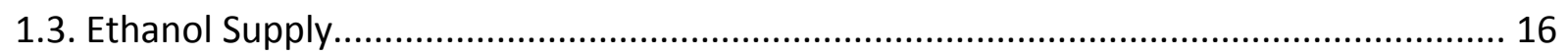

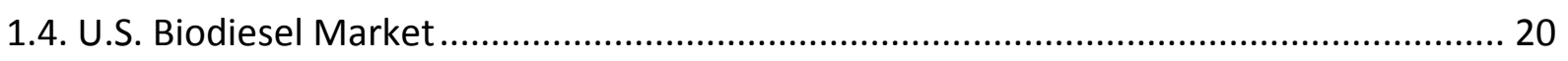

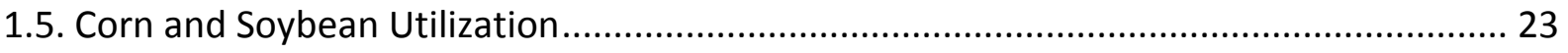

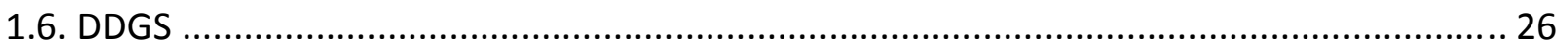

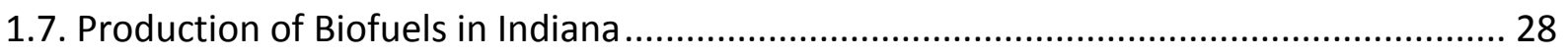

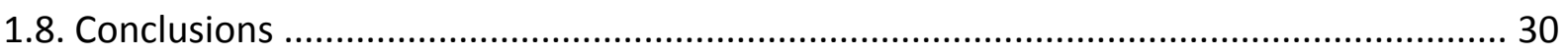

Chapter 2 .DATA, ASSUMPTIONS AND MODEL DEVELOPMENT ............................................. 31

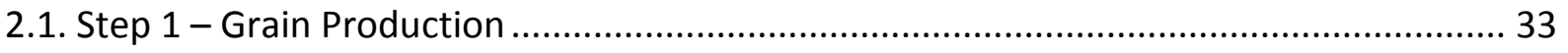

2.2. Step 2 - Livestock Feed Demand for DDGS............................................................ 34

2.3. Step 3 - Livestock Feed Demand for Corn ................................................................. 39

2.4. Step 4 - Estimate Livestock Transportation Requirements....................................... 40

2.5. Step 5 - Corn for Food Processing and Ethanol ........................................................ 41

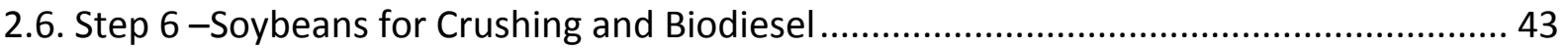

2.7. Step 7 - Transportation Requirements for Ethanol to Blenders ................................. 44

2.8. Step 8 - Grain Shipped from Grain Elevators ........................................................ 46

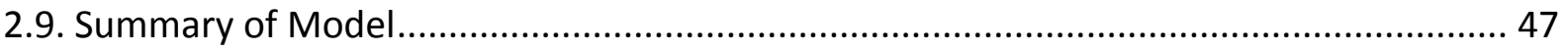

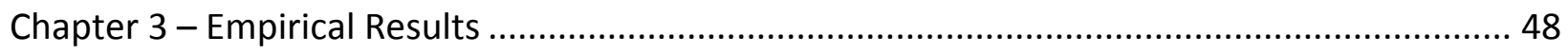

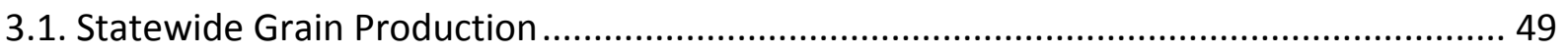

3.2. Statewide Outbound Ethanol, DDGS, and Grain Flows ............................................ 55

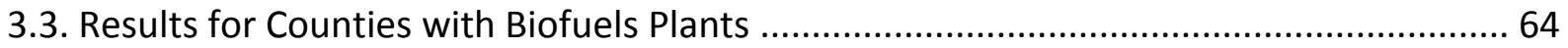

3.4. Results for Counties Adjacent to Biofuels Production Counties................................... 68

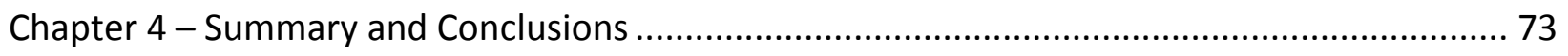

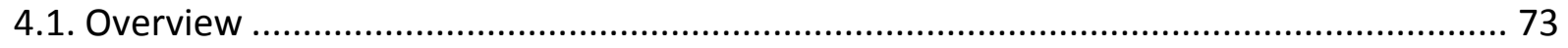

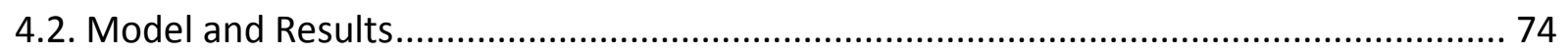

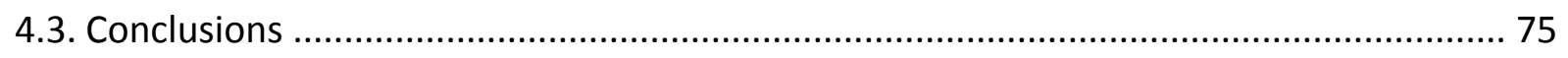




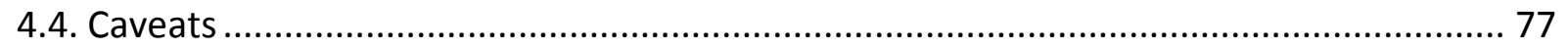

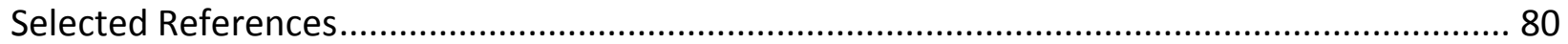

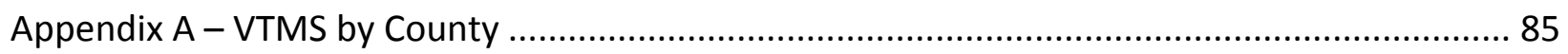




\section{List of Tables}

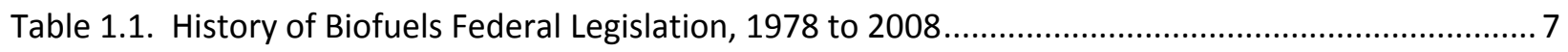

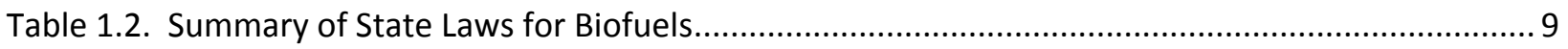

Table 1.3. E10 Potential Demand and 2007 Ethanol Consumption, by PADD ...................................... 14

Table 1.4. US Gasoline Consumption by Type, and Proportion Blended with Ethanol, 2008 ..................16

Table 1.5. Ethanol Capacity and Number of Plants, by Association, Spring 2009 .................................. 18

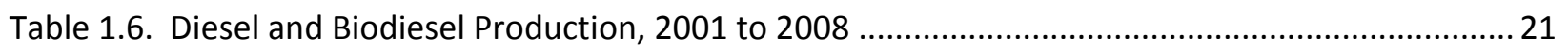

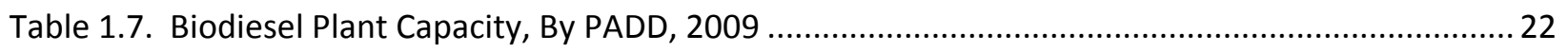

Table 1.8. Indiana Ethanol Plants, by Year, Location, and Capacity, March 2009 ...................................29

Table 1.9. Indiana Biodiesel Plants, by Year, Location, and Capacity, March 2009................................29

Table 2.1. Assumed Indiana Ethanol and Biodiesel Capacity and Grain Requirements, by Year ............. 31

Table 2.2. Indiana Corn and Soybean Production, by Year .................................................................. 34

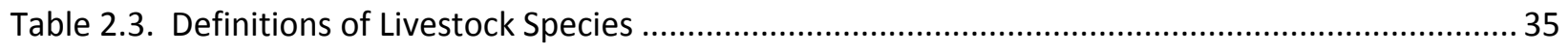

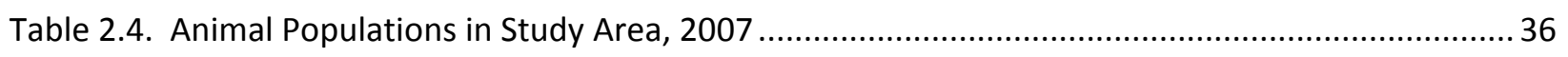

Table 2.5. DDGS and Corn Annual Feeding Rates per Head, by Species, by Year................................. 37

Table 2.6. Location and Annual Utilization of Corn by Food Processing Plants in Indiana, 2009............. 41

Table 2.7. Location and Capacity of Soybean Crushing Plants......................................................... 44

Table 2.8. Assumed Location and Annual Demands for Ethanol Truck Markets ..................................... 45

Table 2.9. Distribution of Outbound Shipments by Mode and Bushels Shipped, 2002 ........................47

Table 3.1. Indiana Grain Production, Yield, and Density, by Year....................................................... 49

Table 3.2. Truckloads, VMT, and Average LOH for Livestock Utilization of Corn, by Year .......................50

Table 3.3. Truckloads, VMT, and Average LOH for Food Processing Utilization of Corn, by Year ............. 51

Table 3.4. Truckloads, VMT, and Average Trip Miles for Ethanol Utilization of Corn, by Year..................52

Table 3.5. Truckloads, VMT, and Average LOH for Elevator Utilization of Corn, by Year .........................54 
Table 3.6. Truckloads, VMT, and Average LOH for Crushers Utilization of Soybeans, by Year .54

Table 3.7. Truckloads, VMT, and Average LOH for Elevator Utilization of Soybeans, by Year........ .55

Table 3.8. Truck and Rail Loads, VMT, and LOH for Outbound Ethanol, by Year .56

Table 3.9. Truck and Rail Loads, VMT, and Average LOH for Outbound DDGS, by Year ...... 57

Table 3.10. Truckloads, Rail Carloads, VMT, and Average LOH for Outbound Corn, by Year. .58

Table 3.11. Truckloads, Rail Carloads, VMT, and Average LOH for Outbound Soybeans, by Year 59

Table 3.12. Summary of Corn Utilization by Type, by Year..... 60

Table 3.13. Summary of Soybean Utilization by Type, by Year. 60

Table 3.14. Annual Truckloads and Rail Carloads by Commodity, by Year...... .61

Table 3.15. Annual VMT by Commodity, by Year 62

Table 3.16. Annual Inbound Truckloads for Counties with New Biofuels Plants 65

Table 3.17. Annual Inbound VMT for Counties with New Biofuels Plants. 65

Table 3.18. Annual Outbound Trucks from Indiana for Counties with New Biofuels Plants .66

Table 3.19. Annual Outbound VMT for Counties with New Biofuels Plants 67

Table 3.20. Annual Outbound Rail Carloads from Counties with Biofuels Plants 67

Table 3.21. Annual Distribution of Loads, By Type of County, 2010 69

Table 3.22. Annual Distribution of VMTs, By Type of County, 2010 69

Table 3.23. Net Change in Annual Loads from 2006 to 2010, by Type of County 70

Table 3.24. Net Change in Annual VMTs from 2006 to 2010, by Type of County 71 


\section{List of Figures}

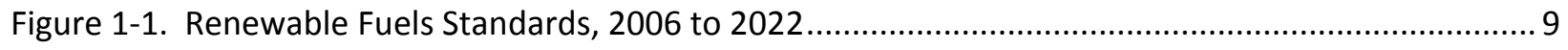

Figure 1-2. U.S. Oxygenate Production (Ethanol and MTBE), 1992-2008_........................................ 11

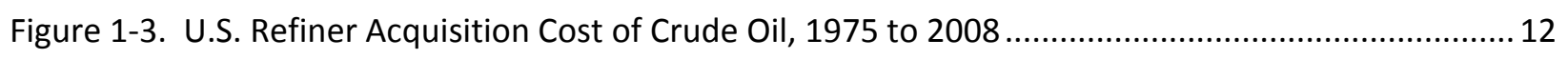

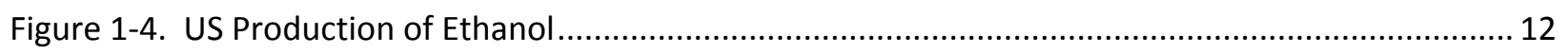

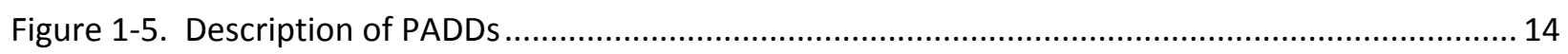

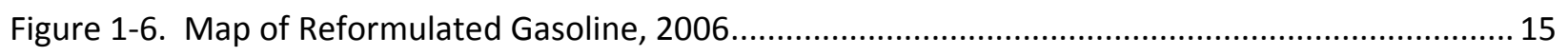

Figure 1-7. USDA and DOE Forecasts of Ethanol Production and Imports, 2007 to $2030 \ldots \ldots \ldots \ldots \ldots \ldots \ldots . . . . . . . . .17$

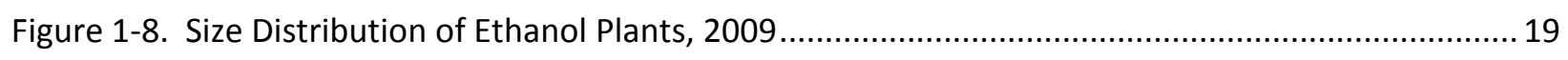

Figure 1-9. Built and Operating Capacity for Corn Ethanol Plants, by State, 2009............................... 20

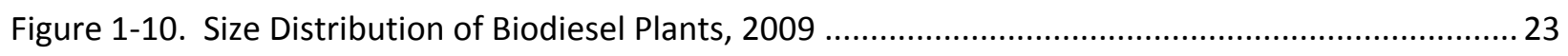

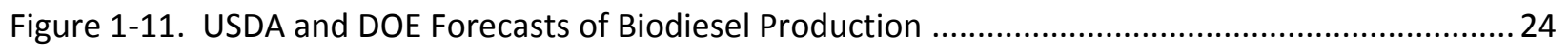

Figure 1-12. Corn Utilization for Feed, Food, Exports, and Ethanol, 2001 to 2018 ............................... 25

Figure 1-13. Soybean Utilization for Crush, Seed, Biodiesel and Exports, 2001 to 2018......................... 25

Figure 1-14. Corn and Soybean Harvested Acres in United States, 1990-20087.................................. 26

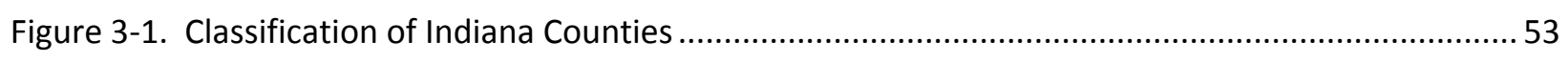

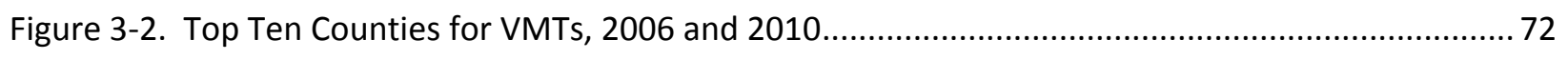




\section{Chapter 1 Assessment of the Indiana Biofuels Industry}

The rapid growth of ethanol production since 2005 is leading to far-reaching changes in grain marketing and transportation. Federal and state legislation are key drivers underlying this change, with policy changes leading to the current rapid expansion in industry capacity. In turn, this expansion has affected markets for corn, other crops, and the principal co-product of ethanol production, distillers dried grains and solubles (DDGS). After investigating national trends for biofuels expansion, impacts are considered for Indiana. This chapter will discuss the legislative history of biofuels, U.S. ethanol and biodiesel demand and supply, corn and soybean production and utilization, and DDGS. Information in this report is based on a literature review, focusing on publications since 2002 .

\subsection{Legislative History}

The success of the ethanol industry has been closely tied to agricultural and energy policies since 1978. Over the past 30 years, federal biofuels policy has included tax exemptions, production credits, and tariffs on ethanol imports. The Energy Tax Act of 1978 created a 4 cent per gallon federal tax exemption for gasoline containing at least a 10 percent ethanol (E10). This is equivalent to a 40 cent per gallon subsidy on ethanol. Since then, tax exemptions have fluctuated between 40 and 60 cents per gallon of ethanol, and currently is 45 cents per gallon (Table 1.1). Initially, ethanol subsidies were justified as both a means of rural economic development (by increasing a local demand for corn) and for producing energy domestically from renewable sources. With the passage of the Clean Air Act in 1990, ethanol was also 
Table 1.1. History of Biofuels Federal Legislation, 1978 to 2008

\begin{tabular}{|c|c|}
\hline Act & Key Features \\
\hline Energy Tax Act of 1978 & $\begin{array}{l}\$ 0.40 \text { per gallon of ethanol tax exemption on the } \$ 0.04 \\
\text { gasoline excise tax }\end{array}$ \\
\hline $\begin{array}{l}\text { Crude Oil Windfall Profit Tax } \\
\text { Act and the Energy Security Act } \\
-1980\end{array}$ & $\begin{array}{l}\text { Promoted energy conservation and domestic fuel } \\
\text { development }\end{array}$ \\
\hline $\begin{array}{l}\text { Surface Transportation } \\
\text { Assistance Act - } 1982\end{array}$ & $\begin{array}{l}\text { Increased tax exemption to } \$ 0.50 \text { per gallon of ethanol and } \\
\text { increased the gasoline excise tax to } \$ 0.09 \text { per gallon }\end{array}$ \\
\hline Tax Reform Act - 1984 & Increased tax exemption to $\$ 0.60$ per gallon of ethanol \\
\hline $\begin{array}{l}\text { Alternative Motor Fuels Act - } \\
1988\end{array}$ & $\begin{array}{l}\text { Created research and development programs and provided } \\
\text { fuel economy credits to automakers }\end{array}$ \\
\hline $\begin{array}{l}\text { Omnibus Budget Reconciliation } \\
\text { Act - } 1990\end{array}$ & $\begin{array}{l}\text { Ethanol tax incentive extended to } 2000 \text { but decreased to } \\
\$ 0.54 \text { per gallon of ethanol }\end{array}$ \\
\hline Clean Air Act - 1990 & Acknowledged contribution of motor fuels to air pollution \\
\hline Energy Policy Act - 1992 & Tax deductions allowed on vehicles that could run on E85 \\
\hline $\begin{array}{l}\text { Transportation Efficiency Act of } \\
\text { the 21st Century - } 1998\end{array}$ & $\begin{array}{l}\text { Ethanol subsidies extended through } 2007 \text { but reduced to } \\
\$ 0.51 \text { per gallon of ethanol by } 2005\end{array}$ \\
\hline Jobs Creation Act -2004 & $\begin{array}{l}\text { Changed the mechanism of the ethanol subsidy to a blender } \\
\text { tax credit instead of the previous excise tax exemption. } \\
\text { Extended the ethanol tax exemption to } 2010 \text {. }\end{array}$ \\
\hline Energy Policy Act - 2005 & $\begin{array}{l}\text { Established the Renewable Fuel Standard starting at } 4 \text { billion } \\
\text { gallons in } 2006 \text { and rising to } 7.5 \text { billion in } 2012 \text {. }\end{array}$ \\
\hline $\begin{array}{l}\text { Energy Independence and } \\
\text { Security Act of } 2007\end{array}$ & $\begin{array}{l}\text { Raised the RFS to } 36 \text { billion gallons, with } 15 \text { billion gallons } \\
\text { per year (BGY from corn ethanol, } 1 \text { BGY from biodiesel and } \\
20 \text { BGY from advanced biofuels by 2022.) }\end{array}$ \\
\hline $\begin{array}{l}\text { Food, Conservation, and } \\
\text { Energy Act of } 2008\end{array}$ & $\begin{array}{l}\text { Lowers per gallon ethanol subsidy for starch based ethanol } \\
\text { to } \$ 0.45 \text {, adds subsidy of } \$ 1.01 \text { for cellulosic ethanol. }\end{array}$ \\
\hline
\end{tabular}

Source: Clean Fuels Development Coalition (2007) and Sissine (2007).

viewed as an oxygenate with environmental benefits as compared to methyl tertiary-butyl ether (MTBE). The Energy Policy Act of 2005 lacked provisions shielding MTBE manufacturers from water contamination lawsuits, which in effect ended blenders' usage of MTBE in July of 2006. Most recently, ethanol and other alternative domestic fuels are seen as a means of reducing the national security cost of imported oil. 
The Energy Conservation Reauthorization Act of 1998 allowed biodiesel to qualify as a renewable fuel to meet public utility alternative fuel requirements (Table 1.1). Governmental agencies led the switch to biodiesel. In 2005, the biodiesel blenders' tax credit was established, providing $\$ 1.00$ per gallon for agri-biodiesel produced from virgin oils, either from crops or animal fats. A small biodiesel producer tax credit is available for producers of biodiesel who annually produce less than 60 million gallons.

In 2005, the Renewable Fuel Standard (RFS) mandated a minimum amount of renewable fuel that must be used for US automobile fuel consumption. The volume of renewable fuel required to be blended into gasoline started at 4.0 billion gallons in calendar year 2006 . The Energy Independence and Security Act of 2007 increased the RFS to 36 billion gallons of biofuels by 2022 (Yacobucci and Capehart, 2008). Of this, up to 15 billion gallons is starch based ethanol (typically corn), up to 1 billion gallons is biodiesel, and the remainder is advanced biofuels (Figure 1.1). Concerns have been expressed that ethanol might not achieve the reduction in life cycle greenhouse gas emissions relative to emissions from gasoline and diesel, as required by the law (Searchinger et al., 2008).

States also provide various types of incentives for biofuels production and/or retailing to promote development within their boundaries (Table 1.2). Retailer incentives are found in 44 states, including 11 states with excise tax exemptions, 11 states with programs for new gas station infrastructure (E85 pumps) and 22 states with both. Producer incentives, such as low interest loans or grants, are found in 30 states. In addition, 24 states ban MTBEs and 13 states require use of biofuels through renewable fuels standards. Only the District of Columbia, Nevada, and West Virginia have no state level program of any type for ethanol or biodiesel. 
Figure 1-1. Renewable Fuels Standards, 2006 to 2022

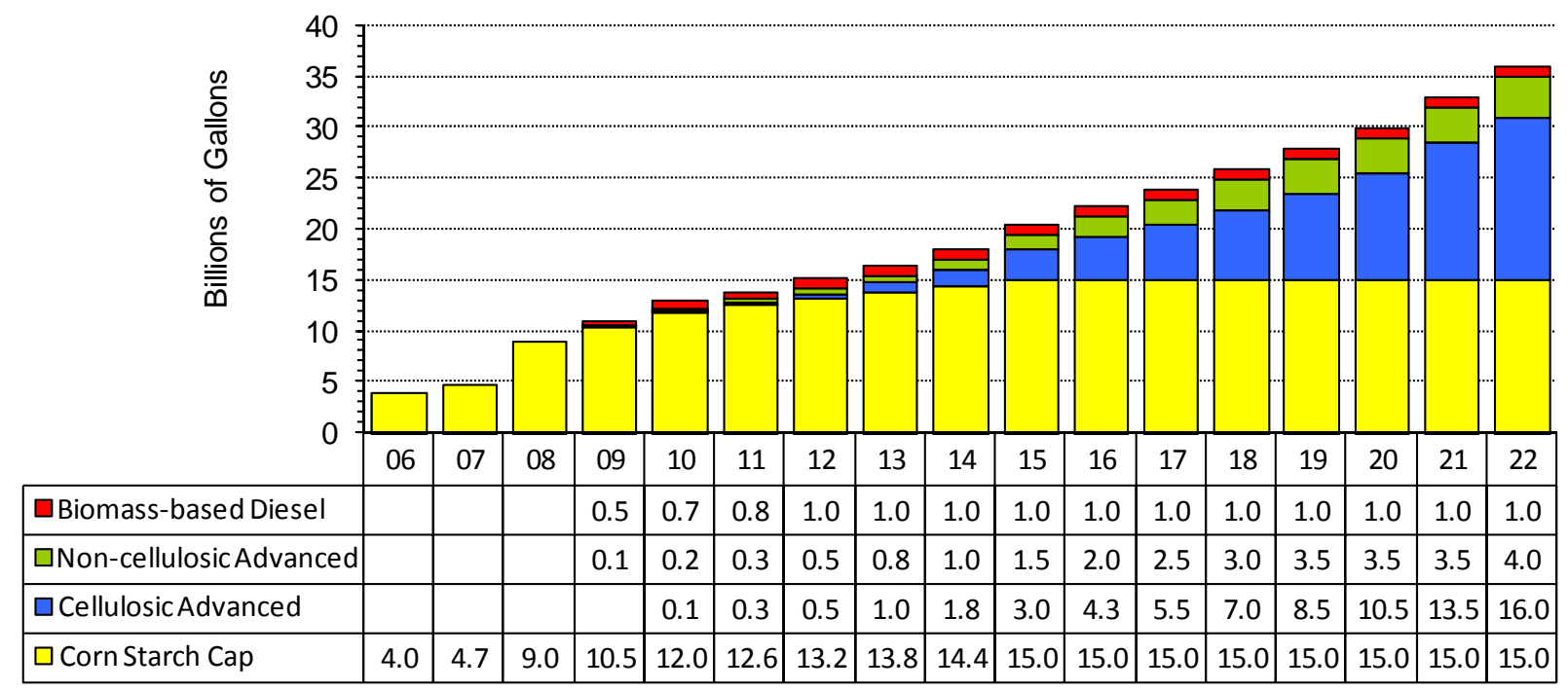

Source: Yacobucci and Capehart, 2008.

Table 1.2. Summary of State Laws for Biofuels

\begin{tabular}{|c|c|c|c|c|}
\hline State & $\begin{array}{c}\text { Renewable Fuel } \\
\text { Standard }\end{array}$ & Retailer Incentive & Producer Incentive & MTBE Ban \\
\hline Alabama & & Pumps & & \\
\hline Alaska & & Tax & & \\
\hline Arizona & & Pumps & & MTBE Ban \\
\hline Arkansas & & Tax and Pumps & Loan/grant & \\
\hline California & & Pumps & & MTBE Ban \\
\hline Colorado & & Pumps & Loan/grant & MTBE Ban \\
\hline Connecticut & & & Loan/grant & MTBE Ban \\
\hline $\begin{array}{l}\text { Delaware } \\
\text { DC }\end{array}$ & & Tax & & \\
\hline Florida & Ethanol Blend & Tax & Loan/grant & \\
\hline Georgia & & Tax and Pumps & Loan/grant & \\
\hline Hawaii & RFS & Tax & Loan/grant & \\
\hline İaho & & Tax and Pumps & & \\
\hline Illinois & & Tax and Pumps & Loan/grant & MTBE Ban \\
\hline Indiana & & Tax and Pumps & Loan/grant & MTBE Ban \\
\hline lowa & RFS & Tax and Pumps & Loan/grant & MTBE Ban \\
\hline Kansas & & Tax and Pumps & Loan/grant & MTBE Ban \\
\hline Kentucky & & Pumps & Loan/grant & MTBE Ban \\
\hline
\end{tabular}


Table 1-2 continued

\begin{tabular}{|c|c|c|c|c|}
\hline State & $\begin{array}{c}\text { Renewable Fuel } \\
\text { Standard }\end{array}$ & Retailer Incentive & Producer Incentive & MTBE Ban \\
\hline Louisiana & RFS & Pumps & & \\
\hline Maine & & Tax and Pumps & Loan/grant & MTBE Ban \\
\hline Maryland & & & Loan/grant & \\
\hline Massachusetts & Biodiesel Blend & Tax & & \\
\hline Michigan & & Tax and Pumps & & MTBE Ban \\
\hline Minnesota & Biofuels Blend & Tax and Pumps & Loan/grant & MTBE Ban \\
\hline Mississippi & & & Loan/grant & \\
\hline Missouri & Ethanol Blend & Tax and Pumps & Loan/grant & MTBE Ban \\
\hline Montana & Ethanol Blend & Tax & Loan/grant & MTBE Ban \\
\hline Nebraska & & Tax and Pumps & Loan/grant & MTBE Ban \\
\hline \multicolumn{5}{|l|}{ Nevada } \\
\hline N Hampshire & & Pumps & & MTBE Ban \\
\hline New Jersey & & Pumps & & MTBE Ban \\
\hline New Mexico & Biodiesel Blend & Tax and Pumps & & \\
\hline New York & & Tax and Pumps & Loan/grant & MTBE Ban \\
\hline North Carolina & Ethanol Blend & Tax and Pumps & Loan/grant & MTBE Ban \\
\hline North Dakota & & Tax & Loan/grant & \\
\hline Ohio & & Tax and Pumps & Loan/grant & MTBE Ban \\
\hline Oklahoma & & Tax and Pumps & Loan/grant & \\
\hline Oregon & RFS & Tax and Pumps & Loan/grant & \\
\hline Pennsylvania & RFS & Tax and Pumps & Loan/grant & \\
\hline Rhode Island & & Tax & & MTBE Ban \\
\hline South Carolina & & Tax and Pumps & Loan/grant & \\
\hline South Dakota & & Tax & Loan/grant & MTBE Ban \\
\hline Tennessee & & Pumps & Loan/grant & \\
\hline Texas & & Tax & & \\
\hline Utah & & Pumps & & \\
\hline Vermont & & & & MTBE Ban \\
\hline Virginia & & Tax and Pumps & Loan/grant & \\
\hline Washington & RFS & Tax and Pumps & Loan/grant & MTBE Ban \\
\hline \multicolumn{5}{|l|}{ West Virginia } \\
\hline Wisconsin & & Pumps & & \\
\hline Wyoming & & Tax & & \\
\hline
\end{tabular}

Adapted from American Coalition for Ethanol (2007) and Renewable Fuels Association (2009). 


\subsection{Ethanol Demand}

In the late 1970s, ethanol was viewed as a domestic alternative to gasoline and the market power of OPEC. When oil prices declined in the mid-1980s, so did the idea of ethanol as a gasoline alternative. From 1978 to 2004 , subsidies were the primary factor driving the ethanol markets (Sarmiento and Wilson, 2008). Oil price increases since 2004 once again led to legislation supporting ethanol as a gasoline alternative. However, as important to the renewed interest in ethanol were state level bans on MTBE and the lack of federal legislative support for MTBE. As recent as 2002, MTBE held $60 \%$ of the market for oxygenates (Figure 1-2). In 2008, ethanol was $93 \%$ of the US oxygenates, while small amounts of MTBE are still being produced.

Figure 1-2. U.S. Oxygenate Production (Ethanol and MTBE), 1992-2008

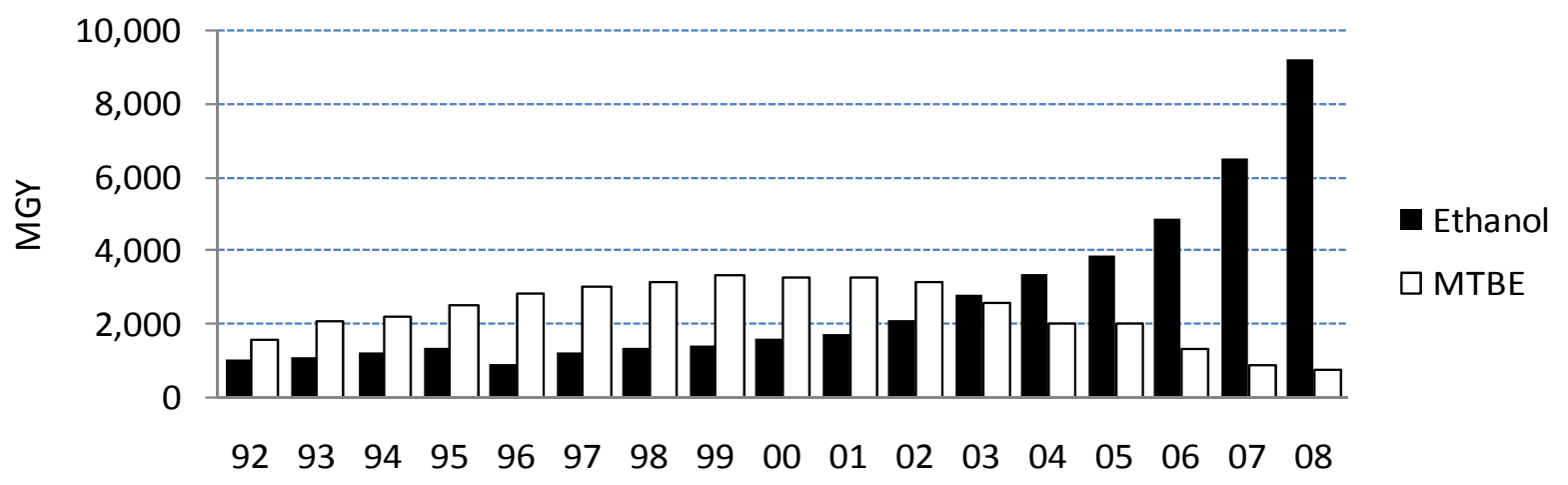

Source: Energy Information Administration, 2009e. Oxygenate Production.

From 1982 to 2004, oil price per barrel was relatively steady, hovering between $\$ 10$ and $\$ 30$ per barrel (Figure 1-3). Over this time, ethanol production grew steadily from 175 million gallons per year (MGY) in 1982 to 1.6 billion gallons per year (BGY) in 2001 (Figure 1-4). Since 2004, oil prices quadrupled in response to economic growth in China and India, supply 
Figure 1-3. U.S. Refiner Acquisition Cost of Crude Oil, 1975 to 2008

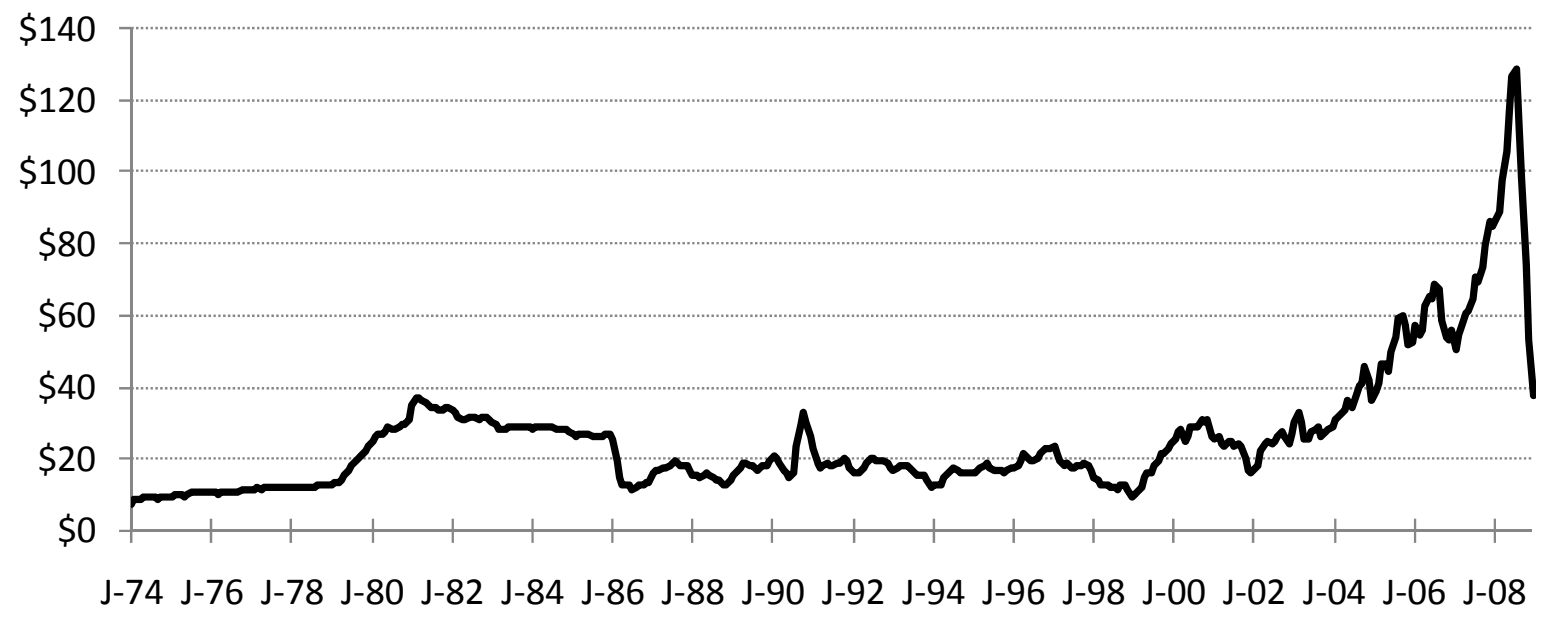

Source: Energy Information Administration, 2009g. Refiner Acquisition Cost of Crude Oil."

Figure 1-4. US Production of Ethanol

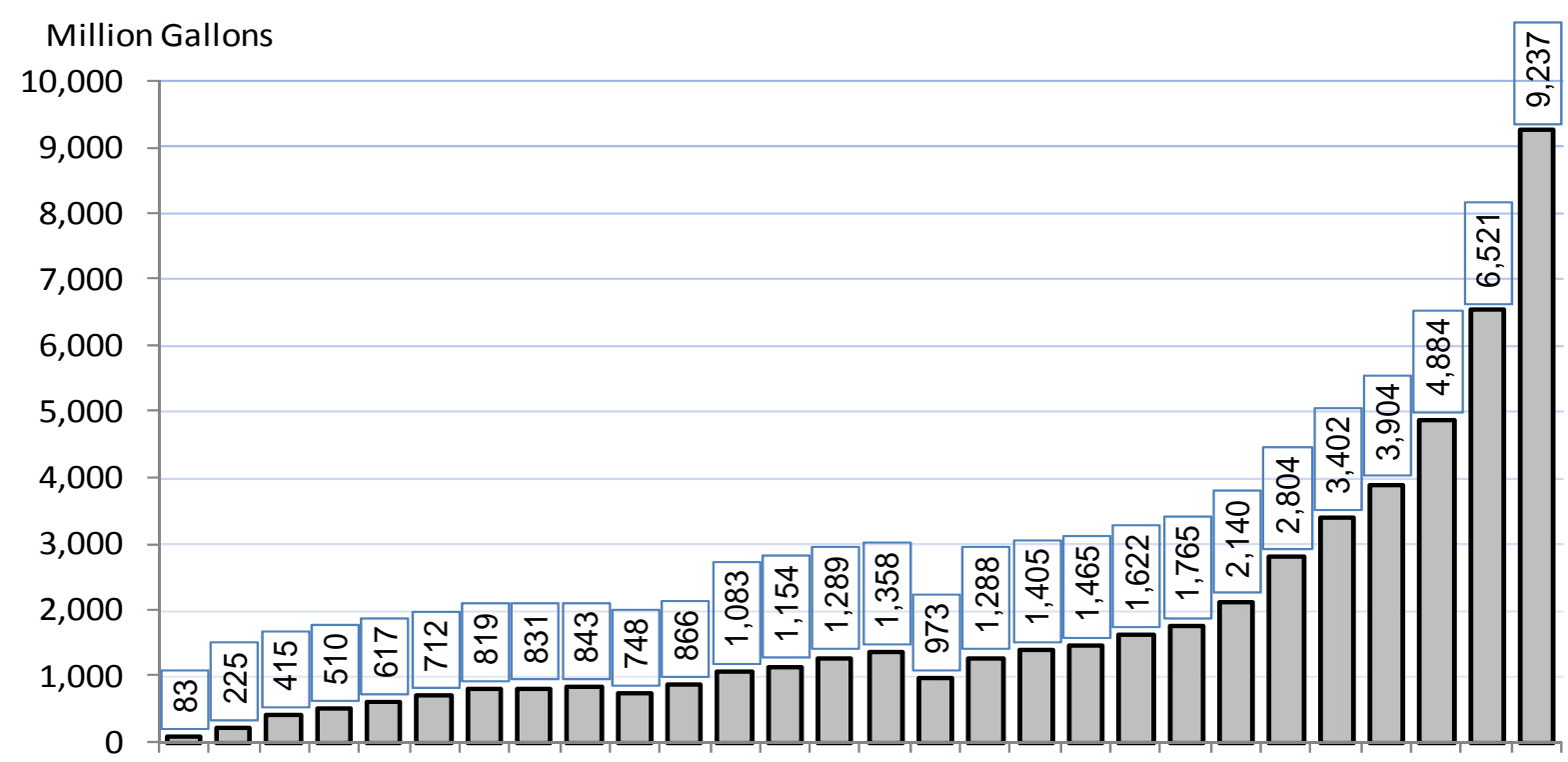

81828384858687888990919293949596979899000102030405060708

SOURCE: Energy Information Administration, 2009e. Oxygenate Production. 
disruptions from hurricanes, and turmoil in the Mideast and other oil producing regions, before sliding in 2008 with the global economic meltdown. In response to higher oil prices, ethanol production more than doubled from rose from 2.1 to $9.2 \mathrm{BGY}$ from 2002 to in 2008.

Ethanol demand is complicated given ethanol's dual nature of being both a component of and a substitute for gasoline. Initially, ethanol was primarily an oxygenate additive to gasoline. Thus, its demand was derived from motorist's demand for gasoline. However, an additional demand for ethanol arises from its use as an alternative fuel to gasoline, especially when run in flexible fuel vehicles (FFVs). Over 6 million FFVs have been produced since 1992, in part because auto manufacturers can offset CAFE requirements (Energy Information Administration, 2007a). The number of FFVs is projected to grow to 10 million vehicles by 2010 (Denicoff, 2007). The adoption of E85 will require an expansion in the number of E85 gas stations. Only around 1 percent of the gasoline stations $(1,877$ of 170,000$)$ handle E85 as of May 2009 (Energy Information Administration, 2009a).

Focusing on E10, demand is driven by "the need for ethanol as a fuel oxygenate to meet Federal gasoline specifications and as an octane enhancer and because of the blender's tax credit" (Energy Information Administration, 2007a). All cars and light trucks manufactured since the late 1970s can run on E10. If all gasoline in the US were blended as E10, demand would be approximately 14 billion gallons (Table 1.3). The US Department of Energy reports information for petroleum on the basis of Petroleum Administration for Defense Departments (PADDs) (Figure 1-5). The market potential for E10 is strong across the country, but especially so in the Central and Lower Atlantic States, the Gulf Coast (i.e., Texas), and California. 
Table 1.3. E10 Potential Demand and 2007 Ethanol Consumption, by PADD

\begin{tabular}{llrrr}
\hline PADD & \multicolumn{1}{c}{ States } & $\begin{array}{r}\text { E10 Potential } \\
\text { Demand }\end{array}$ & $\begin{array}{r}\text { 2007 Ethanol } \\
\text { Consumption }\end{array}$ & $\begin{array}{c}\text { Potential } \\
\text { Growth }\end{array}$ \\
\hline & & \multicolumn{2}{c}{ Million gallons of ethanol } \\
IA - New England & CT, MA, ME, NH, RI, VT & 687 & 498 & 189 \\
IB - Central Atlantic DC, DE, MD, NJ, NY, PA & 1,860 & 1,122 & 738 \\
IC - Lower Atlantic & FL, GA, NC, SC, VA, WV & 2,539 & 488 & 2,051 \\
IIA - Midwest & IL, IN, KY, MI, OH, TN & 2,413 & 1,503 & 910 \\
IIB - Upper Plains & MN, ND, SD, WI & 609 & 482 & 127 \\
IIC - Lower Plains & IA, KS, MO, NE, OK & 903 & 386 & 517 \\
III - Gulf Coast & AL, AR, LA, MS, NM, TX & 2,061 & 673 & 1,388 \\
IV - Rocky Mountain CO, ID, MT, UT, WY & 463 & 160 & 303 \\
V- West Coast & AK, AZ, CA, HI, NV, OR, WA & 2,461 & 1,441 & 1,020 \\
US Total & & 13,996 & 6,752 & 7,244 \\
\hline Adapt & & &
\end{tabular}

Adapted from: Denicoff (2007) and Energy Information Administration, 2009j. Updates by Energy Source.

Figure 1-5. Description of PADDs

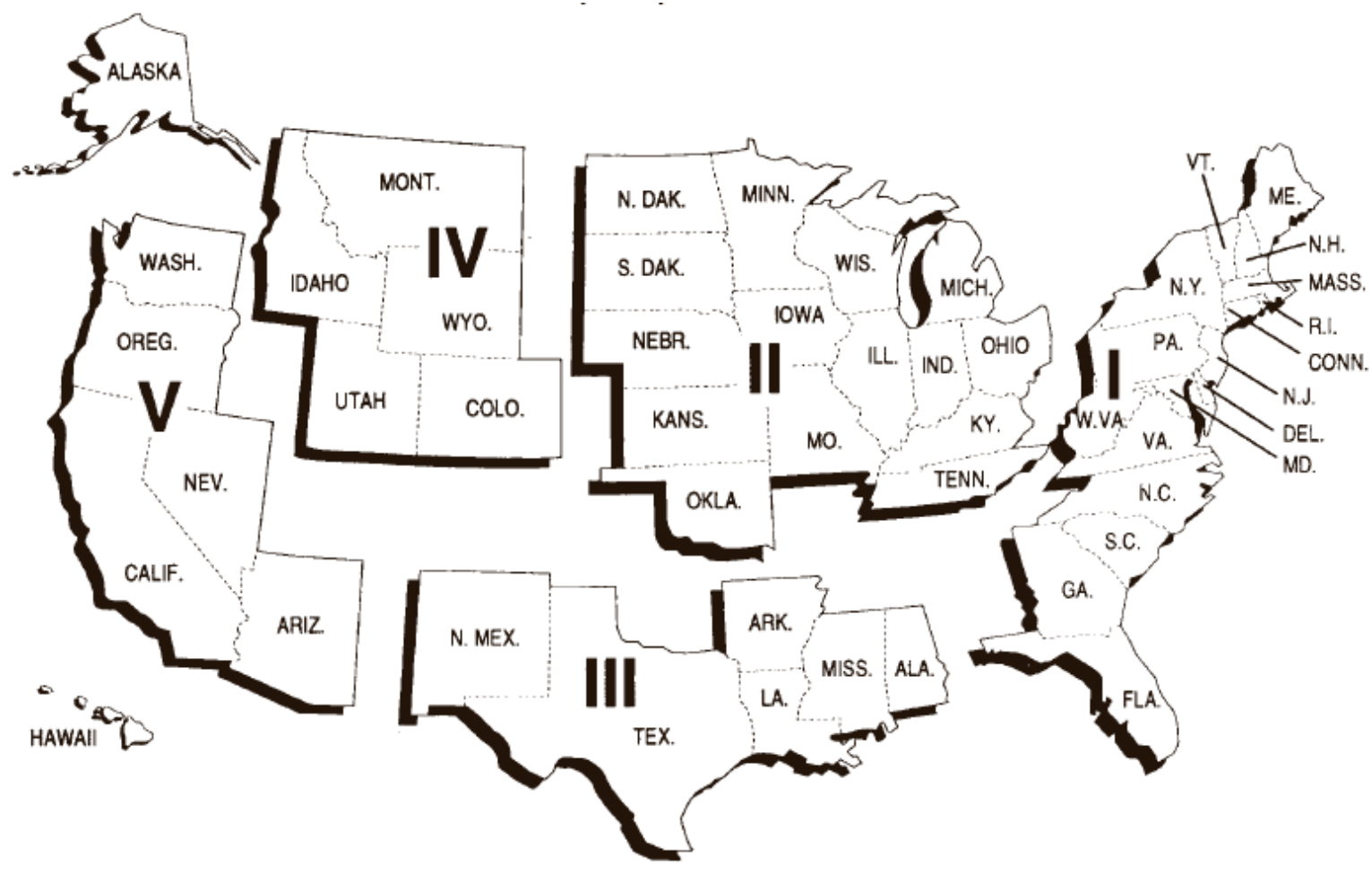


Debate continues over the levels of ethanol that can be blended into gasoline because of concerns over increasing emissions of nitrous oxide and because blending ethanol into gasoline raises Reid Vapor pressures, causing fuel to evaporate (Muehlegger, 2006). In November 2008, the EPA raised the renewable fuel standard to 10.21 percent blend of ethanol which leads to the use of 11.1 billion gallons of ethanol, up from 7.76 percent blend rate in November 2007 (EPA, 2008). During the hearings, the National Petrochemical \& Refiners Association argued that the mandate is impossible to meet given various infrastructure and technical barriers (Drevna, 2008). A GAO report questions whether the DOE has considered issues related to infrastructure to serve a larger ethanol market (Gaffigan, 2007).

While 14 BGY of ethanol is a good approximation for the use of ethanol as E10, the usage of ethanol varies by region (Table 1.3). The US gasoline market consists of reformulated and conventional gasoline (Figure 1-6). The difference between the two types is that reformulated gasoline is blended to meet EPA regulations per the Clean Air Act.

Figure 1-6. Map of Reformulated Gasoline, 2006

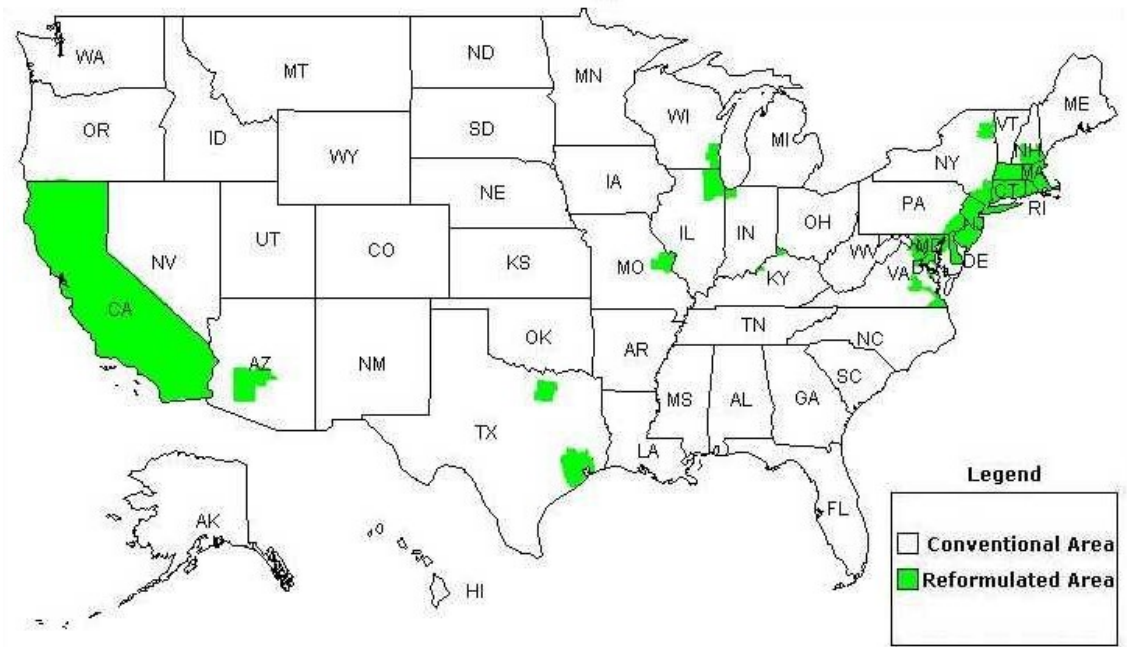

Source: Energy Information Administration, 2007b. Map of Reformulated Gasoline. 
Nationwide in 2008 , around $35 \%$ or 1 billion barrels of gasoline was reformulated, most of which $(99.4 \%)$ was blended with ethanol (Table 1.4). On the East and West Coasts over $63 \%$ of the gasoline is reformulated, while $20 \%$ is reformulated in the Midwest, $11 \%$ in the Gulf Coast, and none in the Rocky Mountains. Nationwide, $46.0 \%$ of the conventional gasoline was also blended with ethanol. This was especially true for the East Coast and the Midwest (PADD II), in part because ethanol's readily available. Large portions of the country, especially in the Southeast and Gulf Coast, adapted ethanol on a widespread basis in 2008.

Table 1.4. US Gasoline Consumption by Type, and Proportion Blended with Ethanol, 2008

\begin{tabular}{|c|c|c|c|c|c|c|}
\hline \multirow[b]{2}{*}{ PADD } & \multicolumn{3}{|c|}{ Type of Finished Motor Gasoline } & \multicolumn{3}{|c|}{ Proportion Blended with Ethanol } \\
\hline & \multicolumn{2}{|c|}{$\begin{array}{r}\text { Reformulated Conventional } \\
\text { Thousand barrels }\end{array}$} & All Gas & \multicolumn{2}{|c|}{$\begin{array}{c}\text { Reformulated Conventional } \\
\text { Percent }\end{array}$} & All Gas \\
\hline I- East Coast & 435,695 & 253,406 & 689,101 & $100.0 \%$ & $93.9 \%$ & $97.8 \%$ \\
\hline II - Midwest & 136,366 & 553,409 & 689,775 & $100.0 \%$ & $86.8 \%$ & $89.4 \%$ \\
\hline III-Gulf Coast & 135,128 & 921,140 & $1,056,268$ & $97.9 \%$ & $5.8 \%$ & $17.6 \%$ \\
\hline IV - Rockies & 0 & 109,359 & 109,359 & $0.0 \%$ & $40.6 \%$ & $40.6 \%$ \\
\hline V-West Coast & 385,359 & $\underline{142,528}$ & $\underline{527,887}$ & $99.2 \%$ & $\underline{66.5 \%}$ & $\underline{90.4 \%}$ \\
\hline US Total & $1,092,548$ & $1,979,842$ & $3,072,390$ & $99.4 \%$ & $46.0 \%$ & $65.0 \%$ \\
\hline
\end{tabular}

Source: Energy Information Administration, 2009h. Refinery \& Blender Net Production.

\subsection{Ethanol Supply}

Long range projections of ethanol capacity have been made by the Economic Research Service of the US Department of Agriculture (USDA) and the Energy Information Administration of the US Department of Energy (DOE). The DOE projected ethanol production through 2030 for both corn based ethanol and cellulosic based ethanol, while the USDA projection is for ten years for corn based ethanol. 
The DOE projects that ethanol production will rapidly expand from 2007 through 2010, at which time it will reach $12.8 \mathrm{BGY}$, all from domestic corn mills (Figure 1-7). Over the next 20 years, ethanol will expand to reach 29.3 BGY. DOE projections see cellulosic ethanol production of 5.1 BGY in 2030, well below provisions of the Renewable Fuels Standards. Nevertheless, the DOE forecast assumes that a scientific breakthrough occurs that allows for production of cellulosic ethanol on a commercial scale. The DOE also projects imports to increase from 0.7 BGY in 2006 to 7.5 BGY by 2030. Compared to the DOE, the USDA forecast anticipates less expansion in ethanol production from corn through 2010, reaching a peak of 13.6 BGY. Both reports indicate that the current construction frenzy will continue until 2010. After this, expansion likely will return to the slow growth seen during the 1990s (Figure 1-4).

Figure 1-7. USDA and DOE Forecasts of Ethanol Production and Imports, 2007 to 2030

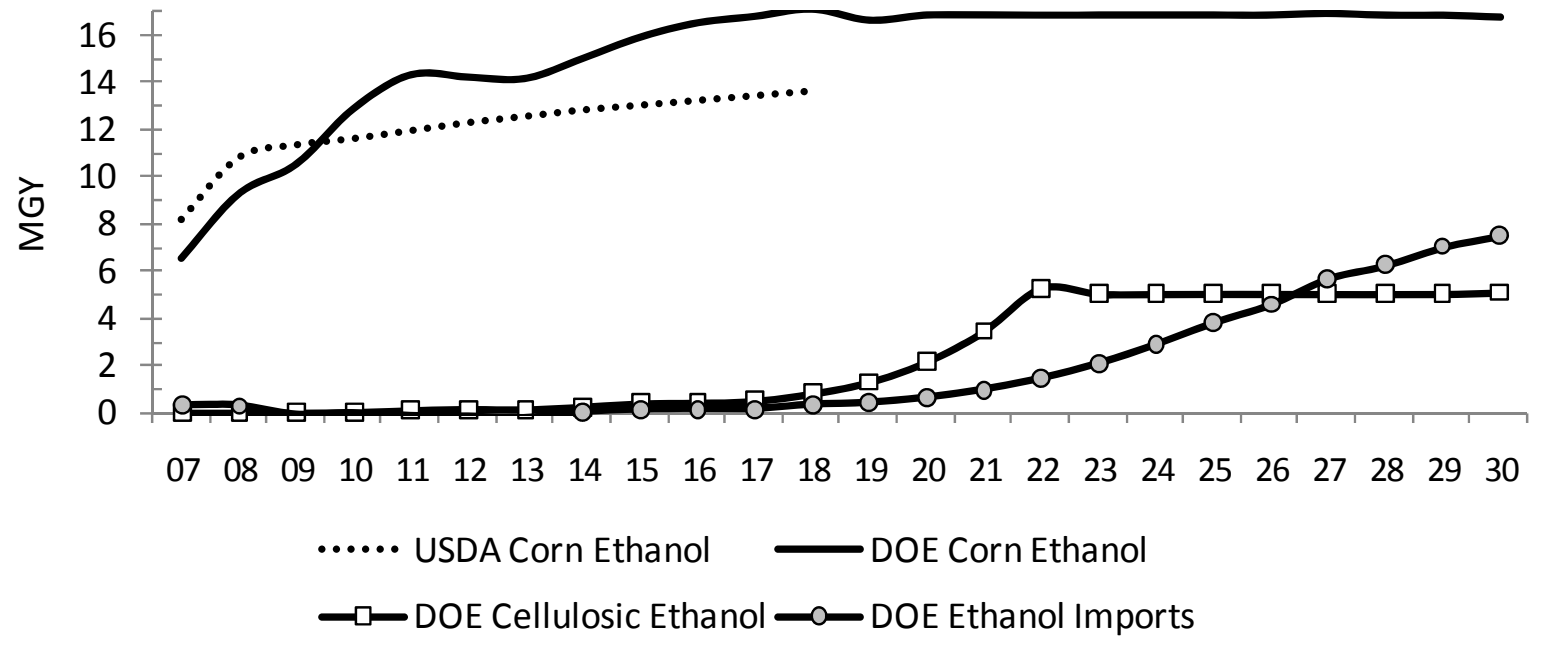

SOURCES: Energy Information Administration, 2009b and Westcott, 2009.

Keeping track of industry capacity has been a challenge given the explosive growth. Ethanol industry capacity numbers are reported by at least three entities (Table 1.5.) Lists of 
Table 1.5. Ethanol Capacity and Number of Plants, by Association, Spring 2009

\begin{tabular}{l|cc|cc|rc}
\hline \multirow{2}{*}{ Reporting Association } & \multicolumn{2}{|c|}{ Current Capacity } & \multicolumn{2}{c|}{ Idle Capacity } & \multicolumn{2}{c}{ Expansion } \\
\cline { 2 - 7 } & $\begin{array}{r}\text { No. of } \\
\text { Plants }\end{array}$ & $\begin{array}{c}\text { Capacity } \\
\text { (MGY) }\end{array}$ & $\begin{aligned} \text { No. of } & \text { Capacity } \\
\text { Plants } & \text { (MGY) }\end{aligned}$ & $\begin{array}{r}\text { No. of } \\
\text { Plants }\end{array}$ & $\begin{array}{c}\text { Capacity } \\
\text { (MGY) }\end{array}$ \\
\hline Renewable Fuels Assn $^{1}$ & 195 & 12,657 & 28 & 2,116 & 23 & 1,887 \\
Ethanol Producer Magazine $^{2}$ & 207 & 12,751 & 38 & 2,331 & 16 & 1,473 \\
Nebraska Energy Statistics $^{3}$ & 180 & 11,223 & 16 & 969 & 27 & 2,289 \\
\hline
\end{tabular}

${ }^{1}$ www.ethanolrfa.org/industry/locations (May 2009)

2 ethanolproducer.com/plant-list.jsp (May 2009)

${ }^{3}$ http://www.neo.ne.gov/statshtml/122.htm (March 2009)

plants are maintained by the state of Nebraska, the Renewable Fuels Association, and the emagazine, Ethanol Producer. There is general agreement among the three sources that industry capacity during Spring 2009 is around 12.6 BGY at 200 plants. Capacity utilization is around $86 \%$, meaning that roughly $1.7 \mathrm{BGY}$ of capacity is currently idle. These numbers also include 15 to 20 plants that process a feedstock other than corn, such as cheese whey or brewery waste. Typically, these other plants are very small compared to corn ethanol plants.

The expansion in ethanol capacity will exceed the ramp up in Renewable Fuels Standards for the next few years. The rapid expansion in ethanol capacity may be outpacing the ability of the market to absorb the product. In turn, this is leading to short term concerns of industry overexpansion. Ethanol Producer reports that 38 plants with a capacity of 2.3 BGY are shut down in May 2009. However, given the requirements of the Renewable Fuels Standards, this capacity will eventually be needed.

Operating and idled corn ethanol plants were divided into two groups, 83 plants built before 2006 (Old) and 110 plants built since 2006 (New). The median size New is slightly larger than the Old plant, at 57.3 MGY versus 48.0 MGY (Figure 1-8). The New plants are near the size 
Figure 1-8. Size Distribution of Ethanol Plants, 2009

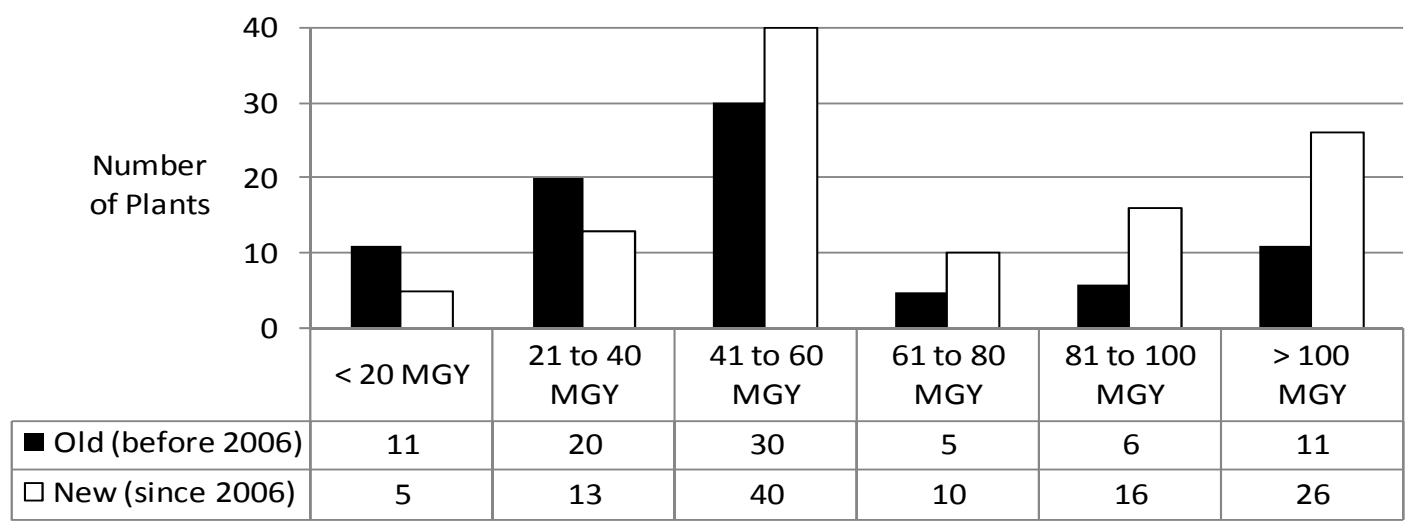

Calculated using data from: Ethanol Producer Magazine and Nebraska Energy Statistics

that achieves minimum operating cost on a basis of economies of size (Gallagher et al., 2007). Around $73 \%$ of the Old plants are less than $60 \mathrm{MGY}$. In contrast, over $47 \%$ of the New plants have more than 60 MGY of capacity. Thus, newer plants are being sized on the basis of economics while older plants were sized on the basis of subsidy programs. This implies that the newer plants will have larger draw areas for inbound transportation of corn.

In May 2009, most of the corn ethanol industry capacity was concentrated in PADD 2, or the Corn Belt and Great Plains states. Combined, these states US have $91 \%$ of the US corn ethanol built capacity, or 13.0 billion gallons. A total of 25 states currently produce ethanol. lowa leads the nation in ethanol capacity, with 3.5 BGY of current capacity (Figure 1-9). Other major ethanol producing states include Nebraska, Illinois, Minnesota, South Dakota, and Indiana. As of May 2009, 82 percent of industry corn ethanol capacity is operating. 
Figure 1-9. Built and Operating Capacity for Corn Ethanol Plants, by State, 2009

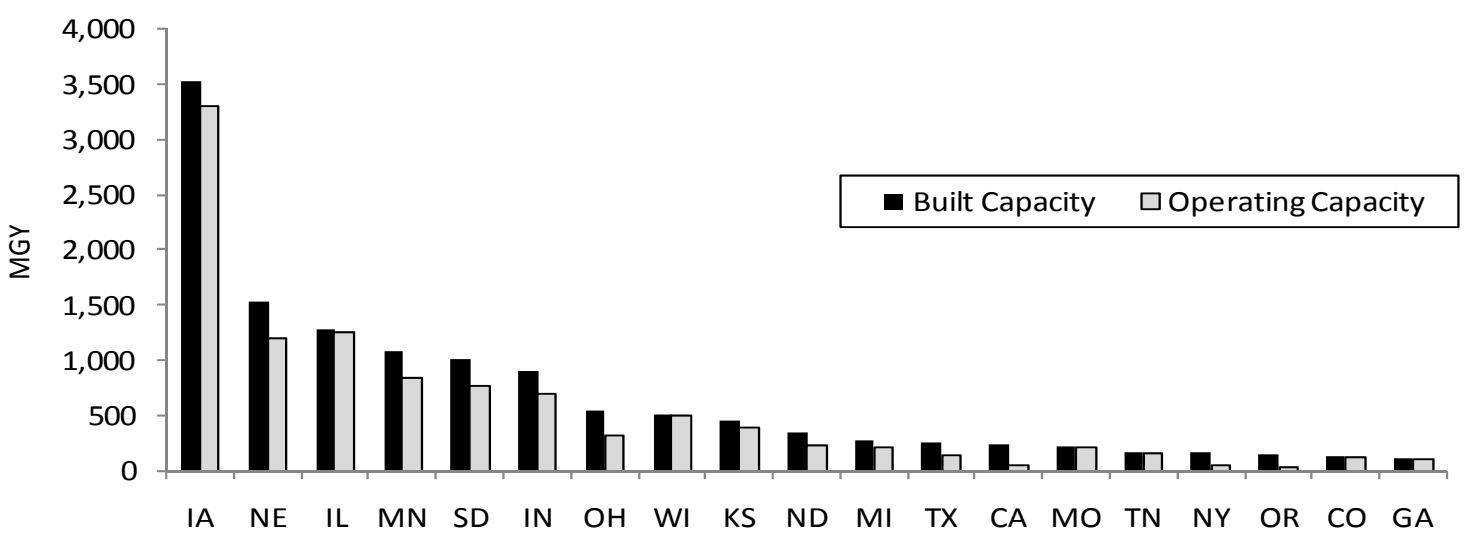

Calculated using data from: Ethanol Producer Magazine and Nebraska Energy Statistics.

\subsection{U.S. Biodiesel Market}

Compared to ethanol, biodiesel is in an early phase of market development in the USA, although it is widely adopted in Europe. The proportion of biodiesel blended into diesel has risen from virtually nil in 2001 to $0.6 \%$ in 2008 (Table 1.6). The 320 million gallons of biodiesel consumed in the US in 2008 is expected to grow to 1 billion gallons (Biomass Research and Development Board, 2009). Tax subsidies rules changed in March 2009 to discourage the practice of "splash and dash" or adding small amounts of diesel to imported biodiesel and then exporting the shipment, most likely to Europe (Energy Information Administration, 2009c).

Biodiesel is "composed of mono-alkyl esters of long-chain fatty acids derived from vegetable oils or animal fats" (National Biodiesel Board, 2007). A variety of inputs can be used as feedstock for biodiesel, including vegetable oils (soy, rapeseed, palm oil, etc.) and yellow grease (tallow and animal fats, or restaurant waste and trap grease). "The properties of the biodiesel (cloud point, pour point, and cetane number) depend on the type of feedstock used" 
Table 1.6. Diesel and Biodiesel Production, 2001 to 2008

\begin{tabular}{lrrrr}
\hline Year & Diesel Sold in the US & $\begin{array}{c}\text { US Biodiesel } \\
\text { Production }\end{array}$ & $\begin{array}{c}\text { US Biodiesel } \\
\text { Consumption }\end{array}$ & $\begin{array}{r}\text { Biodiesel Consumed } \\
\text { as a \% of Diesel Sold }\end{array}$ \\
\hline & \multicolumn{1}{c}{ Million gallons per year } & & \\
2001 & 45,119 & 8.6 & 10.2 & $0.02 \%$ \\
2002 & 44,145 & 10.5 & 16.2 & $0.04 \%$ \\
2003 & 45,635 & 14.2 & 13.5 & $0.03 \%$ \\
2004 & 47,186 & 28.0 & 26.9 & $0.06 \%$ \\
2005 & 49,153 & 90.8 & 90.8 & $0.18 \%$ \\
2006 & 52,544 & 250.4 & 260.6 & $0.50 \%$ \\
2007 & 55,296 & 489.8 & 358.2 & $0.65 \%$ \\
2008 & 53,316 & 682.5 & 320.2 & $0.60 \%$ \\
\hline
\end{tabular}

${ }^{1}$ Energy Information Agency, 2009f, Prime Supplier Sales Volumes.

${ }^{2}$ Energy Information Agency, 2009c, Biodiesel Supply and Consumption.

(Energy Information Administration, 2007b). Clean air regulations have led to a new generation of engines using ultra low-sulfur diesel, which in turn leads to a demand for biodiesel because of its high lubricity. Engine manufacturers specify acceptable blends, but most equipment can run $\mathrm{B} 5$ or a $5 \%$ blend of a biodiesel with diesel.

Soybeans are the most common feedstock in the US, with over 70 percent of biodiesel (Gray, 2006). A difference with ethanol is that soybean oil is a co-product of the milling process. Thus, until volumes of biodiesel reach around 500 MGY per year, the feedstock supply is plentiful. Like ethanol, usage varies on a regional basis. "The cloud and pour points for biodiesel are higher than those for petroleum diesel" which means that at cold temperatures the fuel can gel and clog fuel lines (Radich, 2007).

The nation's biodiesel capacity in May 2009 totaled 3.2 BGY (Table 1.7). This included 138 plants with 2.29 BGY of operating capacity, 47 plants with 596 MGY of idle capacity, and 14 
Table 1.7. Biodiesel Plant Capacity, By PADD, 2009

\begin{tabular}{llrrrr}
\hline PADD & \multicolumn{1}{c}{ States } & Operating & Idle & Construction & \multicolumn{1}{c}{ Total } \\
\hline & & \multicolumn{1}{c}{ Million gallons of biodiesel } & \\
IA - New England & ME, NH, RI, VT & 6.2 & 0.0 & 3.0 & 9.2 \\
IB - Central AtI & DE, MD, NJ, NY, PA & 203.5 & 6.0 & 110.0 & 319.5 \\
IC - Lower Atlantic & FL, GA, NC, SC, VA, WV & 167.4 & 36.0 & 11.2 & 214.6 \\
IIA -Midwest & IL, IN, KY, MI, OH, TN & 437.0 & 153.0 & 2.0 & 592.0 \\
IIB - Upper Plains & MN, ND, SD, WI & 190.6 & 8.0 & 3.0 & 201.6 \\
IIC- Lower Plains & IA, KS, MO, NE, OK & 504.9 & 61.0 & 15.0 & 580.9 \\
III - Gulf Coast & AL, AR, LA, MS, NM, TX & 642.1 & 209.0 & 7.0 & 858.1 \\
IV - Rocky Mtn & CO, ID, WY & 22.0 & 10.0 & 16.8 & 48.8 \\
V- West Coast & AK, AZ, CA, HI, NV, WA & 120.1 & 113.4 & 112.0 & 345.5 \\
US Total & & $2,293.8$ & 596.4 & 280.0 & $3,170.2$
\end{tabular}

Adapted from: Biodiesel Magazine.

plants with 280 MGY of new construction. The Energy Independence and Security Act of 2007 calls for 1 billion gallons of biodiesel as part of the RFS mandate. Thus, the current biodiesel capacity of 3.2 BGY suggests severe excess capacity (Yacobucci and Capehart, 2008).

Compared to ethanol, biodiesel production is widespread across the US, with plants in 45 states. PADD 2 only accounts for $43 \%$ of the nation's total biodiesel production as opposed to 91 percent of the nation's ethanol capacity (Table 1.7). The top 10 states in terms of productive capacity are Texas, lowa, Alabama, Illinois, Missouri, New York, Ohio, Indiana, and Mississippi, accounting for 62 percent of productive capacity.

Biodiesel plants are typically much smaller than ethanol plant, with a median sized plant of $6 \mathrm{MGY}$ and an average sized plant of 15.9 (Figure 1-10). The 149 biodiesel plants that can use soy oil as a feedstock are twice as large as the $\mathbf{5 0}$ other plants using other feedstock, with a median size of 10.0 versus $5.0 \mathrm{MGY}$. 
Figure 1-10. Size Distribution of Biodiesel Plants, 2009

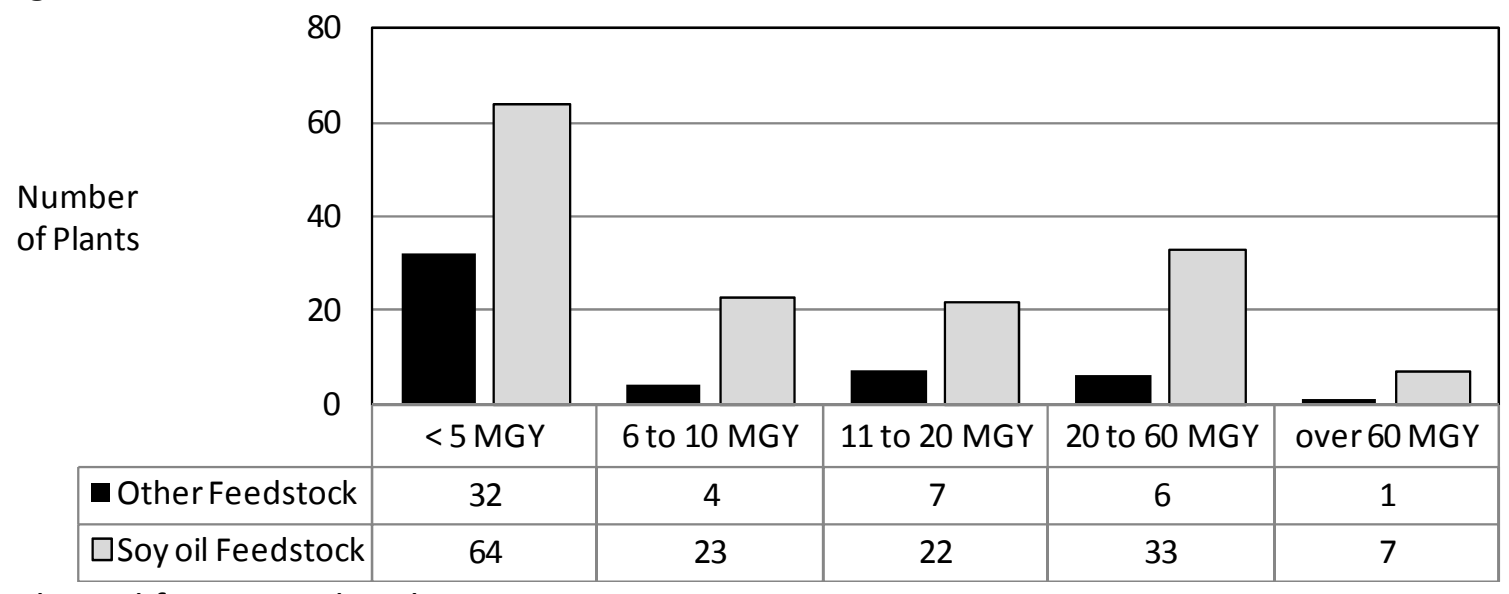

Adapted from: Biodiesel Magazine.

The USDA and DOE also have long-run forecasts for biodiesel production. The USDA forecast is only for the use of soy oil to produce methyl esters (or biodiesel), while the DOE forecast includes all forms of biodiesel. The USDA forecast is a relatively flat for the next decade, at roughly 430 million gallons per year (Figure 1-11). The DOE forecast is much higher than the USDA forecast as early as 2010 , in part to reach the goals of the RFS (Figure 1-1). The production of biodiesel beyond the 1.0 billion gallon level is considered part of the advanced biofuels requirement.

\subsection{Corn and Soybean Utilization}

The demand for corn swells with increases in production of ethanol. In 2008, about 3.75 billion bushels of corn was used for ethanol production, or about 31\% of the 2008 U.S. corn crop (Figure 1-12). The future effects of this growth are unknown but might include increasing corn prices, an expansion in corn acreage, less corn fed to livestock, or less corn available for export. USDA projections for total usage of U.S. corn are to rise from 14.1 billion bushels in 2008 to 16.5 billion bushels a decade later. Feed, food, and export uses are constant at around 5.8, 1.4, 
Figure 1-11. USDA and DOE Forecasts of Biodiesel Production

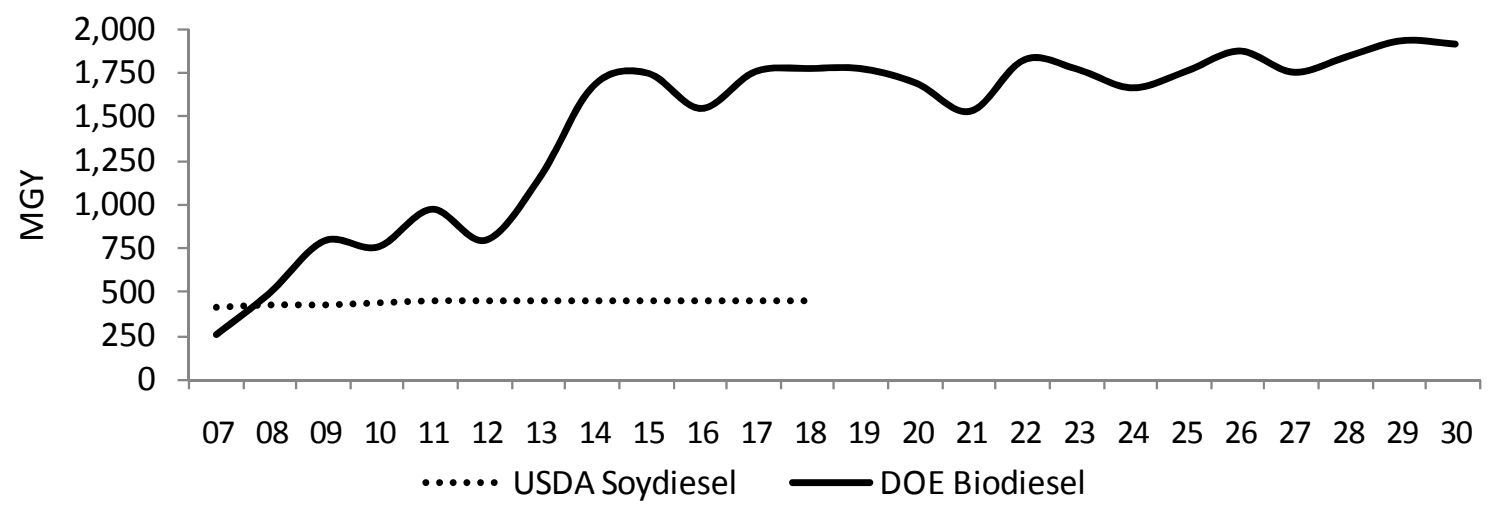

SOURCES: Energy Information Administration, 2009b and Westcott, 2009.

and 2.2 billion bushels, respectively. In contrast, the USDA estimates that 5.1 billion bushels of corn will be used to produce ethanol by 2018 , or 35 percent of production. However, the use of corn to produce ethanol increases only about 100,000 bushels per year over the next decade as opposed to an increase of almost 2 billion bushels from 2006 to 2009.

Unlike corn, soybean utilization is forecast to be relatively stable over the next decade (Figure 1-13). Soybean crush will increase from 1.6 billion bushels in 2008 to 1.9 billion bushels in 2018, while exports will be flat. The usage of soybeans for biodiesel is forecast to rise to roughly 250 million bushels per year, or around 16 percent of the domestic oil crush, but then remain relatively flat.

Historically, corn and soybean production are interrelated. Thus, changes in corn production have had an effect on soybean production and vice versa. Throughout much of the past decade corn and soybean harvested acres have seen little volatility (Figure 1-14). In 2007, 
Figure 1-12. Corn Utilization for Feed, Food, Exports, and Ethanol, 2001 to 2018

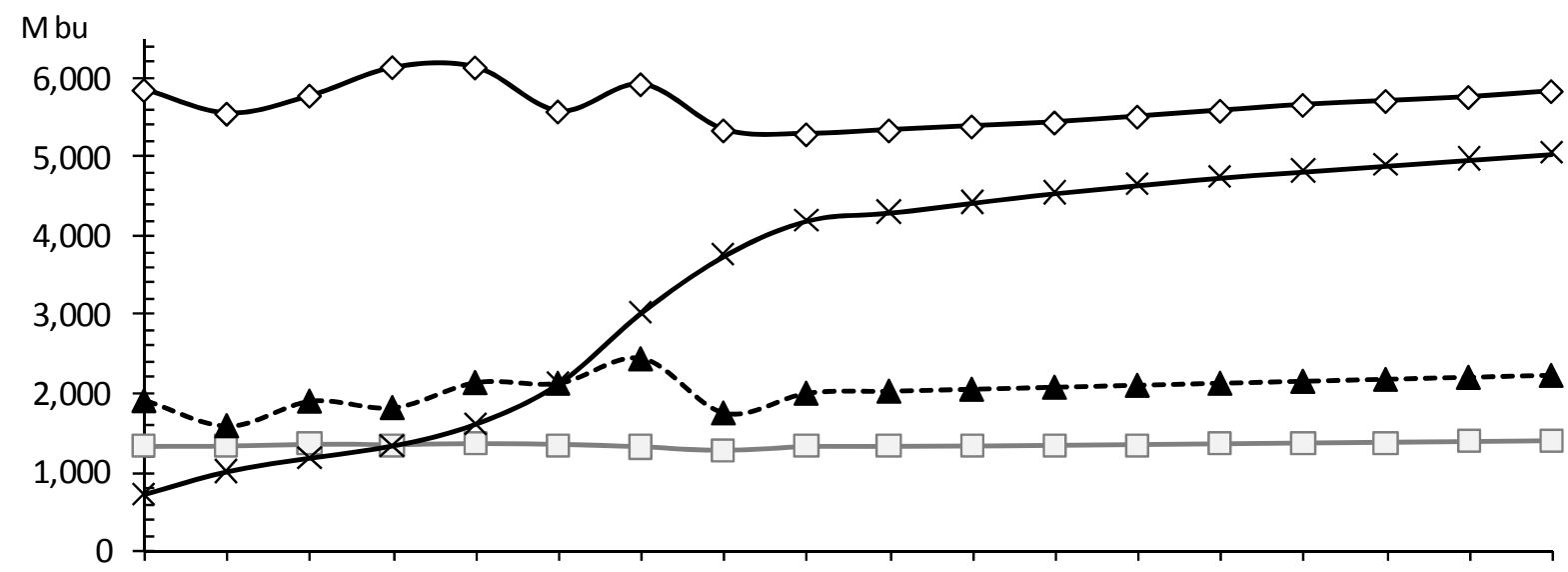

200120022003200420052006200720082009201020112012201320142015201620172018 $\sim$ Feed $\square-\square$ Food --A-- Exports $\rightarrow$ Ethanol

Source: United States Department of Agriculture (2009b) and Westcott (2009).

Figure 1-13. Soybean Utilization for Crush, Seed, Biodiesel and Exports, 2001 to 2018

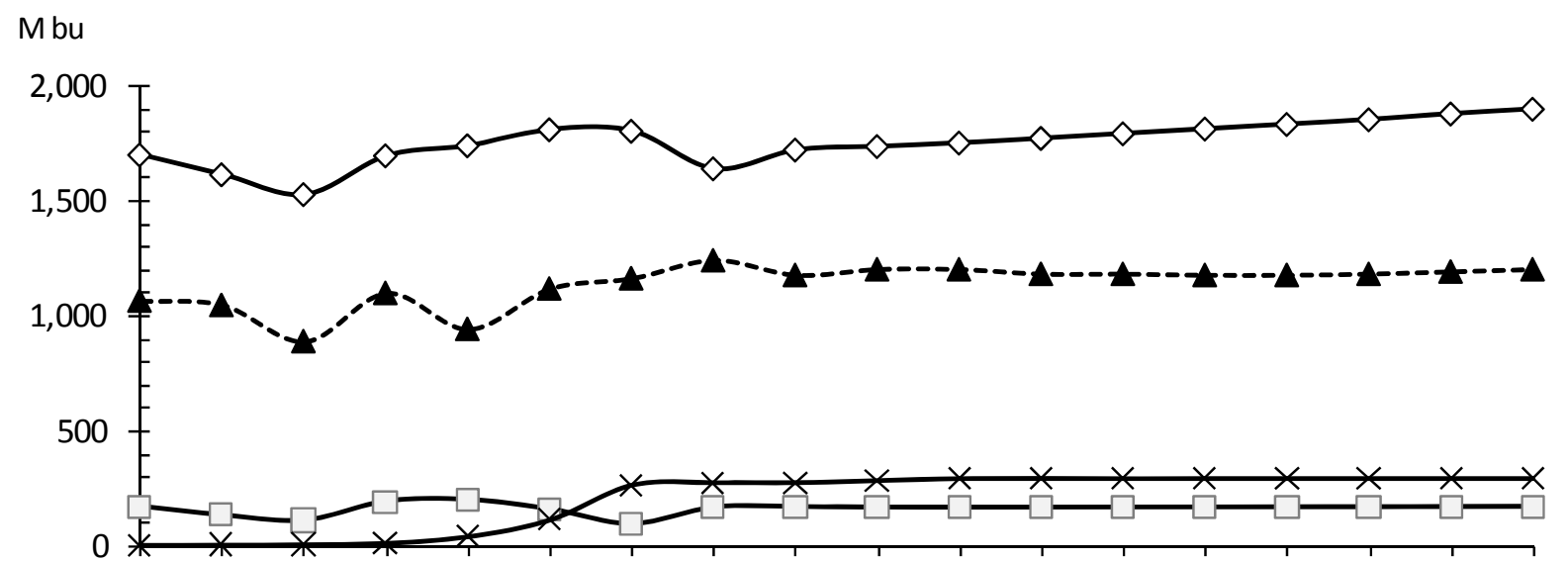

200120022003200420052006200720082009201020112012201320142015201620172018

$$
\sim \text { Crush } \square-\text { Seed --A--Exports } \multimap \text { Biodiesel }
$$

Source: United States Department of Agriculture (2009b) and Westcott (2009). 
Figure 1-14. Corn and Soybean Harvested Acres in United States, 1990-20087

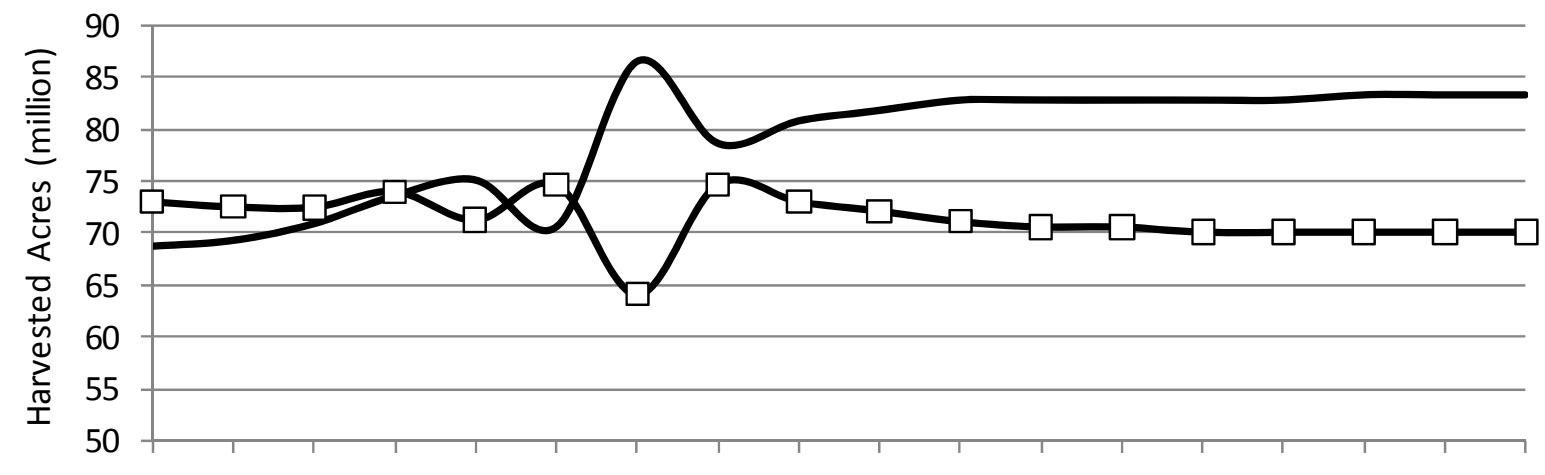

200120022003200420052006200720082009201020112012201320142015201620172018

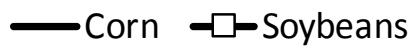

Source: United States Department of Agriculture (2009b) and Westcott (2009

this trend deviated with a sharp increase in corn acres and decrease in soybean acres. This change can be explained partially in an increase in ethanol demand as well as in corn price. USDA forecasts assume that the volatility in harvested acres of corn and soybeans will diminish over the next decade. Compared to the past decade, corn acreage will increase, while soybean acreage will slightly decrease.

\subsection{DDGS}

The production of ethanol creates a co-product called distillers dried grains and solubles (DDGS), which is commonly sold as a livestock feed source. DDGS is produced after the starch portion of corn is converted to ethanol and carbon dioxide leaving components of protein, fat, fiber, vitamins and minerals which are then concentrated and dried to produced DDGS. DDGS is more valuable as a feed in ruminant animals (cattle and sheep) because rations fed to monogastric livestock (swine and poultry) must add several synthetic amino acids (Urbanchuk 2003). 
DDGS is used as a feed supplement, meaning it cannot be considered a primary feed source in livestock feed rations. The percentage of DDGS in the diet varies among livestock species ranges from 20 percent for sheep and beef cattle rations, dairy cattle can consume up to 25 percent DDGS, while poultry and hogs can only consume 10 percent of DDGS in a ration.

Historically, DDGS has been an important source of revenue for an ethanol plant. A study examining profit margins for a 40 million gallon ethanol plant, found $15 \%$ to $20 \%$ of the plant's revenue was from DDGS sales (Tiffany and Eidman, 2003). Due to the increase in ethanol prices coupled with payments through tax incentives, the percent of plant revenue in 2007 from DDGS sales fell to approximately 10\% (McElroy 2006). However, as ethanol prices fell in late 2008 , DDGS once again became important plant revenue stream.

Advantages of DDGS as a feed supplement include high protein content, high available phosphorus, high fiber content, and substitutability (Matthews and McConnell, 2009). However, DDGS has its disadvantages as well, including supplementation, high nitrogen uptake, nutrition composition, quality consistency, transportation, and market volumes. The lack of consistency in DDGS production among differing plants and batches within a particular plant is seen as a key detriment. Variations in nutrient content cause livestock producers to use less DDGS as a supplement. For example, fat content has been found to range from $1 \%$ to $30 \%$, protein from $24 \%$ to $29 \%$, and moisture $9 \%$ from $15 \%$ (McElroy 2006 ).

"The biggest obstacle to providing co-products to livestock feeders is transporting the feeds from the processing plant to the livestock feeding operation" (Matthews and McConnell, 2009). For example, the Burlington Northern Santa Fe and Union Pacific, two of the nation's largest railroads, have banned hauling DDGS in their own equipment, although they will 
transport DDGS loaded in shipper owned cars (Cooper, 2005). Transportation difficulties can arise unless DDGS is properly manufactured, as it can become difficult to unload from hopper rail cars due to caking occurring during transport. Segregation of particles also occurs during handling and transportation, adding to the already existing quality and consistency issues.

As a co-product of ethanol, DDGS production tracks the explosive growth in ethanol capacity. Each bushel of corn yields 2.81 gallons of denatured ethanol and 16.58 pounds of DDGS (Wu, 2008). Given projections for corn used to produce ethanol (Figure 1-12), DDGS production was 31.09 million tons in 2008 and will climb to 40 million tons by 2015 . Roughly 24.2 million tons of DDGS was consumed domestically in 2008, with the remainder being exported (Dooley, 2008b).

\subsection{Production of Biofuels in Indiana}

Ethanol has been produced by New Energy in South Bend since 1985 at a 100 million gallon per year (MGY) plant (Table 1.8). In 2007, five plants opened adding 355 MGY, while four more plants opened an additional 335 MGY in 2008. As of March 2009, 9 plants around the state have the capacity to produce 690 million gallons of ethanol. Plants at Cloverdale and Linden are currently shutdown, idling $140 \mathrm{MGY}$, because of firm bankruptcies. An additional $198 \mathrm{MGY}$ is under construction by two different firms near Mount Vernon. The Indiana ethanol industry can produce 2.035 million tons, with the potential for another 997,000 tons from the idle plants and plants under construction.

The biodiesel plant at Claypool, Indiana that opened in January 2008 is among the seven largest plants in the U.S, with 88 MGY of capacity (Table 1.9). Other operating biodiesel plants 
Table 1.8. Indiana Ethanol Plants, by Year, Location, and Capacity, March 2009

\begin{tabular}{|c|c|c|c|c|c|}
\hline \multirow{2}{*}{ Company } & \multirow{2}{*}{ Year } & \multirow{2}{*}{ City/County } & \multicolumn{3}{|c|}{ Million Gallons } \\
\hline & & & Operating & Idle & Construction \\
\hline New Energy. & 1985 & South Bend/St. Joseph & 100 & & \\
\hline Iroquois Bio-Energy & 2007 & Rensselaer/Jasper & 40 & & \\
\hline The Andersons & 2007 & Clymers/Cass & 110 & & \\
\hline Central Indiana Ethanol & 2007 & Marion/Grant & 40 & & \\
\hline POET & 2007 & Portland/Jay & 65 & & \\
\hline VeraSun/ West LB & 2007 & Linden/Montgomery & & 100 & \\
\hline POET & 2008 & Alexandria/Madison & 60 & & \\
\hline Altra & 2008 & Cloverdale/Putnam & & 60 & \\
\hline POET & 2008 & N Manchester/Wabash & 65 & & \\
\hline Indiana Bio-Energy & 2008 & Bluffton/Wells & 110 & & \\
\hline Cardinal Ethanol & 2008 & Harrisville/Randolph & 100 & & \\
\hline Abengoa Bioenergy & & Mt. Vernon/Posey & & & 88 \\
\hline Aventine Renewable & & Mt. Vernon/Posey & & & 110 \\
\hline \multicolumn{3}{|c|}{ Indiana Total Ethanol Capacity (million gallons) } & 690 & 140 & 198 \\
\hline \multicolumn{3}{|c|}{ Indiana Total DDGS Capacity (million tons) } & 2.035 & .413 & .584 \\
\hline
\end{tabular}

Source: Indiana State Department of Agriculture, 2009.

Table 1.9. Indiana Biodiesel Plants, by Year, Location, and Capacity, March 2009

\begin{tabular}{lccr}
\hline Company & Year & \multicolumn{1}{c}{ City/County } & Operating Capacity (MGY) \\
\hline Evergreen Renewables & 2006 & Hammond/Lake & 5 \\
Integrity Biofuels. & 2006 & Morristown/Shelby & 5 \\
E-biofuels & 2007 & Middletown/Henry & 10 \\
Louis Dreyfus & 2008 & Claypool/Kosciusko & 88 \\
Xenerga & 2008 & Kingsbury/LaPorte & $\underline{10}$ \\
Indiana Total Ethanol Capacity (million gallons) & 118 \\
\hline
\end{tabular}

Source: Indiana State Department of Agriculture, 2009.

in Indiana are found at Middletown (10 MGY), Hammond (5 MGY), Kingsbury (10 MGY), and Morristown (5 MGY). The Xenerga plant at Kingsbury is the only one that does not use soybeans as a feedstock. 


\subsection{Conclusions}

Since 2006, there have been major changes in corn and soybean production, grain marketing, and the like surrounding the expansion in biofuels production. If anything, Indiana appears to have seen more expansion than most states. At this point, it is likely that most of the changes in production have occurred. In other words, additional ethanol or biodiesel expansion is not anticipated in the next five years.

The changes that have take place over the past three years, however, have had profound ramifications for transportation in the state. The remainder of this report investigates the volume of these changes. 


\section{Chapter 2 .DATA, ASSUMPTIONS AND MODEL DEVELOPMENT}

This chapter discusses the data sources, key assumptions, and development of the model. The goal of the model is to compare and evaluate the effects that ethanol expansion will have on transportation requirements in Indiana. The model is developed for three time periods such that changes in transportation requirements can be determined before (2006), during (2008), and after (2010) ethanol expansion takes place in Indiana. Thus, the 2006 model served as a baseline model, which is compared with a short term adjustment model (2008), and a long term adjustment model (2010). The only changes between time periods are adjustments to corn and soybean production, the addition of ethanol and biodiesel plants, and changes in livestock consumption of corn as more DDGS is fed.

The biofuels capacity reflects reported operating capacities as of yearend for 2006 and 2008 (Table 1.8 and 1.9). In the long run (2010), all plants under construction are assumed to come online and idle capacity is assumed to reopen. Thus, the total production of ethanol rose from 100 to 690 million gallons of ethanol between 2006 and 2008, and in the long run is modeled to reach just over 1 billion gallons (Table 2.1).

Table 2.1. Assumed Indiana Ethanol and Biodiesel Capacity and Grain Requirements, by Year

\begin{tabular}{|c|c|c|c|c|c|c|c|}
\hline Year & $\begin{array}{l}\text { No. of } \\
\text { Ethanol } \\
\text { Plants }\end{array}$ & $\begin{array}{l}\text { Indiana } \\
\text { Ethanol } \\
\text { Capacity }\end{array}$ & $\begin{array}{c}\text { Corn } \\
\text { Required }\end{array}$ & $\begin{array}{c}\text { DDGS } \\
\text { Produced }\end{array}$ & $\begin{array}{c}\text { No. of } \\
\text { Biodiesel } \\
\text { Plants }\end{array}$ & $\begin{array}{c}\text { Indiana } \\
\text { Biodiesel } \\
\text { Capacity }\end{array}$ & $\begin{array}{l}\text { Soybeans } \\
\text { Required }\end{array}$ \\
\hline & & MGY & $\begin{array}{l}\text { million } \\
\text { bushels }\end{array}$ & $\begin{array}{l}\text { million } \\
\text { tons }\end{array}$ & & $\begin{array}{c}\text { million } \\
\text { bu. }\end{array}$ & $\begin{array}{l}\text { million } \\
\text { bushels }\end{array}$ \\
\hline 2006 & 1 & 100 & 35.59 & .29 & 2 & 10 & 6.71 \\
\hline 2008 & 9 & 690 & 245.55 & 2.045 & 5 & 118 & 79.19 \\
\hline 2010 & 13 & 1,048 & 372.95 & 3.09 & 5 & 118 & 72.19 \\
\hline
\end{tabular}


A bushel of corn is assumed to produce 2.81 gallons of denatured ethanol and 16.6 pounds of ethanol (Wu, 2008). Thus, the corn utilized to produce ethanol rose sevenfold from 2006 to 2008, from 35.6 to 245.6 million bushels (Table 2.1). With continued expansion of capacity, corn utilization for ethanol will rise to 372.9 million bushels in the long run. The production of DDGS tracks the expanded use of corn, rising from 295,000 tons in 2006 to 3.1 million tons long run.

A bushel of soybeans is assumed to produce 1.49 gallons of biodiesel (Gray, 2006). Thus, the use of soybeans to produce biodiesel is expected to increase from 6.7 to 79.2 million bushels as Industry capacity grows from 10 to 118 million gallons (Table 2.1).

The model determines transportation flows from each county level supply point to demand point for corn, soybeans, DDGS, and ethanol. To capture changes in transportation requirements over the three time periods, the model estimates total truck loads, average length of haul (LOH), total truck miles as measured by vehicle miles traveled (VMT), and rail carloads at a county level for commodity flows of corn, soybeans, ethanol, and DDGS. The change in truck loads, LOH, VMTs, and rail carloads across the three periods captures the effects that biofuels expansion has on transportation requirements.

Production data are collected at the county level for corn, soybeans, ethanol, and DDGS. The data are collected for all 92 counties in Indiana, as well as the 39 border counties in the adjacent states of Illinois, Michigan, Ohio, and Kentucky. Demand data are also collected at the county level for feeding livestock, food processing plants, soybean crushing facilities, ethanol and biodiesel plants, and grain elevators. Linear programming transportation models are used to allocate various commodities from supply points to demand points. 
Briefly the eight steps to estimate transportation requirements are:

1. Establish corn and soybean production for three time periods at the county level.

2. Establish livestock populations for ten species of livestock, and then estimate feed demand for DDGS. A linear programming transportation model is used to allocate available supplies of DDGS from ethanol plants to demand points.

3. Estimate county level feed demand for corn, after adjustments are made for feeding DDGS.

4. Estimate the transportation requirements (average trip, total truck loads, and VMT) required to supply livestock with corn and DDGS.

5. After livestock demand for corn is met, use a linear programming transportation model to allocate remaining corn to food processing and ethanol plants and Estimate transportation requirements to supply food processing and ethanol plants with corn. Allocate any remaining corn to country elevators; estimate transportation requirements for such movements.

6. Develop a linear programming transportation model to allocate soybeans to soybean crushing and biodiesel plants. Estimate transportation requirements to supply soybean crushers and biodiesel plants with soybeans. Like corn, allocate any remaining soybeans to country elevators; estimate transportation requirements for such movements.

7. Use a linear programming transportation model to allocate ethanol within the truck market area and estimate transportation requirements to supply ethanol to blending terminals. Remaining ethanol is assumed to be shipped by rail.

8. Allocate any remaining corn and soybeans from local county elevators to out-ofstate demands via truck and rail.

\subsection{Step 1 - Grain Production}

Data for county level corn and soybean yields and harvested acres were obtained from the National Agriculture Statistic Service (NASS) for the years 2005 to $2008 .{ }^{1}$ Data for 2010 adjusts 2008 values based on long term USDA forecasts (Westcott, 2009). Total crop production is

\footnotetext{
${ }^{1}$ County level data are available on "Statistics by State" portion of NASS website http://www.nass.usda.gov/Data and Statistics/Quick Stats/index.asp.
} 
calculated by multiplying harvested acres by the yield for each respective year and county. Crop production for 2006 is based on a two-year average of harvested acres and yields for 2005 and 2006, while 2008 data reflect the 2007 and 2008 crop years.

While total grain acres are relatively constant at 11.1 million acres over the three time periods, the last two time periods reflect a shift as more acres are planted to corn than beans (Table 2.2). Long run corn yields are expected to be 5 percent higher than the 2008 yields, while soybean yields are relatively stable. Thus, overall grain production is expected to climb from 1.14 to 1.18 to 1.25 billion bushels from 2006 to 2008 to 2010 , respectively.

Table 2.2. Indiana Corn and Soybean Production, by Year

\begin{tabular}{lrrr}
\hline Year & Corn & Beans & Total \\
\hline & & Acreage (1,000 acres) & \\
2006 & $5,575.0$ & $5,530.0$ & $11,105.0$ \\
2008 & $5,915.0$ & $5,110.0$ & $11,025.0$ \\
2010 & $5,911.4$ & $5,283.7$ & $11,195.1$ \\
& & Yield in Bushels per Acre & \\
2006 & 155.5 & 49.5 & \\
2008 & 157.0 & 45.5 & \\
2010 & 164.9 & 48.6 & \\
& & Production (million bushels) & \\
2006 & 866.9 & 277.3 & $1,143.2$ \\
2008 & 928.1 & 249.0 & $1,177.1$ \\
2010 & 974.0 & 275.0 & $1,249.0$ \\
\hline
\end{tabular}

SOURCES: National Agriculture Statistic Service (2009) and Westcott (2009).

\subsection{Step 2 - Livestock Feed Demand for DDGS}

Estimating livestock feed demand for DDGS requires data for animal numbers and assumed feeding rates. Livestock numbers by county for each of ten species were obtained from the 
2007 Census of Agriculture (United States Department of Agriculture, 2009a). Species included in livestock numbers are dairy cows, beef cows, other cattle, cattle on feed, breeding swine, market swine, broilers, layers, pullets, and turkeys (Table 2.3). Numbers of animals in Indiana from the Census are assumed to be constant for all three time periods (Table 2.4).

Table 2.3. Definitions of Livestock Species

\begin{tabular}{|c|c|c|}
\hline Specie & Definition & $\begin{array}{l}\text { Size Classification } \\
\text { for Large Farms }\end{array}$ \\
\hline Dairy Cows & Breeding cows for milk and dairy production & $>100$ head \\
\hline Beef Cows & Breeding cows for beef production & $>100$ head \\
\hline Other Cattle & $\begin{array}{l}\text { Includes all heifers, heifer calves, steers, steer calves, } \\
\text { bulls, and bull calves }\end{array}$ & $>100$ head \\
\hline Cattle on Feed & $\begin{array}{l}\text { Cattle and calves being fed a grain or other concentrate } \\
\text { ration for slaughter market that will produce a carcass } \\
\text { that will grade select or better }\end{array}$ & All farms \\
\hline Breeding Swine & Swine produced for breeding purposes & $>1,000$ head \\
\hline Market Swine & Swine produced for market & $>1,000$ head \\
\hline Broilers & Chicks produced for market and meat consumption & $>60,000$ birds \\
\hline Layers & $\begin{array}{l}\text { Layer hens in molt and other layers and pullets of } 20 \\
\text { weeks old }\end{array}$ & $>20,000$ birds \\
\hline Pullets & $\begin{array}{l}\text { Chicks for layer hen replacement younger than } 20 \text { weeks } \\
\text { old }\end{array}$ & $>100,000$ birds \\
\hline Turkeys & All turkeys produced for slaughter or breeding & $>30,000$ birds \\
\hline
\end{tabular}

Source: National Agriculture Statistic Service, 2009.

While all livestock are assumed to eat corn, DDGS are only fed to livestock raised on larger sized farms (Dooley, 2008b). Thus, animal populations are also obtained for all livestock and livestock on large farms (Table 2.4). Size thresholds are defined in Table 2.3 for each species. The use of DDGS in animal rations is increasing, in part because of greater availability. 
Table 2.4. Animal Populations in Study Area, 2007

\begin{tabular}{l|rrr}
\hline \multirow{2}{*}{ Class of Livestock } & Small Farms & Large Farms & Total \\
\cline { 2 - 4 } Dairy Cows & Number of animals & & \\
\cline { 2 - 4 } Beef Cows & 67,447 & 178,762 & 246,209 \\
Other Cattle & 312,623 & 77,776 & 390,399 \\
Cattle on Feed & 329,433 & 409,466 & 738,899 \\
Breeding Swine & 0 & 179,403 & 179,403 \\
Market Swine & 60,620 & 325,478 & 386,098 \\
Broilers & 470,749 & $4,044,796$ & $4,515,545$ \\
Layers & $18,698,054$ & $39,350,741$ & $58,048,795$ \\
Pullets & $3,691,460$ & $40,372,868$ & $44,064,328$ \\
Turkeys & $1,602,357$ & $9,576,237$ & $11,178,594$ \\
\hline
\end{tabular}

Source: National Agriculture Statistic Service, 2009.

For the 2006 and 2008 scenarios, the DDGS feeding rate is based on a NASS (2007) survey of livestock feeding practices (Table 2.5). In the long run, DDGS inclusion rates are expected to rise as farmers become more familiar with feeding DDGS. Thus, the DDGS feeding rate for 2010 is based on work by Berger and Good (2007), who summarized the literature for DDGS consumption for dairy, cattle, hogs, and poultry.

The county level feed demand for DDGS is determined as:

2-1. DDGSFed $_{\mathrm{i}, \mathrm{s,t}}=\sum_{\mathrm{s}}$ LargeFarmHerd $_{\mathrm{i}, \mathrm{s}, \mathrm{t}} *$ Feed $_{\text {rate }} \mathrm{i}_{\mathrm{s}, \mathrm{t}}$

where: $i$ is the county of production, $S$ is the species of animal, and $\mathrm{t}$ is the time period, $\mathrm{t}=2006,2008,2010$.

The DDGS demand is calculated for each of the ten species (s), and is then summed to reach a county total. DDGS demand in Indiana counties is 289,266 tons in 2006 and 2008, and 824,919 tons in the long run. It is assumed that DDGS demand in Indiana is fulfilled via truck 
Table 2.5. DDGS and Corn Annual Feeding Rates per Head, by Species, by Year

\begin{tabular}{|c|c|c|c|c|c|}
\hline \multirow{2}{*}{$\begin{array}{l}\text { Class of } \\
\text { Livestock }\end{array}$} & \multicolumn{2}{|c|}{ DDGS Feeding Rate } & \multicolumn{3}{|c|}{ Corn Feeding Rate } \\
\hline & $\begin{array}{c}2006 \text { and } \\
2008^{a}\end{array}$ & $2010^{b}$ & $\begin{array}{c}\text { Corn } \\
\text { Alone }^{c}\end{array}$ & $\begin{array}{l}\text { Corn with DDGS } \\
\text { in } 2006 / 2008^{d}\end{array}$ & $\begin{array}{c}\text { Corn with } \\
\text { DDGS in } 2010^{d}\end{array}$ \\
\hline & \multicolumn{5}{|c|}{ (lbs/yr/head) } \\
\hline Dairy Cows & $1,002.00$ & $1,642.50$ & $5,824.0$ & $5,091.5$ & $4,623.3$ \\
\hline Beef Cows & 396.00 & 720.00 & $1,111.0$ & 637.4 & 249.9 \\
\hline Other Cattle & 346.50 & 630.00 & 862.9 & 448.5 & 109.4 \\
\hline Cattle on Feed & 916.00 & $2,555.00$ & $6,151.6$ & $5,056.1$ & $3,095.8$ \\
\hline Breeding Swine & 105.53 & 372.00 & $1,229.2$ & $1,135.3$ & 898.1 \\
\hline Market Swine & 51.77 & 182.50 & 574.0 & 527.9 & 411.6 \\
\hline Broilers & 0.33 & 1.16 & 6.3 & 6.0 & 5.3 \\
\hline Layers & 3.37 & 11.86 & 56.0 & 53.0 & 45.4 \\
\hline Pullets & 1.03 & 3.61 & 56.0 & 55.1 & 52.8 \\
\hline Turkeys & 1.80 & 6.36 & 59.4 & 57.8 & 53.7 \\
\hline
\end{tabular}

SOURCES:

${ }^{a}$ National Agricultural Statistics Service, 2007.

${ }^{\mathrm{b}}$ Berger and Good, 2007.

${ }^{\mathrm{C}}$ Quear, 2008.

${ }^{\mathrm{d}}$ Calculated.

with a capacity of 25 tons. Remaining DDGS after Indiana demand is fulfilled is transported out of the state via rail cars with a capacity of 100 tons (Denicoff, 2007).

Since DDGS production is concentrated in a few counties while demand is spread across the state, a linear programming transportation model is used to allocate DDGS from ethanol plants to counties. The objective of the model is to minimize total distance traveled.

Great circle distances are calculated for all 131 county pairs (Ballou, 2005). Using latitude and longitude (Lat, Long) coordinates for an origin county $\mathrm{i}$ and destination county $\mathrm{j}$ pair, distance $d_{i j}$ between the counties is calculated as:

2-2 $Y=\operatorname{SIN}\left(\frac{\text { Lat }_{i}}{180 / \pi}\right) * \operatorname{SIN}\left(\frac{\text { Lat }_{j}}{180 / \pi}\right)+\operatorname{COS}\left(\frac{\text { Lat }_{i}}{180 / \pi}\right) * \operatorname{COS}\left(\frac{\text { Lat }_{j}}{180 / \pi}\right) * \operatorname{COS} \frac{{\text { ABS }\left(\text { Long }_{i}-\text { Long }_{j}\right)}_{180 / \pi}}{180}$ 
$2-3 \quad d_{i j}=3959 * A \operatorname{ATN} \sqrt{\frac{1-Y^{2}}{Y}}$

Since $d_{i j}$ provides an estimate of mileage "as the crow flies" it is multiplied by a circuitry factor

of 1.21 to adjust for true one-way distance.

The linear programming transportation model is specified as:

Objective function: Minimize $\sum_{\mathrm{i}} \sum_{\mathrm{j}} \mathrm{d}_{\mathrm{ij}} \mathrm{x}_{\mathrm{cij}}$

subject to:

2-4 Supply limit of $c$ at plant $i: \sum_{j} x_{c i j} \leq a_{j}$ for all $i$

Demand for $c$ incounty $j: \sum_{i j} x_{c i j} \geq b_{j}$ for all $j$

where: $\mathrm{c}$ is the commodity shipped (corn, beans, DDGS, or ethanol)

$i$ is an index for county of origin (ethanol plants producing DDGS)

$\mathrm{j}$ is an index for destination county or demand point to feed livestock

$\mathrm{d}_{\mathrm{ij}}$ is the distance from plant $\mathrm{i}$ to market $\mathrm{j}$

$x_{c i j}$ is the tons of commodity $c$ (DDGS) shipped from plant $i$ to market $j$, all $x_{c i j} \geq 0$

$a_{i}$ is the available supply of DDGS at ethanol plant $i$

$b_{j}$ is the DDGS demand at market $j$

The output of this model provides tons of DDGS allocated from an ethanol plant to fulfill feed demand by county. In 2006, not all demand for DDGS is met on Indiana farms, while in 2008 and 2010 the available supply is much greater than instate demand. Outbound DDGS is allocated to livestock in Indiana via truck using distances from equation 2-3. Daily truck loads of DDGS are estimated as:

2-5 Daily truck loads $\mathrm{cij}_{\mathrm{ij}}=\frac{\text { Tons DDGS allocated from i to } \mathrm{j}}{\text { Days of operation / Truck capacity }}$

Daily truck miles of DDGS are then calculated as: 
2-6 Daily truck miles $_{\mathrm{cij}}=$ Daily Truck Loads cij $_{\mathrm{ij}} * \mathrm{~d}_{\mathrm{ij}}$

Any DDGS remaining after all demand by Indiana livestock is fulfilled is assumed to be transported out of state by rail. Daily rail shipments are calculated as:

2-7 Daily Rail Carloads cij $=\frac{\text { Excess Production }_{\mathrm{cj}}}{\text { Rail Carload Capacity/Days of Operation } \text { O }_{\mathrm{cj}}}$

\subsection{Step 3 - Livestock Feed Demand for Corn}

Corn feeding rates by species depend on whether the animal also consumes DDGS as part of its ration. Assumed feeding rates for corn alone were taken from Quear (2008) and are assumed to be constant over time (Table 2.5). In 2008 and 2010, the supply of DDGS in Indiana meets demand, while there is a shortage in 2006. DDGS fed to animals displaces corn in diets at a rate of .731 pounds of DDGS per pound of corn for dairy cattle, 1.196 for all other cattle, and 0.0890 for swine and poultry, respectively a rate of 1.196 pounds (Arora, Wu, and Wang, 2008).

The county level feed demand for corn is determined by:

2-8 CornFed C $_{\mathrm{i}, \mathrm{s}, \mathrm{t}}=\sum_{\mathrm{s}}\left[\right.$ SmallFarmHerd $_{\mathrm{i}, \mathrm{s}, \mathrm{t}} * \mathrm{Feed} \mathrm{rate}_{\mathrm{i}, \mathrm{s, \textrm {t }}}+$ LargeFarmHerd $\left._{\mathrm{i}, \mathrm{s}, \mathrm{t}} * \mathrm{Feed} \mathrm{rate}_{\mathrm{i}, \mathrm{s, \textrm {t }}}\right]$

where: $i$ is the county of production, $\mathrm{s}$ is the species of animal, and $\mathrm{t}$ is the time period, $\mathrm{t}=2006,2008,2010$.

Livestock and corn production are found in every county in the study area. Livestock are assumed to consume corn raised in the same county. Once livestock feed demand is known for all counties, corn is allocated to fulfill livestock corn demand using a LP transportation model (equation 2-4). Livestock corn demand is fulfilled from production within the county. Daily truckloads are then calculated using equation 2-5. 


\subsection{Step 4 - Estimate Livestock Transportation Requirements}

Miles traveled by each truck is calculated based on the density of grain within the county, or:

2-9 Crop Density $_{\mathrm{gi}}=\frac{\text { Crop Acres }_{\mathrm{gi}}}{\text { Total Acres }_{\mathrm{i}}} *$ Yield $_{\mathrm{gi}} * 640$ acres, where g is corn $/$ beans for county $\mathrm{i}$ Crop acres are defined as total harvested acres and total acres are defined as total land area in county i. Yield is in terms of bushels per acre for corn and beans per county. By multiplying by 640 (the number of acres per square mile), crop density is calculated per square mile basis. Equation 2-9 is solved separately for corn and soybeans for each county and time period.

Distance traveled by each truck is based on radii extending from a demand point j. Corn flows to meet livestock demand are assumed to occur 365 days per year via 500 bushel capacity trucks. Given the demand in a particular county for corn to feed livestock, the total trucks required to meet that demand is determined by equation 2-5 by substituting corn for DDGS. The one-way distance to haul corn to feed livestock is then calculated for each truck as:

2-10 $\mathrm{d}_{\mathrm{ij}}=\sqrt{\frac{\text { Truck }_{\mathrm{n}} * \text { Truck Capacity }_{\mathrm{u}}}{\pi * \text { Crop Density }_{\mathrm{gi}} / \text { Days of Operation }_{\mathrm{u}}}} * 1.21$

where $g$ is the type of grain (corn or soybeans) and $u$ is the grain utilization (feed, food, ethanol, crushing, or grain elevator). This equation is solved iteratively for each truck required to meet demand such that a summation of the distances traveled by each truck provides total miles driven by all trucks, from 1 to $n$. 


\subsection{Step 5 - Corn for Food Processing and Ethanol}

The second category of corn utilization is food processing which includes dry grind and wet grind corn mills. The location and annual corn demanded for seven food processing plants in Indiana is included in the model (Table 2.6). The capacity and location of each plant was obtained from the Milling and Baking News (2008). The 241 million bushels of corn used in Indiana for food processing is 18.3 percent of the U.S. total. Thus, food processing is a key user of corn for Indiana.

Table 2.6. Location and Annual Utilization of Corn by Food Processing Plants in Indiana, 2009

\begin{tabular}{llc}
\hline City $^{1}$ & \multicolumn{1}{c}{ County } & Bushels of Corn Processed per Year \\
\hline Lafayette & Tippecanoe & $92,125,000$ \\
Hammond & Lake & $67,000,000$ \\
Indianapolis & Marion & $33,835,000$ \\
Daviess & Washington & $32,160,000$ \\
Evansville & Vanderburgh & $8,375,000$ \\
Marion & Grant & $4,020,000$ \\
Rochester & Fulton & $4,020,000$ \\
Total & & $241,535,000$ \\
\hline
\end{tabular}

${ }^{1}$ Lafayette, Indianapolis, and Evansville have more than one corn plant. Corn required is total for all plants in the county.

Source: Milling and Baking News, 2008

Corn utilization by ethanol is a third source of corn consumption. Location and capacities of each plant for the three time periods are needed. For 2006, only the plant at South Bend was in operation. The 2008 data are for the nine plants in operation at the end of 2008 (Table 1.8). The 2010 plants include the two idle plants as well as the two plants under construction. 
Food processing plants in Indiana in production in 2006 are assumed to produce at the same rate through 2010. It is also assumed that all plants run at full capacity for 350 days per year. Furthermore, it is assumed that corn is transported to these plants in semi-trailers with a capacity of 920 bushels. Ethanol plants are assumed to operate at full capacity for 354 days per year and also transport corn in 920 bushel semi-trailers (Denicoff, 2007).

Once livestock demand for corn is fulfilled, corn is then allocated to food processing and ethanol plants. Because of the volume of corn demanded by both food processing and ethanol plants is large relative to local production, the draw area for each plant will likely extend into adjacent counties. A linear programming transportation model like equation 2-4 is used to allocate corn by minimizing total distance traveled when allocating corn for all food processing and ethanol plants. The output of this model provides bushels of corn allocated from a production county I to a destination county $\mathrm{j}$ with an ethanol or food processing plant.

The same process to calculate truckloads of corn to meet livestock demand is used for to meet food processing and ethanol utilization of corn. Equations 2-5, 2-9, and 2-10 are used to determine daily inbound trucks and miles traveled by each truck focusing on county level corn production data and food processing and ethanol utilization of corn. A sum of distances for all trucks provides total daily miles traveled. This provides total inbound truck loads and miles traveled for counties with food processing and ethanol plants.

For counties without a food processing or ethanol plants, corn is allocated to destination counties on the basis of the linear programming transportation model. Equations 2-5 and 2-6 are used to determine truck miles. 
Corn remaining after allocation to livestock, food processing, and ethanol plants is transported to local county elevators. Equations 2-5, 2-9, and 2-10 are used to determine daily truckloads required and miles traveled by each truck focusing on corn production (i) and elevator use of corn $(u)$. By summing miles traveled by each truck, total daily truck miles are known.

\subsection{Step 6 -Soybeans for Crushing and Biodiesel}

Soybean demand at the county level is also required which principally is soybean crushing facilities. The location and annual soybean demanded for six soybean crushing facilities are included in the model for all three time periods (Table 2.7). In addition, soybeans are demanded by the biodiesel plants found in the state (Table 1.9). Thus, processing demand for soybeans is 184.9 million bushels in 2006 and 257.4 million bushels in 2008 and 2010. Crushing and biodiesel plants and assumed to operate at full capacity for 350 days per year and be supplied with soybeans via 920 semi-trailers.

Soybeans are then allocated to soybean crushing facilities. Like food processing and corn ethanol plants, the large quantity of soybeans demanded by soybean crushing facilities means that the draw area of each facility will extend into adjacent counties. Thus, the same type of linear programming transportation model is used to allocate soybeans to crushing facilities (equation 24 ). The output of this model provides the allocation of soybeans from production counties to counties with crushing facilities.

Equations 2-5, 2-9, and 2-10 are used to estimate daily inbound truck loads of beans required for each crushing facility and miles traveled by each truck. All equations are used 
Table 2.7. Location and Capacity of Soybean Crushing Plants

\begin{tabular}{llr}
\hline City & \multicolumn{1}{c}{ County } & Bushels of Soybeans per Year \\
\hline Morristown & Shelby & $57,750,000$ \\
Decatur & Adams & $41,580,000$ \\
Frankfort & Clinton & $27,286,875$ \\
Mt. Vernon & Posey & $22,435,875$ \\
Lafayette & Tippecanoe & $19,404,000$ \\
Seymour & Jackson & $9,702,000$ \\
TOTAL & & $178,158,750$
\end{tabular}

Source: Milling and Baking News, 2008

focusing on soybean production data (i) and crushing facility utilization of soybeans (u). A sum

of distances traveled by each truck provides total daily miles traveled for inbound shipments of beans to each crushing facility. Soybeans remaining after demand for all crushing facilities are met are transported to county elevators.

\subsection{Step 7 - Transportation Requirements for Ethanol to Blenders}

Ethanol demand is also needed for the model. The primary demand point for ethanol is gasoline blending terminals where ethanol is blended with gasoline. The location and capacities of blending terminals are obtained from Reynolds (2002).

Ethanol markets west of Indiana are assumed to be satisfied with ethanol from lowa and Illinois. In addition, it is assumed that demands in Kentucky, Michigan, and Ohio are open to ethanol from Indiana by truck. Thus, it is assumed that 760 MGY of ethanol demand can be served from Indiana ethanol plants as a truck market (Table 2.8). After truck markets are served, any remaining ethanol is railed from the region. It is assumed that ethanol transported 
within the truck market is done so via trucks with 8,000 gallon capacities, while ethanol railed out of the region is done so via rail cars with a capacity of 29,400 gallons (Denicoff, 2007).

Table 2.8. Assumed Location and Annual Demands for Ethanol Truck Markets

\begin{tabular}{lc}
\hline Location & Capacity (MGY) \\
\hline Evansville, IN & 40 \\
Huntington, IN & 20 \\
Indianapolis, IN & 155 \\
South Bend, IN & 75 \\
Brookston, IN & 10 \\
Muncie, IN & 20 \\
Lexington, KY & 30 \\
Louisville, KY & 200 \\
Detroit, MI & 160 \\
Marshall, MI & 15 \\
Jackson, MI & 35 \\
TOTAL & 760 \\
\hline
\end{tabular}

Source: (Reynolds 2002)

Outbound ethanol is allocated to truck markets which include gasoline blending terminals in Indiana, Michigan, and Kentucky. Distances between each ethanol plant and each truck market location were obtained from Google Maps. With distances known, a linear programming transportation model like equation 2-4 was used to allocate ethanol between ethanol plants and truck markets. Output from this model provides gallons of ethanol allocated between ethanol plants and blending terminals. Daily truck loads of ethanol are then calculated by the same types of relationships as used for corn, beans, and DDGS. 


\subsection{Step 8 - Grain Shipped from Grain Elevators}

After corn and soybean demands are fulfilled in each county, all remaining grain is transported to local county elevators where it is stored before being shipped out of Indiana. According to Census Data, 81.8 percent of the grain shipped from the state of Indiana moves by rail, with truck involved in the remainder of the movements (which may include a truck/barge haul) (Bureau of Transportation Statistics, 2004). Given the seasonal nature of the elevator industry, elevators operate 250 days per year and grain is received by a combination of 920 bushel semitrailers and 500 bushel farm trucks.

A partial list of 68 county elevators from 42 counties was found in the Milling and Baking News (2008). For each county, the grain elevators are assigned as being either truck, rail, or split on the basis of elevator operating characteristics. For counties with unit train elevators, $98 \%$ of the grain was assumed to be shipped by rail, while if the county had a rail/truck split $92 \%$ was shipped by rail. Counties with truck houses were largely concentrated near the Ohio River.

If an elevator within a particular county has a rail load out capacity of 35,000 bushels per hour or more, the county is classified as being a unit train rail shipper. The 19 counties with "rail" elevators in Indiana are assumed to ship 95\% of the grain by rail (Table 2.9). If no elevator was discovered in a county with rail shipping capability, the county was classified as truck. The 30 truck counties are concentrated near the Ohio River. The remaining 43 counties were classified as split, meaning they ship by some combination of rail and truck. The Excel function Goal Seek was used so that the percent of grain shipped by rail was consistent with the Census tons of 81.8 percent. The "split" counties shipped $83.1 \%$ by rail and the remainder by truck. 
Table 2.9. Distribution of Outbound Shipments by Mode and Bushels Shipped, 2002

\begin{tabular}{lrrr} 
Mode & $\begin{array}{c}\text { Number of Counties } \\
\text { with Mode }\end{array}$ & Total Bushels shipped by Rail & $\begin{array}{c}\text { Total Bushels Shipped by } \\
\text { Truck }\end{array}$ \\
\hline Rail & 19 & $94,178,187$ & $4,956,747$ \\
Split & 43 & $251,408,375$ & $50,969,862$ \\
Truck & $\underline{30}$ & 0 & $20,964,289$ \\
Total & 92 & $345,586,562$ & $76,890,898$ \\
\hline
\end{tabular}

SOURCE: Bureau of Transportation Statistics, 2004.

\subsection{Summary of Model}

The eight steps estimate daily truck loads and miles for corn, soybeans, ethanol, and DDGS as well as daily rail carloads of ethanol, DDGS, and grain leaving Indiana at the county level. Results of the model are discussed in the next chapter. 


\section{Chapter 3 - Empirical Results}

To determine changes in transportation requirements among the three time periods, differences in truck and rail loads, miles driven (VMTs), and average length of haul are compared. Differences between time periods signal expected changes in transportation requirements caused by the expansion of biofuels in Indiana.

The model described in Chapter 2 was built in Excel, using output from four linear programming models providing allocations of corn, soybeans, DDGS, and ethanol. Three models were estimated for all 92 counties in Indiana, plus 39 border counties in adjacent states. The three models are a baseline (2006) which can be compared with a short term adjustment (2008) and a long term adjustment (2010). In this chapter, state level results are reported for Indiana.

This chapter will examine the statewide results in detail. A wealth of information is available, including: 1) changes in grain production and utilization, 2) inbound truckloads of corn and soybeans to meet demands for livestock, food processing, ethanol, oilseed crushing, and grain elevators, and 3) outbound shipments of corn, soybeans, DDGS, and ethanol, by truck and rail. Results are first reported at the state level for average one-way $L O H$, number of loads per day, and daily and annual VMT for the various inbound and outbound movements. Next annual totals are reported, with a focus on the relative contributions of the different inbound and outbound movements. Finally, annual totals are compared for four types of counties, those counties with new and incumbent biofuels plants, the counties bordering those with ethanol plants, and all other counties. 


\subsection{Statewide Grain Production}

Since 2006, higher corn and bean prices, in part due to the growth in biofuels, have led to increased grain production in Indiana. From 2006 to 2008, total corn bushels in Indiana rose by 7.1 percent, and are projected to grow by an additional 4.9 percent from 2008 to 2010 (Table 3.1). Soybean production fell by 10.3 percent from 2006 and 2008, but then rebounds from 2008 to 2010 by 10.4 percent. Total bushels of corn and beans grow from 1.14 to 1.18 billion to 1.25 billion bushels in 2006, 2008, and 2010, respectively. This represents a total growth of 2.9 and 6.1 percent between the time periods in available bushels to be moved. Thus, part of the growth in grain transportation in Indiana is simply that there is more production. However, in part this is offset because corn and soybean density also increase over time, meaning that grain production is more concentrated.

Table 3.1. Indiana Grain Production, Yield, and Density, by Year

\begin{tabular}{lrrrrr}
\hline Grain Production & \multicolumn{3}{c}{ Model } & \multicolumn{2}{c}{ \% change from: } \\
\cline { 2 - 6 } & \multicolumn{1}{c}{2006} & \multicolumn{1}{c}{2008} & 2010 & 06 to 08 & 08 to 10 \\
\hline Corn Production ( M bu) & 866.9 & 928.1 & 974.0 & $7.1 \%$ & $4.9 \%$ \\
Soybean Production (M bu) & 277.4 & 249.0 & -275.0 & $-10.2 \%$ & $\underline{10.4 \%}$ \\
Total bushels (M bu) & $1,144.3$ & $1,177.1$ & $1,248.9$ & $2.9 \%$ & $6.1 \%$ \\
\hline Corn Yield (bu/acre) & 151.0 & 149.7 & 157.2 & $-0.8 \%$ & $5.0 \%$ \\
Soybean Yield (bu/acre) & 49.3 & 45.2 & 48.2 & $-8.3 \%$ & $6.8 \%$ \\
Corn Density (bu/section) & 23,531 & 25,163 & 26,405 & $6.9 \%$ & $4.9 \%$ \\
Soybean Density (bu/section) & 7,613 & 6,833 & 7,546 & $-10.3 \%$ & $10.4 \%$ \\
\hline
\end{tabular}

Livestock consumption of corn fell from 2006 to 2008 by 3.0 percent, and is forecast to fall an additional 16.3 percent from 2008 to 2010 (Table 3.2). The sole reason underlying the 
Table 3.2. Truckloads, VMT, and Average LOH for Livestock Utilization of Corn, by Year

\begin{tabular}{lrrrrr}
\hline Livestock Utilization & \multicolumn{1}{c}{ Model } & \multicolumn{2}{c}{ \% change from: } \\
& \multicolumn{1}{c}{2006} & \multicolumn{1}{c}{2008} & 2010 & \multicolumn{1}{c}{06 to 08 } & 08 to 10 \\
\hline Corn consumed (M bu) & 116.5 & 113.0 & 94.5 & $-3.0 \%$ & $-16.3 \%$ \\
Daily Loads & 686 & 666 & 560 & $-2.9 \%$ & $-15.9 \%$ \\
Daily VMT (miles) & 3,470 & 2,703 & 2,011 & $-22.1 \%$ & $-25.6 \%$ \\
Average LOH (miles/trip) & 5.1 & 4.1 & 3.6 & $-19.8 \%$ & $-11.5 \%$ \\
Annual Loads & 250,390 & 243,090 & 204,400 & $-2.9 \%$ & $-15.9 \%$ \\
Annual VMT (000 miles) & $1,266.6$ & 986.6 & 734.2 & $-22.1 \%$ & $-25.6 \%$ \\
\hline
\end{tabular}

decline is the replacement of corn by DDGS in livestock feed rations (see Table 2.5). The assumed livestock consumption of DDGS is saturated in Indiana in 2008. Consumption increases from 2008 to 2010 because inclusion rates of DDGS in animal rations are forecast to increase as farmers become familiar with the using DDGS.

Reliable data about DDGS consumption are not available. Most likely the assumed DDGS feeding rates likely overstate the adoption of DDGS as a substitute for corn and should be viewed as a measure of DDGS market potential. To that extent, the model understates outbound shipments of DDGS from Indiana via rail and overstates available corn, which likely was consumed by livestock. VMTs for Indiana corn fed to livestock decreased by 22.1 percent between 2006 and 2008, and are forecast to fall an additional 25.6 percent from 2008 to 2010 . VMTs fell more than corn bushels consumed by livestock because corn density increased over time (Table 3.1). The average one-way LOH fell from 5.1 to 3.6 miles per trip. Thus, livestock consumption represents very short one-way hauls.

The number of food processing plants were unchanged over the three time periods and therefore, corn consumption and daily truckloads for food processing also were stable (Table 
3.3). However, changes in corn production and density as well as changes in other types of corn utilization cause daily VMT traveled to change slightly. From 2006 to 2008, VMTs decreased by a few thousand miles, but will drop by 2.4 percent from 2008 to 2010 . Although VMTs change, one way average LOH remains virtually constant, near 27 miles per trip, because the change in miles is very small. Compared to livestock, average $\mathrm{LOH}$ is much further due to the large volume of corn consumed at one location by each food processing plant.

Table 3.3. Truckloads, VMT, and Average LOH for Food Processing Utilization of Corn, by Year

\begin{tabular}{lrrrrr}
\hline Food Processing & \multicolumn{1}{c}{ Model } & \multicolumn{3}{c}{ \% change from: } \\
Utilization & \multicolumn{1}{c}{2006} & \multicolumn{1}{c}{2008} & 2010 & 06 to 08 & 08 to 10 \\
\hline Corn consumed (M bu) & 241.5 & 241.5 & 241.5 & $0.0 \%$ & $0.0 \%$ \\
Daily Loads & 768 & 767 & 766 & $-0.1 \%$ & $-0.1 \%$ \\
Daily VMT (miles) & 21,287 & 21,280 & 20,853 & $0.0 \%$ & $-2.0 \%$ \\
Average LOH (miles/trip) & 27.7 & 27.7 & 27.2 & $0.1 \%$ & $-1.9 \%$ \\
Annual Loads & 268,800 & 268,450 & 268,100 & $-0.1 \%$ & $-0.1 \%$ \\
Annual VMT (000 miles) & $7,450.3$ & $7,447.8$ & $7,298.5$ & $0.0 \%$ & $-2.0 \%$ \\
\hline
\end{tabular}

The number of ethanol plants in Indiana for 2006, 2008, and 2010 are 1, 9, and 13, respectively (Table 1.8). As large users of corn, each additional ethanol plant causes in-state corn utilization to grow. Statewide, daily and annual truckloads to ethanol plants increased by 590.0 percent with annual loads increasing from 39,648 to 271,164 from 2006 to 2008 and then by an additional 51.4 percent to 410,640 from 2008 to 2010 (Table 3.4). VMTs increase by 443.1 percent, from 696,100 to 3.78 million miles, and 59.59 percent to 6.03 million miles over the same periods. Although truckloads and VMTs sharply increased, one-way average LOH for ethanol remained fairly constant, between 14 and 17 miles. The decrease in average trip miles 
Table 3.4. Truckloads, VMT, and Average Trip Miles for Ethanol Utilization of Corn, by Year

\begin{tabular}{lrrrrr}
\hline Ethanol Utilization & \multicolumn{1}{c}{ Model } & \multicolumn{2}{c}{ \% change from: } \\
\cline { 2 - 5 } & \multicolumn{1}{c}{2006} & \multicolumn{1}{c}{2008} & 2010 & 06 to 08 & 08 to 10 \\
\hline Corn consumed (M bu) & 35.6 & 245.6 & 373.0 & $590.0 \%$ & $51.9 \%$ \\
Daily Loads & 112 & 766 & 1,160 & $583.9 \%$ & $51.4 \%$ \\
Daily VMT (miles) & 1,966 & 10,680 & 17,039 & $443.1 \%$ & $59.5 \%$ \\
Average LOH (miles/trip) & 17.6 & 13.9 & 14.7 & $-20.6 \%$ & $5.4 \%$ \\
Annual Loads & 39,648 & 271,164 & 410,640 & $583.9 \%$ & $51.4 \%$ \\
Annual VMT (000 miles) & 696.1 & $3,780.6$ & $6,031.7$ & $443.1 \%$ & $59.5 \%$ \\
\hline
\end{tabular}

between 2006 and 2008 can be explained in that ethanol plants constructed were located in the northern half of Indiana where corn density is much higher. Ethanol average LOH is approximately half the distance of food processing. This is because food processing plants are dispersed throughout the entire state (including southern Indiana where corn density is lower) whereas ethanol plants are primarily located in the northern half of Indiana (Figure 3-1).

Because corn is only transported to country elevators after livestock, food processing, and ethanol demands are first met, the addition of ethanol plants in 2008 and 2010 directly affects the amount of corn available to be allocated to elevators. Bushels of corn, daily loads, and annual loads decrease by roughly 25 percent from 2006 to 2008 with annual loads decreasing from 860,500 to 648,000 and then by an additional 3.45 percent to 625,750 loads from 2008 to 2010 (Table 3.5). VMTs decreased from 7.3 to 5.5 to 5.3 million miles from 2006 to 2008 to 2010. Average LOH was constant at 8.4 miles per trip. As anticipated, trips to haul corn to elevator are typically a short distance. 
Figure 3-1. Classification of Indiana Counties

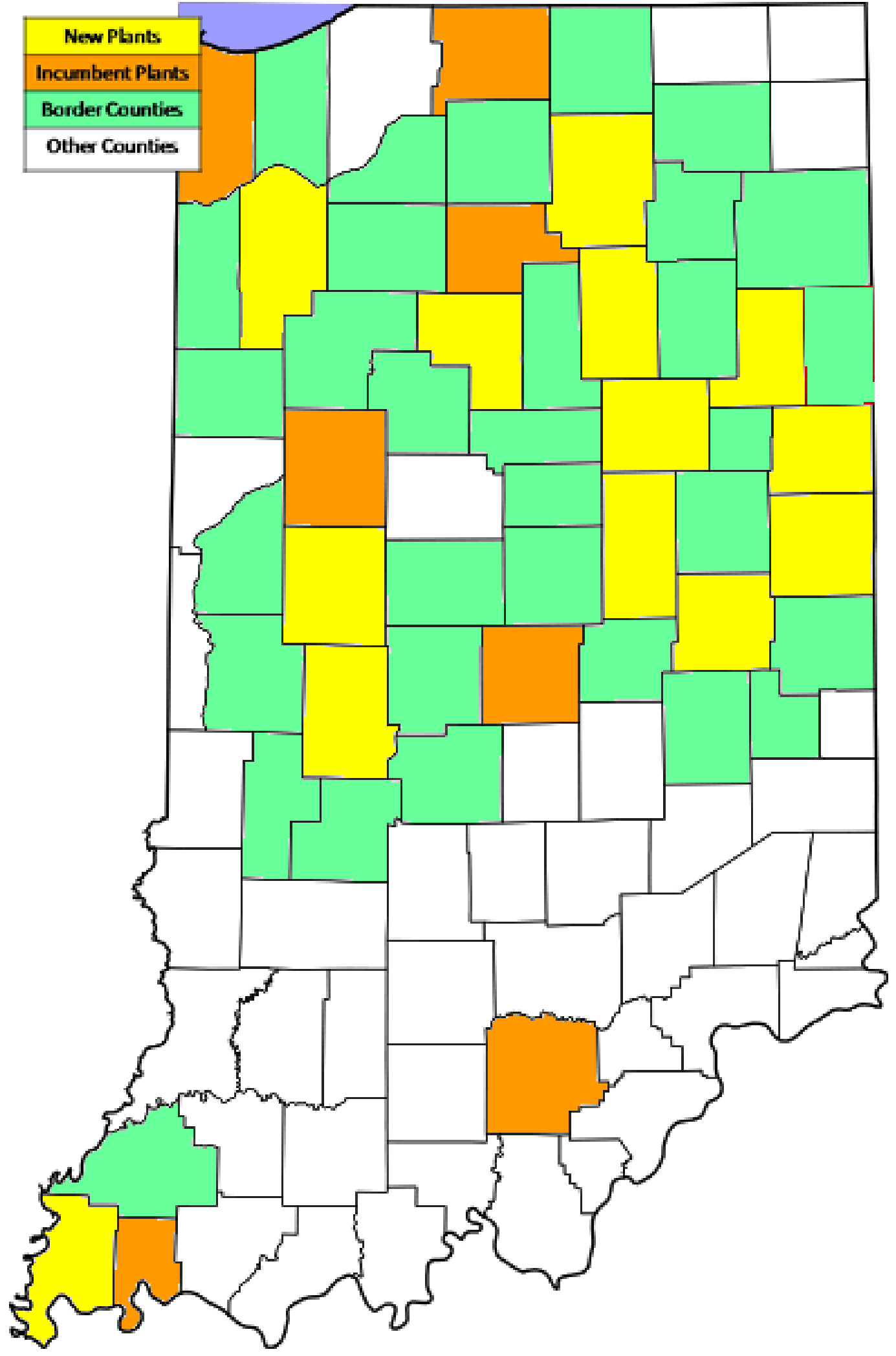


Table 3.5. Truckloads, VMT, and Average LOH for Elevator Utilization of Corn, by Year

\begin{tabular}{lrrrrr}
\hline Elevator Utilization & \multicolumn{1}{c}{ Model } & \multicolumn{2}{c}{ \% change from: } \\
\cline { 2 - 6 } & \multicolumn{1}{c}{2006} & \multicolumn{1}{c}{2008} & 2010 & \multicolumn{1}{c}{06 to 08 } & 08 to 10 \\
\hline Corn consumed (M bu) & 511.5 & 384.6 & 371.6 & $-24.8 \%$ & $-3.4 \%$ \\
Daily Loads & 3,442 & 2,592 & 2,503 & $-24.7 \%$ & $-3.4 \%$ \\
Daily VMT (miles) & 29,038 & 22,016 & 21,039 & $-24.2 \%$ & $-4.4 \%$ \\
Average LOH (miles/trip) & 8.4 & 8.5 & 8.4 & $0.7 \%$ & $-1.0 \%$ \\
Annual Loads & 860,500 & 648,000 & 625,750 & $-24.7 \%$ & $-3.4 \%$ \\
Annual VMT (000 miles) & $7,259.4$ & $5,503.9$ & $5,259.7$ & $-24.2 \%$ & $-4.4 \%$ \\
\hline
\end{tabular}

The changes in soybean crushing utilization of soybeans occur in the 2008 model with the addition of biodiesel plants at Claypool in Kosciusko County and Middletown in Henry County. Changes between 2006 and 2008 were substantial. Soybean bushels consumed and number of loads increased by 36 percent with annual loads increasing from 209,650 to 285,950 (Table 3.6). VMTs increased by 62.5 percent, rising from 5.1 to 8.3 million miles, while average LOH increased by 19.1 percent from 24.2 to 28.8 miles. With no additional crushing, changes for soybeans from 2008 to 2010 were minor for VMTs as well as average trips, representing changes in production and density.

Table 3.6. Truckloads, VMT, and Average LOH for Crushers Utilization of Soybeans, by Year

\begin{tabular}{lrrrrr}
\hline Crushing Facility Utilization & \multicolumn{1}{c}{ Model } & \multicolumn{1}{c}{ \% change from: } \\
\cline { 2 - 5 } & \multicolumn{1}{c}{2006} & 2008 & 2010 & 06 to 08 & 08 to 10 \\
\hline Beans consumed (M bu) & 184.9 & 250.6 & 250.6 & $35.6 \%$ & $0.0 \%$ \\
Daily Loads & 599 & 817 & 816 & $36.4 \%$ & $-0.1 \%$ \\
Daily VMT (miles) & 14,479 & 23,529 & 22,382 & $62.5 \%$ & $-4.9 \%$ \\
Average LOH (miles/trip) & 24.2 & 28.8 & 27.4 & $19.1 \%$ & $-4.8 \%$ \\
Annual Loads & 209,650 & 285,950 & 285,600 & $36.4 \%$ & $-0.1 \%$ \\
Annual VMT (000 miles) & $5,067.7$ & $8,235.0$ & $7,833.6$ & $62.5 \%$ & $-4.9 \%$ \\
\hline
\end{tabular}


Because of the addition of a crushing capacity and a decrease in total soybean production from 2006 to 2008, soybeans allocated to country elevators, number of loads, and VMTs decreased by approximately 64 percent with annual loads decreasing from 216,750 to 79,500 and VMTs from 1.9 million to 680,400 miles (Table 3.7). However, this had no effect on average LOH, remaining around 8.6 miles. From 2008 to 2010, crushing capacity remained constant while soybean production increased. This increased the soybeans transported to elevators and loads by around 50 percent during this time. VMTs increased by 50 percent and average $\mathrm{LOH}$ was unchanged due to the increase in soybean production

Table 3.7. Truckloads, VMT, and Average LOH for Elevator Utilization of Soybeans, by Year

\begin{tabular}{lrrrrr}
\hline Elevator Utilization & \multicolumn{1}{c}{ Model } & \multicolumn{2}{c}{ \% change from: } \\
\cline { 2 - 6 } & \multicolumn{1}{c}{2006} & \multicolumn{1}{c}{2008} & 2010 & \multicolumn{1}{c}{06 to 08 } & 08 to 10 \\
\hline Beans consumed (M bu) & 125.1 & 43.9 & 66.2 & $-64.9 \%$ & $50.6 \%$ \\
Daily Loads & 867 & 318 & 480 & $-63.3 \%$ & $50.9 \%$ \\
Daily VMT (miles) & 7,714 & 2,722 & 4,090 & $-64.7 \%$ & $50.3 \%$ \\
Average LOH (miles/trip) & 8.9 & 8.6 & 8.5 & $-3.8 \%$ & $-0.4 \%$ \\
Annual Loads & 216,750 & 79,500 & 120,000 & $-63.3 \%$ & $50.9 \%$ \\
Annual VMT (000 miles) & $1,928.4$ & 680.4 & $1,022.5$ & $-64.7 \%$ & $50.3 \%$ \\
\hline
\end{tabular}

\subsection{Statewide Outbound Ethanol, DDGS, and Grain Flows}

With the addition of 8 ethanol plants from 2006 to 2008, ethanol production and outbound deliveries of ethanol to blenders increased by 590 percent from 36 to 248 truckloads per day (Table 3.8). The truck market for ethanol produced in Indiana is 760 million gallons, with most of the ethanol demand in Indiana or a short distance into bordering states. From 2006 to 2008, VMTs increased 2,323 percent with annual miles increasing from 445,400 to 10,793,900. 
Table 3.8. Truck and Rail Loads, VMT, and LOH for Outbound Ethanol, by Year

\begin{tabular}{lrrrrr}
\hline Outbound Ethanol & \multicolumn{1}{c}{ Model } & \multicolumn{2}{c}{ \% change from: } \\
\cline { 2 - 6 } & \multicolumn{1}{c}{2006} & \multicolumn{1}{c}{2008} & 2010 & \multicolumn{1}{c}{06 to 08 } & \multicolumn{1}{c}{08 to 10} \\
\hline Ethanol Production (BGY) & 100.0 & 690.0 & $1,048.0$ & $590.0 \%$ & $51.9 \%$ \\
Daily Truckloads & 36 & 248 & 273 & $588.9 \%$ & $10.1 \%$ \\
Daily VMT (miles) & 1,258 & 30,491 & 28,386 & $2323.3 \%$ & $-6.9 \%$ \\
Average LOH (miles/trip) & 35.0 & 122.9 & 104.0 & $251.8 \%$ & $-15.4 \%$ \\
Daily Rail Tankloads & 0.0 & 0.0 & 30.0 & $\mathrm{NA}$ & $\mathrm{NA}$ \\
Annual Truckloads & 12,744 & 87,792 & 96,642 & $588.9 \%$ & $10.1 \%$ \\
Annual VMT (000 miles) & 445.4 & $10,793.9$ & $10,048.7$ & $2323 \%$ & $-6.9 \%$ \\
Annual Rail Tankloads & 0.0 & 0.0 & $10,620.0$ & $\mathrm{NA}$ & $\mathrm{NA}$ \\
\hline
\end{tabular}

Initially, as more ethanol plants are constructed, they serve truck markets. In turn, this causes the average LOH to increase by 251 percent from 35.6 to 122.9 miles per trip. In both 2006 and 2008, total ethanol production is less than the total truck market demand, and thus no ethanol is transported via rail. From 2008 to 2010, four additional ethanol plants come online, which increases capacity by 51.9 percent. This additional capacity fulfills the truck market demand of 760 million gallons, meaning ethanol is also transported by rail in 2010. From 2008 to 2010, truckloads increase an additional 10.1 percent with annual loads increasing from 87,792 to 96,642, while VMTs fall by 7 percent as annual VMTs drop to $10,048,700$ miles. Miles traveled fall because plants open closer to some of the blending markets. Annual rail tanker carloads increase from 0 in 2008 to 10,620 in 2010.

An increase in ethanol production also means an increase in DDGS production. As mentioned earlier, the decrease in corn consumption by livestock is supplemented by the addition of DDGS into livestock diets which is the truck market demand. From 2006 to 2008, the number of truckloads per day rose from 22 to 34 (Table 3.9). Given the proximity of the 
Table 3.9. Truck and Rail Loads, VMT, and Average LOH for Outbound DDGS, by Year

\begin{tabular}{|c|c|c|c|c|c|}
\hline \multirow[t]{2}{*}{ Outbound DDGS } & \multicolumn{3}{|c|}{ Model } & \multicolumn{2}{|c|}{ \% change from: } \\
\hline & 2006 & 2008 & 2010 & 06 to 08 & 08 to 10 \\
\hline DDGS Production ( $\mathrm{M}$ tons) & 0.30 & 2.04 & 3.09 & $590.0 \%$ & $51.9 \%$ \\
\hline Daily Truckloads & 22 & 34 & 99 & $54.5 \%$ & $191.2 \%$ \\
\hline Daily VMT (miles) & 1,802 & 1,519 & 3,303 & $-15.7 \%$ & $117.5 \%$ \\
\hline Average LOH (miles/trip) & 81.9 & 44.7 & 33.4 & $-45.5 \%$ & $-25.3 \%$ \\
\hline Daily Rail Carloads & 3.0 & 55.0 & 72.0 & $1733.3 \%$ & $30.9 \%$ \\
\hline Annual Truckloads & 7,788 & 12,036 & 35,046 & $54.5 \%$ & $191.2 \%$ \\
\hline Annual VMT (000 miles) & 637.8 & 537.7 & $1,169.2$ & $-15.7 \%$ & $117.5 \%$ \\
\hline Annual Rail Carloads & $1,062.0$ & $19,470.0$ & $25,488.0$ & $1733.3 \%$ & $30.9 \%$ \\
\hline
\end{tabular}

one ethanol plant in 2006 (St. Joseph County) to the border with Michigan, some of the output is shipped by rail to out of state markets, although it likely moves by truck. By 2008, DDGS production greatly exceeds the local truck market demand, leading the amount to be shipped by rail to jump by 1,733 percent from 1,062 to 19,470 rail carloads. Truckloads of DDGS increased during this time by 35 percent from 7,788 to 12,036 . During this time, ethanol plants are more dispersed throughout the state causing average LOH for trucks to fall by 45 percent from 81.9 to 44.7 miles. DDGS production increases an additional 51.9 percent from 2008 to 2010, but more DDGS is assumed to be fed within the local truck market as inclusion rates increase. Thus, truckloads rise by 191 percent to 35,046 per year, while rail carloads climb to 25,488 per year. The average LOH for trucks drops to 33.4 miles per trip.

The changes in corn utilization by livestock and ethanol over the three time periods affect outbound shipments of corn from elevators via rail and truck. From 2006 to 2008, total bushels of outbound corn decreased by 25 percent as that corn is now processed in Indiana 
Table 3.10). During this time, daily outbound truckloads fell 13 percent, from 450 to 393, while daily rail carloads decreased by 28 percent from 506 to 364 . VMTs decreased by 38.1 percent and average LOH decreased by 29.1 percent. From 2008 to 2010 corn available for outbound shipment decreases an additional 3.4 percent to 371.6 million bushels. Daily truckloads decrease by 1.8 percent, but VMTs and LOH increase by 29.7 and 32.1 percent, respectively. Rail carloads decrease by 5.8 percent during this time. These changes in outbound corn flows can be explained primarily by the increase in instate consumption of corn from ethanol plants which reduces the amount of corn available for outbound shipment.

Table 3.10. Truckloads, Rail Carloads, VMT, and Average LOH for Outbound Corn, by Year

\begin{tabular}{lrrrrr}
\hline Outbound Corn & \multicolumn{1}{c}{ Model } & \multicolumn{1}{c}{ \% change from: } \\
\cline { 2 - 6 } & \multicolumn{1}{c}{ 2006 } & \multicolumn{1}{c}{2008} & 2010 & 06 to 08 & 08 to 10 \\
\hline Corn in Elevator (M bu) & 511.5 & 384.6 & 371.6 & $-24.8 \%$ & $-3.4 \%$ \\
Daily Truckloads & 450.0 & 393.0 & 386.0 & $-12.7 \%$ & $-1.8 \%$ \\
Daily VMT (miles) & $24,666.9$ & $15,271.4$ & $19,810.6$ & $-38.1 \%$ & $29.7 \%$ \\
Average LOH (miles/trip) & 54.8 & 38.9 & 51.3 & $-29.1 \%$ & $32.1 \%$ \\
Daily Rail Carloads & 506.0 & 364.0 & 343.0 & $-28.1 \%$ & $-5.8 \%$ \\
Annual Truckloads & 112,500 & 98,250 & 96,500 & $-12.7 \%$ & $-1.8 \%$ \\
Annual VMT (000 mi) & $6,166.7$ & $3,817.8$ & $4,952.6$ & $-38.1 \%$ & $29.7 \%$ \\
Annual Rail Carloads & $126,500.0$ & $91,000.0$ & $85,750.0$ & $-28.1 \%$ & $-5.8 \%$ \\
\hline
\end{tabular}

The addition of two biodiesel plants in 2008 was the only major change in soybean utilization. Coupled with a decrease in soybean production in 2008 caused soybeans available for shipment from Indiana to decrease by 65 percent from 2006 to 2008 (Table 3.11). Truckloads, VMTs, and average LOH decrease 50.0, 51.6, and 3.3 percent, respectively, while 
Table 3.11. Truckloads, Rail Carloads, VMT, and Average LOH for Outbound Soybeans, by Year

\begin{tabular}{lrrrrr}
\hline Outbound Soybeans & \multicolumn{1}{c}{ Model } & \multicolumn{2}{c}{ \% change from: } \\
\cline { 2 - 5 } & \multicolumn{1}{c}{ 2006 } & \multicolumn{1}{c}{2008} & 2010 & \multicolumn{1}{c}{06 to 08 } & 08 to 10 \\
\hline Soybeans in Elevator (M bu) & 125.1 & 43.9 & 66.2 & $-64.9 \%$ & $50.6 \%$ \\
Daily Truckloads & 158.0 & 79.0 & 114.0 & $-50.0 \%$ & $44.3 \%$ \\
Daily VMT (miles) & $6,851.7$ & $3,312.9$ & $4,378.6$ & $-51.6 \%$ & $32.2 \%$ \\
Average LOH (miles/trip) & 43.4 & 41.9 & 38.4 & $-3.3 \%$ & $-8.4 \%$ \\
Daily Rail Carloads & 137.0 & 54.0 & 85.0 & $-60.6 \%$ & $57.4 \%$ \\
Annual Truckloads & 39,500 & 19,750 & 28,500 & $-50.0 \%$ & $44.3 \%$ \\
Annual VMT (000 miles) & $1,712.9$ & 828.2 & $1,094.6$ & $-51.6 \%$ & $32.2 \%$ \\
Annual Rail Carloads & 34.3 & 13.5 & 21.3 & $-60.6 \%$ & $57.4 \%$ \\
\hline
\end{tabular}

rail carloads decrease 60.6 percent during this time. From 2008 to 2010, the only change is an increase in soybean production of 10.4 percent (Table 3.1). As a result, truckloads increase by 44.3 percent while VMTs increase by 32.2 percent. Average LOH decreases by an additional 8.4 percent during this time. Rail carloads increase by 27.4 percent.

An additional way to examine the results is to focus on the relative contributions of different inbound and outbound shipments. Corn utilization by livestock, food processors, ethanol plants, and elevators shift as additional ethanol plants begin production. Livestock's share of utilization of corn declines from 12.9 percent of the crop in 2006 to 8.7 percent in 2010 (Table 3.12). This occurs due to the incorporation of DDGS in livestock rations in lieu of corn. Although no food processing plants were constructed between 2006 and 2010, their share of corn utilization falls slightly from 26.7 to 22.4 percent due to increased corn production. Because the major difference between each model year are additions of ethanol plants, 
Table 3.12. Summary of Corn Utilization by Type, by Year

\begin{tabular}{lrrrrrr}
\hline Corn Utilization & \multicolumn{2}{c}{2006} & \multicolumn{2}{c}{2008} & \multicolumn{2}{c}{2010} \\
\cline { 2 - 7 } & $\begin{array}{c}\text { Bushels } \\
\text { (M bu) }\end{array}$ & $\begin{array}{c}\text { Percent of } \\
\text { Total }\end{array}$ & $\begin{array}{c}\text { Bushels } \\
\text { (M bu) }\end{array}$ & $\begin{array}{c}\text { Percent of } \\
\text { Total }\end{array}$ & $\begin{array}{r}\text { Bushels } \\
\text { (M bu) }\end{array}$ & $\begin{array}{c}\text { Percent of } \\
\text { Total }\end{array}$ \\
\hline Livestock & 116.5 & $12.9 \%$ & 113.0 & $11.5 \%$ & 94.5 & $8.7 \%$ \\
Food & 241.5 & $26.7 \%$ & 241.5 & $24.5 \%$ & 241.5 & $22.4 \%$ \\
Ethanol & 35.6 & $3.9 \%$ & 245.6 & $24.9 \%$ & 373.0 & $34.5 \%$ \\
Elevators & $\underline{511.5}$ & $\underline{56.5 \%}$ & $\underline{384.6}$ & $\underline{39.1 \%}$ & $\underline{371.6}$ & $\underline{34.4 \%}$ \\
Total & 905.1 & $100.0 \%$ & $\underline{984.7}$ & $100.0 \%$ & $1,080.6$ & $100.0 \%$ \\
\hline
\end{tabular}

ethanol's share of corn utilization increases from 3.9 percent in 2006 to 24.9 percent in 2008 to 34.5 percent by 2010. Elevator utilization of corn declines from 56.5 percent in 2006 to 32.4 percent in 2010 which can be interpreted as a decline in corn available for shipment from Indiana since corn shipped to elevators is assumed to leave Indiana.

Likewise, soybean share between crushing facilities and country elevators shifts with the addition of two biodiesel plants in the 2008 model. Crushing facility's share of utilization of soybeans increases from 59.6 percent in 2006 to 79.1 percent in 2010 (Table 3.13). Thus, elevator's share of the soybean market declines from 40.4 percent to 20.9 percent during this time.

Table 3.13. Summary of Soybean Utilization by Type, by Year

\begin{tabular}{lrrrrrr}
\hline Soybean Utilization & \multicolumn{2}{c}{2006} & \multicolumn{2}{c}{2008} & \multicolumn{2}{c}{2010} \\
\cline { 2 - 7 } & $\begin{array}{c}\text { Bushels } \\
\text { (M bu) }\end{array}$ & $\begin{array}{r}\text { Percent } \\
\text { of Total }\end{array}$ & $\begin{array}{r}\text { Bushels } \\
\text { (M bu) }\end{array}$ & $\begin{array}{r}\text { Percent } \\
\text { of Total }\end{array}$ & $\begin{array}{r}\text { Bushels } \\
\text { (M bu) }\end{array}$ & $\begin{array}{r}\text { Percent } \\
\text { of Total }\end{array}$ \\
\hline Crushing & 184.9 & $59.6 \%$ & 250.6 & $85.1 \%$ & 250.6 & $79.1 \%$ \\
Elevators & $\underline{125.1}$ & $\underline{40.4 \%}$ & $\underline{43.9}$ & $\underline{14.9 \%}$ & $\underline{66.2}$ & $\underline{20.9 \%}$ \\
Total & 309.9 & $100.0 \%$ & 294.6 & $100.0 \%$ & 316.8 & $100.0 \%$ \\
\hline
\end{tabular}


Annual totals inbound and outbound truckloads and outbound railcars for 2006, 2008, and 2010 are compared in evaluate the overall change between each period (Table 3.14). To further understand changes between each period, annual VMTs are also compared for each year (Table 3.15). Inbound truckloads include grain shipments to livestock, food processing, ethanol, crushers, and grain elevators. Outbound truckloads include corn and soybeans shipped from elevators to destinations outside of Indiana and ethanol and DDGS shipped from ethanol plants to their respective truck markets.

Table 3.14. Annual Truckloads and Rail Carloads by Commodity, by Year

\begin{tabular}{|c|c|c|c|c|}
\hline \multirow[t]{2}{*}{ Movement/Mode/Utilization } & 2006 & 2008 & 2010 & \multirow{2}{*}{$\begin{array}{c}\% \text { change } \\
\text { from } 06 \text { to } 10\end{array}$} \\
\hline & \multicolumn{3}{|c|}{ Truckloads (in thousands) } & \\
\hline Inbound Corn - Livestock & 250.4 & 243.1 & 204.4 & $-18.4 \%$ \\
\hline Inbound Corn - Food Processing & 268.8 & 268.5 & 268.1 & $-0.3 \%$ \\
\hline Inbound Corn - Ethanol & 39.6 & 271.2 & 410.6 & $935.7 \%$ \\
\hline Inbound Corn - Elevator & 860.5 & 648.0 & 625.8 & $-27.3 \%$ \\
\hline Inbound Soybeans - Crushing & 209.7 & 286.0 & 285.6 & $36.2 \%$ \\
\hline Inbound Soybeans - Elevator & $\underline{216.8}$ & 79.5 & 120.0 & $-44.6 \%$ \\
\hline Total Inbound Truck Movements & $1,845.7$ & $1,796.2$ & $1,914.5$ & $3.7 \%$ \\
\hline Outbound Truck - Ethanol & 12.7 & 87.8 & 96.6 & $658.3 \%$ \\
\hline Outbound Truck - DDGS & 7.8 & 12.0 & 35.0 & $350.0 \%$ \\
\hline Outbound Truck - Corn & 112.5 & 98.3 & 96.5 & $-14.2 \%$ \\
\hline Outbound Truck - Beans & $\underline{39.5}$ & $\underline{19.8}$ & $\underline{28.5}$ & $\underline{-27.8 \%}$ \\
\hline Total Outbound Truck & 172.5 & 217.8 & 256.7 & $48.8 \%$ \\
\hline \multirow[t]{2}{*}{ Total Truck Loads } & $\underline{\underline{2,018.27}}$ & $\underline{\underline{2,013.98}}$ & $\underline{\underline{2,171.18}}$ & $7.6 \%$ \\
\hline & \multicolumn{3}{|c|}{ Rail Carloads } & \\
\hline Outbound Rail - Ethanol & 0 & 0 & 10,620 & NA \\
\hline Outbound Rail - DDGS & 1,062 & 19,470 & 25,488 & $2300.0 \%$ \\
\hline Outbound Rail - Corn & 126,500 & 91,000 & 85,750 & $-32.2 \%$ \\
\hline Outbound Rail - Soybean & 34,250 & 13,500 & 21,250 & $-38.0 \%$ \\
\hline Total Outbound Rail Carloads & 161,812 & 123,970 & 143,108 & $-11.6 \%$ \\
\hline
\end{tabular}


Table 3.15. Annual VMT by Commodity, by Year

\begin{tabular}{lrrrr}
\hline Annual VMT & \multicolumn{1}{c}{2006} & \multicolumn{1}{c}{2008} & \multicolumn{1}{c}{2010} & $\begin{array}{r}\text { \% change from } \\
\text { 06 to } 10\end{array}$ \\
\cline { 2 - 4 } & \multicolumn{3}{c}{ O00 VMT in miles } \\
\hline Inbound Corn: Livestock & $1,266.6$ & 986.6 & 734.2 & $-42.0 \%$ \\
Inbound Corn: Food Processing & $7,450.3$ & $7,447.8$ & $7,298.5$ & $-2.0 \%$ \\
Inbound Corn: Ethanol & 696.1 & $3,780.6$ & $6,031.7$ & $766.5 \%$ \\
Inbound Corn: Elevator & $7,259.4$ & $5,503.9$ & $5,259.7$ & $-27.5 \%$ \\
Inbound Soybeans: Crushing & $5,067.7$ & $8,235.0$ & $7,833.6$ & $54.6 \%$ \\
Inbound Soybeans: Elevator & $\underline{1,928.4}$ & $\underline{680.4}$ & $\underline{1,022.5}$ & $\underline{-47.0 \%}$ \\
Total Inbound Truck & $\underline{23,668.41}$ & $\underline{26,634.35}$ & $\underline{28,180.20}$ & $\underline{19.1 \%}$ \\
Outbound Truck: Ethanol & 445.4 & $10,793.9$ & $10,048.7$ & $2155.9 \%$ \\
Outbound Truck: DDGS & 637.8 & 537.7 & $1,169.2$ & $83.3 \%$ \\
Outbound Truck: Corn & $6,166.7$ & $3,817.8$ & $4,952.6$ & $-19.7 \%$ \\
Outbound Truck: Beans & $\underline{1,712.9}$ & $\underline{828.2}$ & $\underline{1,094.6}$ & $\underline{-36.1 \%}$ \\
Total Outbound Truck & $8,962.9$ & $15,977.7$ & $17,265.2$ & $92.6 \%$ \\
Total Truck Loads & $32,631.34$ & $42,612.04$ & $45,445.39$ & $39.3 \%$ \\
\hline
\end{tabular}

Overall, inbound truckloads within Indiana remain fairly constant with a 3.7 percent increase from 1.85 to 1.91 million loads from 2006 to 2010 (Table 3.14), while annual VMTs increase 19.1 percent, from 23.69 to 28.18 million miles (Table 3.15). Although this is not a large overall change, major changes occur across commodity types. Annual truckloads of corn to livestock decrease 18.4 percent, which account for a decline in VMTs of 532,400 miles, or 42.0 percent from 2006 to 2010. A major shift occurs as corn previously transported to elevators is shifted to ethanol plants. From 2006 to 2010, annual truckloads of corn to ethanol plants increase from 39,600 to 410,600 (936 percent), leading to an increase in VMTs from 696,000 miles to 6.03 million miles (767 percent). Annual elevator truckloads of corn to elevators decreased from 860,500 to 625,800 loads (a fall of 27.3 percent), which decrease VMTs from 7.26 to 5.26 million miles (a fall of 27.5 percent). 
A shift also occurs between soybeans transported to elevators and crushing facilities. Annual truckloads of soybeans to crushers increase by 36.2 percent, from 209,700 to 285,600 (Table 3.14) and VMTs from 5.07 to 7.83 million (54.62 percent) miles from 2006 to 2010 (Table 3.15). During this time, annual truckloads of soybeans to elevators decreased from 216,800 to 120,000 (-44.6 percent) and VMTs from 1.93 to 1.02 million miles (-47.0 percent).

Total outbound truckloads increase by 48.8 percent, from 172,500 to 256,700 from 2006 to 2010 (Table 3.14). Additionally, total outbound annual VMT almost double from 8.96 to 17.26 million miles (114.8 percent) during this time (Table 3.15 ). This can be attributed to less outbound grain and more outbound ethanol and DDGS, which travel further to their respective destination markets. From 2006 to 2010, annual outbound truckloads of corn decrease from 112,500 to 96,500 and soybeans from 39,500 to 28,500 . VMTs decrease from 6.17 to 4.95 million and 1.71 to 1.09 million miles for corn and soybeans, respectively. This decrease is compensated by the increase in loads of ethanol and DDGS. Truckloads of ethanol rise from 12,700 to 96,600 , while truckloads of DDGS increase from 7,800 to 35,000 . VMTs for ethanol rise from .45 to 10.05 million, while VMTs for DDGS rise from 637,800 to 1.17 million miles.

Total annual outbound rail carloads decrease from 161,812 to 143,108 from 2006 to 2010 (Table 3.14). However, there is a shift from outbound rail movements from grain to ethanol and DDGS. Rail carloads of corn decline from 126,500 to 85,750 and soybeans from 34,250 to 21,250 rail carloads. Ethanol rail tanker loads increased from 0 in 2006 to 10,620 in 2010, while DDGS increased from 0 rail hopper car loads in 2006 to 25,488 in 2010. 


\subsection{Results for Counties with Biofuels Plants}

Changes between each model year are due in large part to the addition of ethanol and biodiesel plants. Thus, it is likely that a large portion of the change that occurs between each year is concentrated in counties in which biofuels plants are constructed. Data are evaluated on changes in truckloads and VMTs for 13 counties (Cass, Grant, Henry, Jasper, Jay, Kosciusko, Madison, Montgomery, Posey, Putnam, Randolph, Wabash, and Wells) that added new ethanol and biodiesel plants between 2006 and 2010 to determine whether transportation impacts are concentrated (Figure 3-1.) Changes in truckloads and VMTs for the counties with new biofuels plants are compared against counties in the rest of the state. Miles and loads are credited to the county that originates the shipment. Thus, the results underestimate the effects on counties with new biofuels plants.

Total inbound truckloads fell by 54,400 loads in counties with new biofuels plants and by rose by 123,100 loads in the rest of the state (Table 3.16 ). In the counties with new plants, loads of corn and beans shifted from elevators to ethanol and biodiesel plants. Loads to ethanol plants also drove the traffic shift in the rest of the state. Overall, 41.9 and 22.3 percent of the loads to the new ethanol and biodiesel plants, respectively, came from the host counties. The rest of the state also saw a increase in shipments to biofuels plants that was offset by fewer loads to livestock and grain elevators. In addition, patterns to serve food plants change, with roughly 30,000 loads shifting from counties with new biofuels plants to the rest of the state.

Total inbound VMTs rose by 1.27 million miles in counties with new biofuels plants, and 3.2 million miles in the rest of the state (Table 3.17). The change in VMTS was driven by trips 
Table 3.16. Annual Inbound Truckloads for Counties with New Biofuels Plants

\begin{tabular}{|c|c|c|c|c|c|}
\hline \multirow{2}{*}{$\begin{array}{l}\text { Inbound Trucks Within } \\
\text { Indiana (Thousands) }\end{array}$} & \multicolumn{2}{|c|}{ Model } & \multicolumn{2}{|c|}{ Change in Truckloads 06 to 10} & \multirow{2}{*}{$\begin{array}{c}2010 \% \text { of Truck } \\
\text { Traffic in New } \\
\text { Biofuels Counties }\end{array}$} \\
\hline & 2006 & 2010 & $\begin{array}{c}\text { New Biofuels } \\
\text { Counties }\end{array}$ & Rest of State & \\
\hline Corn to Livestock & 55.8 & 47.1 & -8.8 & -37.2 & $23.0 \%$ \\
\hline Corn to Food & 38.2 & 8.1 & -30.1 & 29.4 & $3.0 \%$ \\
\hline Corn to Ethanol & 0.0 & 169.7 & 169.7 & 201.3 & $41.3 \%$ \\
\hline Corn to Elevator & 199.3 & 27.3 & -172.0 & -62.8 & $4.4 \%$ \\
\hline Beans to Crusher & 34.7 & 63.7 & 29.1 & 46.9 & $22.3 \%$ \\
\hline Beans to Elevator & $\underline{52.0}$ & $\underline{9.8}$ & -42.3 & $\underline{-54.5}$ & $\underline{8.1 \%}$ \\
\hline Total & 379.9 & 325.5 & -54.4 & 123.1 & $17.0 \%$ \\
\hline
\end{tabular}

Table 3.17. Annual Inbound VMT for Counties with New Biofuels Plants

\begin{tabular}{|c|c|c|c|c|c|}
\hline \multirow{2}{*}{$\begin{array}{l}\text { Inbound VMT Within } \\
\text { Indiana (000 miles) }\end{array}$} & \multicolumn{2}{|c|}{ Model } & \multicolumn{2}{|c|}{ Change in VMTs 06 to 10} & \multirow{2}{*}{$\begin{array}{c}2010 \% \text { of Truck } \\
\text { Traffic in New } \\
\text { Biofuels Counties }\end{array}$} \\
\hline & 2006 & 2010 & $\begin{array}{c}\text { New Biofuels } \\
\text { Counties }\end{array}$ & $\begin{array}{l}\text { Rest of } \\
\text { State }\end{array}$ & \\
\hline Corn to Livestock & 280.3 & 183.8 & -96.5 & -435.9 & $25.0 \%$ \\
\hline Corn to Food & $1,057.1$ & 239.6 & -817.5 & 665.7 & $3.3 \%$ \\
\hline Corn to Ethanol & 0.0 & $3,063.3$ & $3,063.3$ & $2,272.4$ & $50.8 \%$ \\
\hline Corn to Elevator & $1,682.2$ & 198.4 & $-1,483.8$ & -515.9 & $3.8 \%$ \\
\hline Beans to Crusher & 870.8 & $1,870.5$ & 999.7 & $1,766.2$ & $23.9 \%$ \\
\hline Beans to Elevator & $\underline{487.4}$ & $\underline{92.6}$ & $\underline{-394.8}$ & $\underline{-511.2}$ & $\underline{9.1 \%}$ \\
\hline Total & $4,377.8$ & $5,648.2$ & $1,270.5$ & $3,241.3$ & $20.0 \%$ \\
\hline
\end{tabular}

to ethanol plants ( 3 million new miles) and oil crushers ( 1 million new miles). This increase led to a decrease of 1.8 million miles to country elevators in counties with new biofuels plants. In the rest of the state, VMTs rose by 4.7 million miles to food processors and biofuels plants. Again, part of these miles are in fact traveled in the counties with the new plants.

Compared to the 1.9 million inbound shipments by truck, there are only 256,700 outbound movements (Table 3.14). In part this explained that inbound loads of corn and 
soybeans are shipped out of state by rail or barge. With the growth of the biofuels industry in Indiana, outbound truckloads increased by 94,400 loads in counties with new plants, but fell by 10,200 loads in the rest of the state (Table 3.18). The greatest increase in outbound truckloads came from the ethanol market with 83,900 new loads and DDGS with 31,500 loads. Overall, the counties with new biofuels plants account for 46.6 percent of outbound truckloads.

Table 3.18. Annual Outbound Trucks from Indiana for Counties with New Biofuels Plants

\begin{tabular}{|c|c|c|c|c|c|}
\hline \multirow{2}{*}{$\begin{array}{l}\text { Outbound Trucks } \\
\text { From Indiana } \\
\text { (Thousands) }\end{array}$} & \multicolumn{2}{|c|}{ Model } & \multicolumn{2}{|c|}{ Change in Truckloads 06 to 10} & \multirow{2}{*}{$\begin{array}{c}2010 \% \text { of Truck } \\
\text { Traffic in New } \\
\text { Biofuels Counties }\end{array}$} \\
\hline & 2006 & 2010 & $\begin{array}{c}\text { New Biofuels } \\
\text { Counties }\end{array}$ & Rest of State & \\
\hline Ethanol & 0.0 & 83.9 & 83.9 & 0.0 & $86.8 \%$ \\
\hline DDGS & 0.0 & 31.5 & 31.5 & -4.2 & $89.9 \%$ \\
\hline Corn From Elevators & 19.8 & 2.8 & -17.0 & 1.0 & $2.8 \%$ \\
\hline Beans From Elevators & $\underline{5.5}$ & $\underline{1.5}$ & $\underline{-4.0}$ & $\underline{-7.0}$ & $\underline{5.3 \%}$ \\
\hline Total & 25.3 & 119.7 & $\overline{94.4}$ & $-\overline{-10.2}$ & $4 \overline{6.6 \%}$ \\
\hline
\end{tabular}

The 13 counties with new ethanol and biodiesel plants are the source for 64.0 percent of the VMTs for outbound truck movements from Indiana (Table 3.19). Virtually all of the traffic to out-of-state destinations is ethanol to blenders in border states. VMTs rose from 1.7 million to 11.1 million miles in the counties with new plants, while they fell in the rest of the state by 1 million miles. DDGS miles in the rest of the state fell because livestock feeders in Indiana can source DDGS from ethanol plants near their operation in 2010, while in 2006 the only source was the ethanol plant in St. Joseph County. 
Table 3.19. Annual Outbound VMT for Counties with New Biofuels Plants

\begin{tabular}{|c|c|c|c|c|c|}
\hline \multirow{2}{*}{$\begin{array}{l}\text { Outbound VMTs From } \\
\text { Indiana (000 miles) }\end{array}$} & \multicolumn{2}{|c|}{ Model } & \multicolumn{2}{|c|}{ Change in VMTs 06 to 10} & \multirow{2}{*}{$\begin{array}{l}2010 \% \text { of } \\
\text { Truck Traffic in } \\
\text { New Biofuels } \\
\text { Counties }\end{array}$} \\
\hline & 2006 & 2010 & $\begin{array}{l}\text { New Biofuels } \\
\text { Counties }\end{array}$ & $\begin{array}{l}\text { Rest of } \\
\text { State }\end{array}$ & \\
\hline Ethanol & 0.0 & $9,687.9$ & $9,687.9$ & -84.6 & $96.4 \%$ \\
\hline DDGS & 0.0 & $1,072.0$ & $1,072.0$ & -540.7 & $91.7 \%$ \\
\hline Corn From Elevators & $1,373.1$ & 212.2 & $-1,160.9$ & -53.2 & $4.3 \%$ \\
\hline Beans From Elevators & $\underline{356.5}$ & $\underline{83.2}$ & $\underline{-273.3}$ & $\underline{-345.0}$ & $7.6 \%$ \\
\hline Total & $1,729.5$ & $11,0 \overline{55.2}$ & $9,325.7$ & $-1,023.4$ & $64.0 \%$ \\
\hline
\end{tabular}

Ethanol begins being shipped via rail in the 2010 model going from 0 annual rail carloads in 2006 to 10,600 thousand in 2010 (Table 3.20). Likewise, DDGS is shipped by rail starting in 2006 going from 0 annual carloads to 23,000 in 2010. Rail carloads of corn from the counties with new biofuels plants decrease 26,800 car loads. Overall, the counties with new ethanol and biodiesel plants represent 27.5 percent of the outbound rail traffic.

Table 3.20. Annual Outbound Rail Carloads from Counties with Biofuels Plants

\begin{tabular}{|c|c|c|c|c|c|}
\hline \multirow{2}{*}{$\begin{array}{l}\text { Outbound Rail } \\
\text { Carloads From Indiana } \\
\text { (Thousands) }\end{array}$} & \multicolumn{2}{|c|}{ Model } & \multicolumn{2}{|c|}{ Change in Rail Cars 06 to 10} & \multirow{2}{*}{$\begin{array}{l}2010 \% \text { of Truck } \\
\text { Traffic in New } \\
\text { Biofuels Counties }\end{array}$} \\
\hline & 2006 & 2010 & $\begin{array}{c}\text { New Biofuels } \\
\text { Counties }\end{array}$ & Rest of State & \\
\hline Ethanol & 0.0 & 10.6 & 10.6 & 0.0 & $100.0 \%$ \\
\hline DDGS & 0.0 & 23.0 & 23.0 & 1.4 & $90.3 \%$ \\
\hline Corn From Elevators & 31.0 & 4.3 & -26.8 & -14.0 & $5.0 \%$ \\
\hline Beans From Elevators & $\underline{9.3}$ & 1.5 & $\underline{-7.8}$ & -5.3 & $7.1 \%$ \\
\hline Total & 40.3 & 39.4 & -0.9 & -17.8 & $27.5 \%$ \\
\hline
\end{tabular}




\subsection{Results for Counties Adjacent to Biofuels Production Counties}

Much of the statewide change is observed in counties with new biofuels plants. Yet draw areas for these plants extend into adjacent counties. As a result, transportation systems in these counties are also likely affected. Therefore, changes for inbound and outbound truckloads, VMTs, and rail loadings are analyzed for four classifications of counties. The first group consists of the thirteen counties home to new biofuels plants since 2006 (Figure 3-1). Second, results are also considered for seven counties with existing food processing plants (classified as incumbents) because they continue to be large destinations for shipments. Finally, the other 72 counties are classified 32 border counties to counties with new plants or as the 40 other counties. As before, miles and loads are attributed to origin county. In addition, loads to food, ethanol and biodiesel plants in Indiana from the 39 counties in Illinois, Michigan, Ohio, and Kentucky that border Indiana are included.

With respect to inbound truckloads, the Border and Other counties account for almost 60 percent of the inbound truckloads generated in 2010 (Table 3.21). Corn and bean processors source 8.5 percent of their inbound loads from other states by truck. While the counties with new biofuels plants generate 17 percent of the inbound truckloads, they are responsible for 46.6 percent of the outbound loads of corn, beans, ethanol, and DDGS. The seven incumbent counties likely generate significant outbound truckloads of food based products. Rail car shipments are split across the New Plant, Border and Other Counties, with shipments of DDGS and ethanol from the New Plant counties and grain from the Border and Other counties. 
Table 3.21. Annual Distribution of Loads, By Type of County, 2010

\begin{tabular}{lcrrrrr}
\hline County Type & $\begin{array}{c}\text { Truckloads } \\
\text { In }\end{array}$ & $\begin{array}{c}\text { \% of } \\
\text { Trucks In }\end{array}$ & $\begin{array}{c}\text { Truckloads } \\
\text { Out }\end{array}$ & $\begin{array}{c}\text { \% of Trucks } \\
\text { Out }\end{array}$ & $\begin{array}{c}\text { Rail Cars } \\
\text { Out }\end{array}$ & $\begin{array}{r}\text { \% of Rail } \\
\text { Cars Out }\end{array}$ \\
\hline New & 329,295 & $17.2 \%$ & 119,654 & $46.6 \%$ & 40,380 & $28.2 \%$ \\
Incumbent & 110,117 & $5.8 \%$ & 18,534 & $7.2 \%$ & 4,978 & $3.5 \%$ \\
Border New & 755,938 & $39.5 \%$ & 41,500 & $16.2 \%$ & 56,000 & $39.1 \%$ \\
Other & 557,300 & $29.1 \%$ & 77,000 & $30.0 \%$ & 41,750 & $29.2 \%$ \\
Out of State & 161,840 & $8.5 \%$ & $\underline{0}$ & $0.0 \%$ & 0 & $\frac{0.0 \%}{100}$ \\
Total & $1,914,490$ & $100.0 \%$ & 256,688 & $100.0 \%$ & 143,108 & $100.0 \%$ \\
\hline
\end{tabular}

On a basis of VMTs, the distribution of inbound truckloads mirrors the distribution of truckloads. VMTs from Out of State origins are higher, which makes sense given the longer length of haul to Indiana food processors and biofuels plants. For outbound VMTs, the 13 counties with New Plants account for 64 percent of the annuals miles generated (Table 3.22.)

Table 3.22. Annual Distribution of VMTs, By Type of County, 2010

\begin{tabular}{lrrrr}
\hline County Type & \multicolumn{1}{c}{$\begin{array}{c}\text { VMTS for } \\
\text { Inbound }\end{array}$} & $\begin{array}{c}\text { \% of VMT for } \\
\text { Inbound }\end{array}$ & $\begin{array}{c}\text { VMTS for } \\
\text { Outbound }\end{array}$ & $\begin{array}{c}\text { \% of VMT for } \\
\text { Outbound }\end{array}$ \\
\hline New & $4,273.6$ & $15.2 \%$ & $11,055.2$ & $64.0 \%$ \\
Incumbent & $1,169.7$ & $4.2 \%$ & 658.0 & $3.8 \%$ \\
Border New & $11,374.6$ & $40.4 \%$ & $2,459.1$ & $14.2 \%$ \\
Other & $7,057.3$ & $25.0 \%$ & $3,092.9$ & $17.9 \%$ \\
Out of State & $4,304.9$ & $15.3 \%$ & $0.0 \%$ & 0.0 \\
Total & $28,180.2$ & $100.0 \%$ & $17,265.2$ & $100.0 \%$ \\
\hline
\end{tabular}

Finally, the change from 2006 to 2010 in loads and VMTs are considered by type of county for each type of inbound truck movement (corn to livestock, food processing, ethanol or elevators, and beans to crushers and elevators), outbound truck and rail movements of corn 
and beans from elevators and DDGS and ethanol from ethanol plants. Inbound truckloads fall from 2006 to 2010 for counties with New Plants. In contrast to all other types of counties, inbound truck movements only decrease in counties with New Plants (Table 3.23). However, the increase in truckloads in Border and Other Counties ends up traversing roads in counties with New Plants. In contrast, the increase in annual outbound truckloads is largely driven by additional shipments of ethanol and DDGS. For rail shipments, the decline in total cars comes largely from the reduction in shipments of corn and beans, especially from Border Counties.

Table 3.23. Net Change in Annual Loads from 2006 to 2010, by Type of County

\begin{tabular}{|c|c|c|c|c|c|c|}
\hline \multirow[t]{2}{*}{ Use/Mode } & \multicolumn{6}{|c|}{ Type of County Originating Shipment (in 000 loads per year) } \\
\hline & New & Incumbent & Border & Other & Out of State & Total \\
\hline Inbound Truckloads & \multicolumn{6}{|c|}{ (in 000 loads per year) } \\
\hline Livestock & -8.8 & -1.8 & -14.6 & -20.8 & 0.0 & -46.0 \\
\hline Food & -30.1 & 2.1 & 8.1 & 10.2 & 9.1 & -0.7 \\
\hline Ethanol & 173.5 & 9.2 & 125.7 & -2.8 & 65.5 & 371.0 \\
\hline Elevator & -172.0 & -1.0 & -102.8 & 41.0 & 0.0 & -234.8 \\
\hline Crusher & 29.1 & 6.3 & 23.5 & 7.4 & 9.8 & 76.0 \\
\hline Elevator & $\underline{-42.3}$ & $\underline{-10.0}$ & $\underline{-32.3}$ & $\underline{-12.3}$ & $\underline{0.0}$ & -96.8 \\
\hline Total Inbound Truck & $\overline{-50.6}$ & $\overline{4.8}$ & $\overline{7.6}$ & $\overline{22.6}$ & $8 \overline{4.4}$ & $\overline{68.8}$ \\
\hline Outbound Truckloads & \multicolumn{6}{|c|}{ (in 000 loads per year) } \\
\hline Corn & -17.0 & -0.8 & -7.3 & 9.0 & 0.0 & -16.0 \\
\hline Beans & -4.0 & -3.3 & -2.3 & -1.5 & 0.0 & -11.0 \\
\hline Ethanol & 83.9 & 0.0 & 0.0 & 0.0 & 0.0 & 83.9 \\
\hline DDGS & $\underline{31.5}$ & $\underline{-4.2}$ & $\underline{0.0}$ & $\underline{0.0}$ & $\underline{0.0}$ & $\underline{27.3}$ \\
\hline Total Outbound Truck & $\overline{94.4}$ & $\overline{-8.2}$ & $-\overline{9.5}$ & $\overline{7.5}$ & $\overline{0.0}$ & $\overline{84.2}$ \\
\hline Outbound Rail loads & \multicolumn{6}{|c|}{ (in 000 loads per year) } \\
\hline Corn & -26.8 & -0.3 & -17.0 & 3.3 & 0.0 & -40.8 \\
\hline Beans & -6.8 & -0.5 & -3.8 & -2.0 & 0.0 & -13.0 \\
\hline Ethanol & 10.6 & 0.0 & 0.0 & 0.0 & 0.0 & 10.6 \\
\hline DDGS & 23.0 & 1.4 & 0.0 & 0.0 & 0.0 & 24.4 \\
\hline Total Rail & $\overline{0.1}$ & $\overline{0.7}$ & -20.8 & $\overline{1.3}$ & $\overline{0.0}$ & $\overline{-18.7}$ \\
\hline
\end{tabular}


With respect to inbound traffic, the increase in total VMTs is largely driven by more miles to ethanol and crushers among all types of counties (Table 3.24). This increase is offset by fewer inbound miles among all types of counties to grain elevators. In addition, counties with new plants ship less corn to food processors, choosing to use the corn to manufacture ethanol. This loss is offset by an increase in VMTs from all other types of counties to food processors. The increase of 8.3 million VMTs is again driven by shipments of ethanol and DDGS from the New Plant counties. The only other outbound increase in VMTs occurs for corn shipped from the Other Counties.

Table 3.24. Net Change in Annual VMTs from 2006 to 2010, by Type of County

\begin{tabular}{|c|c|c|c|c|c|c|}
\hline Use/Mode & New & Incumbent & Border & Other & Out of State & Total \\
\hline Inbound Truckloads & \multicolumn{6}{|c|}{ (in 000 miles per year) } \\
\hline Livestock & -96.5 & -29.7 & -140.9 & -265.3 & 0.0 & -532.4 \\
\hline Food & -817.5 & 7.5 & 129.1 & 236.5 & 292.5 & -151.8 \\
\hline Ethanol & $1,688.7$ & 161.5 & $2,136.9$ & -58.0 & $1,406.6$ & $5,335.7$ \\
\hline Elevator & $-1,483.8$ & -11.9 & -925.5 & 421.5 & 0.0 & $-1,999.7$ \\
\hline Crusher & 999.7 & 227.6 & 773.1 & 292.4 & 473.1 & $2,766.0$ \\
\hline Elevator & $\underline{-394.8}$ & $\underline{-94.3}$ & $\underline{-291.4}$ & -125.4 & $\underline{0.0}$ & $\underline{-905.9}$ \\
\hline Total Inbound & -104.1 & 260.6 & $1,681.3$ & 501.7 & $2,172.2$ & $4,511.8$ \\
\hline Outbound Truckloads & \multicolumn{6}{|c|}{ (in 000 miles per year) } \\
\hline Corn & $-1,160.9$ & -40.3 & -614.3 & 601.5 & 0.0 & $-1,214.1$ \\
\hline Beans & -273.3 & -183.4 & -115.5 & -46.0 & 0.0 & -618.3 \\
\hline Ethanol & $9,687.9$ & -84.6 & 0.0 & 0.0 & 0.0 & $9,603.2$ \\
\hline DDGS & $\underline{1,072.0}$ & $\underline{-540.7}$ & $\underline{0.0}$ & $\underline{0.0}$ & $\underline{0.0}$ & $\underline{531.4}$ \\
\hline Total Outbound & $\overline{9,325.7}$ & $\overline{-849.1}$ & $-72 \overline{9.8}$ & $55 \overline{5.4}$ & $\overline{0.0}$ & $8, \overline{302.3}$ \\
\hline
\end{tabular}


County level VMTS are provided for each county in Appendix A. Figure 3.2 shows the top 10 counties in terms of VTMS for 2006 and 2010. The panel for 2010, also shows the counties with the top 10 percentage changes in VTM.

Figure 3-2. Top Ten Counties for VMTs, 2006 and 2010
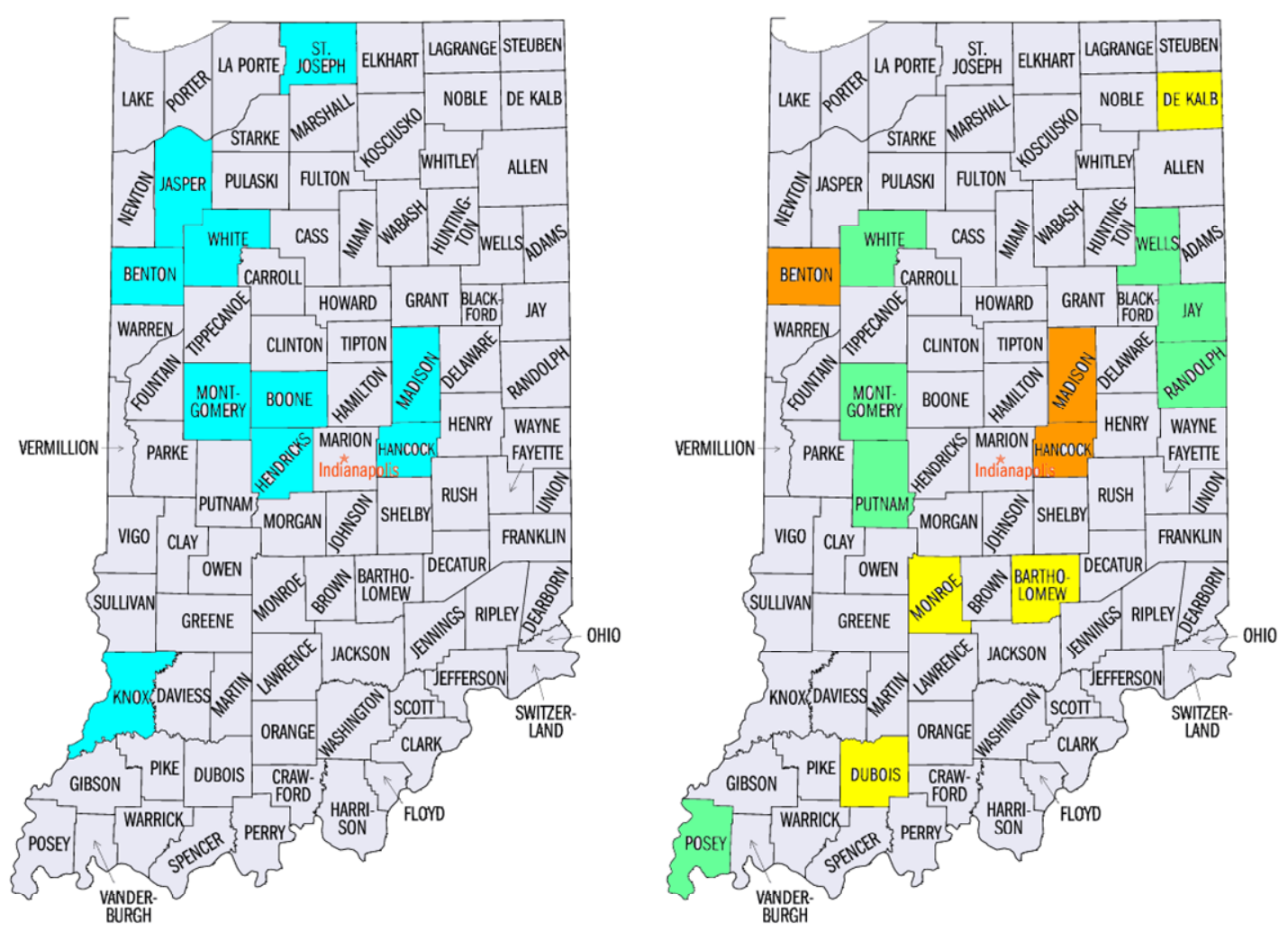

\begin{tabular}{|c|c|}
\hline Top 10 VMT in 2006 & Top $10 \%$ change in VMTs \\
\hline Top 10 VMT in 2010 & Both Top 10 VMT and \% Change \\
\hline
\end{tabular}




\section{Chapter 4 - Summary and Conclusions}

\subsection{Overview}

Ethanol and biodiesel producers constantly deal with transportation issues from allocating feedstock to shipping end products to destination points. The addition of more ethanol plants can lead to cases of congestion on rural roads. The objective of this analysis is to determine how the entry of biofuel plants affects inbound and outbound transportation flows of corn, soybeans, DDGS, and ethanol at the county level in Indiana. To accomplish this, transportation flows of corn, soybeans, ethanol, and DDGS were examined for three time periods, 2006 (baseline), 2008 (short term), and 2010 (long term).

The U.S. biofuels industry has experienced rapid growth since 2005. The ethanol industry alone has increased production capacity from just over 1 billion gallons in 1997 to nearly 12.5 billion in spring 2009. Further expansion is an open question that will depend on political decisions as much as economic ones. Ethanol production in the state of Indiana has the potential to grow to over 1 billion by 2010 . Growth in this industry has provided opportunities not only to the biofuels industry but also to agriculture and transportation industries.

Additional demand for grain from biofuels expansion affects decisions farmers must make. Rather than shipping grain short distances to country elevators, they have an additional option of shipping grain direct to biofuels plants which could mean longer haul distances. This means less grain will be handled by elevators and that grain will be shipped through new 
transportation routes to biofuels plants. End users of ethanol and DDGS also will be affected. Much more of both products in terms of volume has become available.

As more grain is hauled to biofuels plants, and more ethanol and DDGS is transported to demand points, it is apparent that transportation routes will likely be altered which farmers, ethanol producers, and elevator operators will adapt to. The addition of biofuels plants also presents an opportunity for rural economic development as more grain is transported to biofuels plants change. Policy makers have the opportunity to give careful thought as how to best plan for expansion in this industry such that possible transportation concerns can be addressed and rural economic development can occur.

\subsection{Model and Results}

Distance minimizing transportation linear programming models were developed to allocate grain, ethanol, and DDGS among production and consumption points. Output from these models was then used in an Excel spreadsheet model to estimate transportation requirements at the county level for corn, soybeans, ethanol, and DDGS. This procedure was performed at the county level for all counties in Indiana. The models described were used for three separate time periods (2006, 2008, and 2010) using forecasted data when necessary. End results from the Excel spreadsheet model include truckloads, VMTs, average $\mathrm{LOH}$, and rail carloads required to transport each commodity. Results were calculated at the county level for every county in Indiana. Because the major change between time periods is the addition of biofuels plants, the difference in results between each year can be largely attributed to ethanol expansion in Indiana. 


\subsection{Conclusions}

Three main conclusions that are identified based on results from this research:

1. Truck traffic in Indiana associated with grain, ethanol, and DDGS movements will increase by 12.8 million VMT or 39.3 percent due to the expansion of a biofuels industry.

2. Elevators will handle 31 percent less grain.

3. The rail industry will have less grain to handle, but more ethanol and DDGS.

Results show that both statewide total truckloads and VMT increase between each time period with most of this change occurring in counties with biofuels plants and adjacent counties. Results also show that truckloads of grain to elevators decline between each period. These results imply that a shift is occurring from grain being shipped to elevators to grain being shipped directly to biofuels plants. Compared to elevators, biofuels plants average LOH for grain is further by approximately 10 miles per load. This means that grain is being transported by truck further distance in 2008 and 2010 than in 2006. Although it is not entirely clear from this research which roads will be most affected, it is likely that some of the increased truck traffic will occur on secondary roads given the rural nature of grain production and biofuels plant location in Indiana.

Furthermore, as more grain is transported directly to biofuels plants and less to elevators, transportation flows of corn will also change. Historically, grain transported to elevators usually maintains similar transportation flows year to year. Shipments of grain to elevators are also very seasonal being concentrated during grain harvest season. Because biofuels plants demand grain consistently throughout the year, grain transportation traffic will 
be less seasonal compared to elevator grain flows. This means routes taken by trucks will likely be new transportation routes and will incur truck traffic more consistently throughout the year.

The results show a significant decline in bushels of corn, approximately 140 million bushels, and soybeans, approximately 59 million bushels, transported to elevators. With most elevators running on small profit margins per bushel of grain handled, a large reduction in volume of grain going through an elevator could lead to significant affects in profits generated by elevators. Although this study does not examine the direct effects of biofuels production on elevator profitability, it is possible to infer that some elevators could be shut down due to the reduction in grain handled by elevators. From results from this study, it also remains uncertain what role elevators will have during biofuels expansion. It is quite possible the affects of biofuels expansion experienced by elevators throughout the state will be determined by several factors. One possible factor is an elevator's location in proximity to a biofuels plant. One possibility is that biofuels plants may not have sufficient storage capabilities on site which provides opportunity for nearby elevators to assist with grain movements to the plant. Elevators located further away may not have this opportunity.

A decline in grain being shipped to elevators also means that less grain will be transported from elevators out of state. Truckloads transporting grain from elevators out of Indiana usually travel longer distances compared to trucks delivering corn to processing plants and elevators. A reduction in truckloads from elevators means less long haul truckloads within Indiana. However, a majority of grain leaving Indiana from elevators happens via rail which means the rail industry will be affected as well. 
Results show a reduction in rail carloads of grain leaving Indiana but an increase in loads of ethanol and DDGS. This means that the reduction in grain being transported by rail is partially offset by the increase in ethanol and DDGS. Combined loads of corn, soybeans, ethanol, and DDGS decline by 11.6 percent from 2006 to 2010 . Additionally, transportation of grain by rail is seasonal where ethanol and DDGS most likely will not be. Although the change in total loads is relatively small, the rail industry will need to adapt to differences in transporting ethanol and DDGS rather than grain. It should be noted that both ethanol and DDGS have issues in being transported by rail. Unit train receiving destination points for ethanol are limited, therefore logistical constraints will likely play a factor in ethanol shipments by rail. DDGS is very bulky in nature and solidifies in rail cars during transport. This increases the time and labor requirement to load and unload cars with DDGS. The results of this study do not take these factors into account and it remains unclear exactly how this will affect rail transportation.

\subsection{Caveats}

As with any model, the results of this model are a product of the assumptions made. Assumptions made in this research with regard to truck capacities leave room for further development. For example, it is not likely that all trucks delivering grain to food processing and ethanol plants have a 920 bushel capacity, but rather are a mix of different capacity trucks. This is true for all inbound grain and outbound grain, ethanol, and DDGS trucks. Incorporating a more accurate distribution of different truck capacities will provide more accurate calculations for truckloads and miles. Different truck sizes also damage roadways differently. A more 
accurate estimation of truckloads and VMT for different truck sizes allows for the possibility of better analyzing road damage and upkeep requirements due to biofuels expansion.

The assumption that ethanol and DDGS truck markets are satisfied before rail shipments are considered is made in this research. Many ethanol plants being constructed in Indiana have rail access. Therefore, it is likely they will use rail access regardless of truck market demand. It is more likely that the decision to ship outbound ethanol and DDGS will be based primarily on costs and price offered by a demand location. If a gasoline blending terminal is offering higher prices for ethanol and the costs to transport via rail are competitive relative to the truck market, then an ethanol plant is likely to engage in rail shipments regardless of the status of truck market demand. Further research could incorporate a decision variable that incorporates ethanol and DDGs prices, transport costs, and location in terms of rail and highway access to determine the distribution of outbound rail and truck shipments of ethanol and DDGS.

This research assumes historic cropping patterns will hold true through 2010. However, this research does not include the affects biofuels expansion has on crop prices which in turn could affect farmers' decisions on crop acreage. It remains unclear at this time exactly how the agriculture industry will adapt to increasing commodity prices (specifically corn and soybeans). As this research is used in the future, it should be known that results could be altered based on shifts in corn and soybean production acres.

This research examines inbound grain flows and outbound grain, ethanol, and DDGS on a county level basis and how the flows are affected when a biofuels plant is introduced. The results of this research indicate changes in transportation flows due to additional biofuels plants being constructed. However, it is difficult to examine the affects an individual plant has 
from the results. Future research could develop a similar model to this, but also examine an individual plant. This would help local transportation planners better prepare and allocate funds for infrastructure development and upkeep. It would also benefit ethanol plants in modeling and planning transportation modes.

The results from this research provide information about changes in terms of truckloads and VMT due to biofuels production. One shortcoming is this model does not address which roadways will be affected. Future research could incorporate Geographic Information Systems (GIS) to model which transportation routes are affected and which new transportation routes are taken. This would especially aid transportation planners in the future. However, given aggregate impacts and knowledge of plant locations, planners are able to make informed judgments in using information from this research to estimate local transportation infrastructure impacts. 


\section{Selected References}

American Coalition for Ethanol. 2007. "STAT US - A State by State Handbook." Sioux Falls, South Dakota. http://www.ethanol.org/pdf/contentmgmt/ACE120 Status 07 web-1.pdf.

Arora, S., M. Wu, and M. Wang. "Update of Distillers Grains Replacement Ratios for Corn Ethanol Life-Cycle Analysis. Center for Transportation Research, Argonne National Laboratory, Argonne, IL, http://www.transportation.anl.gov/pdfs/AF/527.pdf

Ballou, R. H. 2005. Business Logistics/Supply Chain Management: Planning, Organizing, and Controlling the Supply Chain, $5^{\text {th }}$ ed. New Jersey: Pearson Prentice Hall.

Berger, L.L. and D. L. Good. 2007. “Distillers Dried Grains Plus Solubles Utilization by Livestock and Poultry," in Corn-Based Ethanol in Illinois and the U.S. A Report from the Department of Agricultural and Consumer Economics, University of Illinois, Champaign-Urbana.

Biomass Research and Development Board. 2008. Increasing Feedstock Production for Biofuels: Economic Drivers, Environmental Implications, and the Role of Research. Washington, DC. http://www.usbiomassboard.gov/pdfs/8 Increasing Biofuels Feedstock Production.pdf

Bureau of Transportation Statistics. 2004. Indiana 2002 Economic Census - Transportation 2002 Commodity Flow Survey. EC02TCF-IN. U.S. Department of Transportation and U.S. Department of Commerce. Washington, DC. http://www.census.gov/prod/ec02/ec02tcfin.pdf.

Clean Fuels Development Coalition. 2007. Ethanol Fact Book. Bethesda, MD. http://www.cleanfuelsdc.org/pubs/documents/CFDC Fact\%20Book 1107.pdf

Collins, K. 2007. The New World of Biofuels: Implications for Agriculture and Energy. Washington, DC.

Cooper, G. 2005. "An Update on Foreign and Domestic Dry Grind Ethanol Coproducts Markets." National Corn Growers Association, Washington, DC. www.ncga.com/ethanol/pdfs/DDGSMarkets.pdf.

Denicoff, M.R. 2007. "Ethanol Transportation Backgrounder." Agricultural Marketing Service Transportation and Marketing Programs Transportation Services Branch. United States Department of Agriculture. Washington, DC. http://www.ams.usda.gov/tmd/TSB/EthanolTransportationBackgrounder09-17-07.pdf

Dooley, F.J. 2008a. "Market Analysis for Dried Distillers Grains in Indiana." Working Paper 08-11. Department of Agricultural Economics, Purdue University, West Lafayette, IN. http://purl.umn.edu/46340 
Dooley, F.J. 2008b. "U.S. Market Potential for Dried Distillers Grain with Solubles." Working Paper 08-12. Department of Agricultural Economics, Purdue University, West Lafayette, IN. http://purl.umn.edu/46342

Drevna, C. (2008). "Testimony - A Legislative Hearing on the Energy Market Effects of the Recently-Passed Renewable Fuel Standard." National Petrochemical \& Refiners Association, Washington, DC. http://www.npra.org/news/releases/DrevnaTestimony020708.pdf

Energy Information Administration. 2007a. "Energy and Economic Impacts of Implementing Both a 25-Percent RPS and a 25-Percent RFS by 2025." US Department of Energy, Washington, DC. http://www.eia.doe.gov/oiaf/servicerpt/eeim/issues.html.

Energy Information Administration. 2007b. "Map of Reformulated Gasoline." US Department of Energy, Washington, DC.

http://www.eia.doe.gov/oil_gas/petroleum/data_publications/wrgp/reformulated_map.ht $\mathrm{ml}$.

Energy Information Administration. 2009a. "Alternative Fueling Station Total Counts by State and Fuel Type". US Department of Energy, Washington, DC.

http://www.afdc.energy.gov/afdc/fuels/stations counts.html

Energy Information Administration. 2009b. "Annual Energy Outlook 2009 With Projections to 2030." US Department of Energy, Washington, DC. DOE/EIA-0383(2009) http://www.eia.doe.gov/oiaf/aeo/pdf/0383(2009).pdf

Energy Information Administration. 2009c. "Biodiesel Supply and Consumption in the Short-Term Energy Outlook." US Department of Energy, Washington, DC. http://www.eia.doe.gov/emeu/steo/pub/special/2009_sp_01.pdf

Energy Information Administration. 2009d. "Consumption, Price, and Expenditure Estimates." US Department of Energy, Washington, DC. http://www.eia.doe.gov/emeu/states/hf.jsp?incfile=sep_sum/plain_html/sum_btu_tra.ht $\mathrm{ml}$.

Energy Information Administration. 2009e. "Oxygenate Production." US Department of Energy, Washington, DC. http://tonto.eia.doe.gov/dnav/pet/hist/m_epooxe_yop_nus_1a.htm. http://www.eia.doe.gov/oiaf/aeo/pdf/appendixes.pdf2009e.

Energy Information Administration. 2009f. "Prime Supplier Sales Volumes." US Department of Energy, Washington, DC. http://tonto.eia.doe.gov/dnav/pet/pet_cons_prim_dcu_nus_a.htm 
Energy Information Administration. 2009g. "Refiner Acquisition Cost of Crude Oil." US

Department of Energy, Washington, DC.

http://tonto.eia.doe.gov/dnav/pet/pet_pri_rac2_dcu_nus_m.htm.

Energy Information Administration. 2009h. "Refinery \& Blender Net Production." US Department of Energy, Washington, DC.

http://tonto.eia.doe.gov/dnav/pet/pet_pnp_refp_dc_nus_mbbl_a.htm.

Energy Information Administration. 2009j. "Updates by Energy Source." US Department of Energy, Washington, DC.

http://www.eia.doe.gov/emeu/states/sep fuel/html/pdf/fuel use en.pdf

Environmental Protection Agency. 2008. "Renewable Fuel Standard Program." http://www.epa.gov/otaq/renewablefuels/

Gaffigan, M. 2007. "Biofuels - DOE Lacks a Strategic Approach to Coordinate Increasing Production with Infrastructure Development and Vehicle Needs." GAO-07-713. United States Government Accountability Office, Washington, DC. http://www.gao.gov/new.items/d07713.pdf

Gallagher, P., H. Shapouri, and H. Brubaker. 2007. "Scale, Organization, and Profitability of ethanol Processing. " Canadian Journal of Agricultural Economics. 55(1):63-81.

Gray, A. 2006. Is Biodiesel as Attractive an Economic Alternative as Ethanol? Purdue Extension BioEnergy Series ID 341, Purdue University, West Lafayette, IN, http://www.extension.purdue.edu/extmedia/ID/ID-341.pdf

Indiana Department of Agriculture. 2009. "Fact Sheet: Biofuels Plants in Indiana. Indianapolis, IN. http://www.in.gov/isda/biofuels/factsheet-biofuels-031009.pdf

Milling and Baking News. 2008. Index of Mills by Location, Type." Grain and Milling Annual. Special Publication. Sosland Publishing, Kansas City, MO.

Matthews, K.H. and M.J. McConnell. 2009. "Ethanol Co-Product Use in U.S. Cattle Feeding." FDS09D-01. Economic Research Service, USDA. http://www.ers.usda.gov/Publications/FDS/2009/04Apr/FDS09D01/FDS09D01.pdf

Muehlegger, E. 2006. "Market Effects of Regulatory Heterogeneity: A Study of Regional Gasoline Content Regulations." KSG Working Paper No. RWP06-021. http://ssrn.com/abstract=939649

National Biodiesel Board. 2009. Biodiesel-Commonly Asked Questions." http://www.biodiesel.org/pdf files/fuelfactsheets/CommonlyAsked.PDF 
National Agricultural Statistics Service. 2007. "Ethanol Co-Products Used for Livestock Feed." Sp Sy 6-1 (6-07). United States Department of Agriculture, Washington DC. http://usda.mannlib.cornell.edu/MannUsda/viewDocumentInfo.do?documentID=1756

National Agriculture Statistic Service. 2009. Indiana County Data-Crop and Livestock. US Department of Agriculture. http://www.nass.usda.gov/Statistics by State/Indiana/index.asp

Quear, J.L. 2008. "The Impacts of Biofuel Expansion on Transportation and Logistics in Indiana." M.S. Thesis, Department of Agricultural Economics, Purdue University, West Lafayette, IN.

Radich, A. 2007. "Biodiesel Performance, Costs, and Use." Energy Information Administration, Department of Energy, Washington, DC, http://tonto.eia.doe.gov/ftproot/environment/biodiesel.pdf

Renewable Fuels Association. 2009. "Legislative Actions: State." http://www.ethanolrfa.org/policy/actions/state/

Reynolds, R.E. 2002. "Infrastructure Requirements for an Expanded Fuel Ethanol Industry." Oak Ridge National Laboratory Ethanol Project, Oak Ridge, TN. http://www.ethanolrfa.org/objects/documents/94/dai.pdf

Sarmiento, C. and W.W. Wilson. 2008. "Spatial Competition and Ethanol Plant Location Decisions." Selected Paper, American Agricultural Economics Association 2008 Annual Meeting, Orlando, FL, http://purl.umn.edu/6175.

Searchinger, T. et al. 2008. "Use of U.S. Croplands for Biofuels Increases Greenhouse Gases Through Emissions from Land Use Change." Science Express Report. http://www.sciencemag.org/cgi/content/full/319/5867/1238

Sissine, F. 2007. "Energy Independence and Security Act of 2007: A Summary of Major Provisions." RL34294. Congressional Research Service, Washington, DC.

Tiffany, D.G. and V.R. Eidman. 2003. "Factors Associated With Success of Fuel Ethanol Producers." Staff Paper P03-7. Department of Applied Economics, University of Minnesota, St. Paul. http://purl.umn.edu/14155

United States Department of Agriculture. 2009a. "The 2007 Census of Agriculture." Washington, DC. http://www.agcensus.usda.gov/Publications/2007/Full Report/index.asp

United States Department of Agriculture. 2009b. Feed Grains Database: Custom Queries. Economic Research Service, Washington, DC. http://www.ers.usda.gov/Data/feedgrains/FeedGrainsQueriable.aspx 
Urbanchuk, J.M. 2003. "The Impact of Growing Ethanol Byproduct Production on Livestock Feed Markets." USDA Agriculture Outlook Forum 2003. http://purl.umn.edu/33115

Westcott, P.C. 2007 Ethanol Expansion in the United States How Will the Agricultural Sector Adjust? FDS-07D-01. Washington, DC, United States Department of Agriculture, Economic Research Service.

Westcott, P.C. 2009. USDA Agricultural Projections to 2018. OCE-2009-1. Washington, DC, United States Department of Agriculture, Economic Research Service. http://www.ers.usda.gov/Publications/OCE091/OCE091.pdf

Wu, M. 2008. "Analysis of the Efficiency of the U.S. Ethanol Industry 2007." Center for Transportation Research, Argonne National Laboratory, Argonne, IL, http://www1.eere.energy.gov/biomass/pdfs/anl ethanol analysis 2007.pdf

Yacobucci, B.D. and T. Capehart. 2008. "Selected Issues Related to an Expansion of the Renewable Fuel Standard (RFS)." CRS Report for Congress RL34265, Congressional Research Service, Washington, DC. http://www.nationalaglawcenter.org/assets/crs/RL34265.pdf 


\section{Appendix A - VTMS by County}

\begin{tabular}{|c|c|c|c|c|c|c|}
\hline \multirow{2}{*}{ County } & \multicolumn{3}{|c|}{ VTMS per Year } & \multicolumn{3}{|c|}{ \% Change in VTMS from: } \\
\hline & 2006 & 2008 & 2010 & 06 to 08 & 08 to 10 & 06 to 10 \\
\hline Adams & 207,558 & 166,650 & 178,656 & $-19.7 \%$ & $7.2 \%$ & $-13.9 \%$ \\
\hline Allen & 436,492 & 410,303 & 434,750 & $-6.0 \%$ & $6.0 \%$ & $-0.4 \%$ \\
\hline Bartholomew & 356,335 & 357,692 & 568,972 & $0.4 \%$ & $59.1 \%$ & $59.7 \%$ \\
\hline Benton & 676,875 & 708,898 & 790,347 & $4.7 \%$ & $11.5 \%$ & $16.8 \%$ \\
\hline Blackford & 84,069 & 107,732 & 114,109 & $28.1 \%$ & $5.9 \%$ & $35.7 \%$ \\
\hline Boone & 731,355 & $1,095,972$ & 569,068 & $49.9 \%$ & $-48.1 \%$ & $-22.2 \%$ \\
\hline Brown & 20,920 & 22,707 & 6,090 & $8.5 \%$ & $-73.2 \%$ & $-70.9 \%$ \\
\hline Carroll & 404,451 & 505,499 & 455,826 & $25.0 \%$ & $-9.8 \%$ & $12.7 \%$ \\
\hline Cass & 426,702 & $1,595,490$ & 510,688 & $273.9 \%$ & $-68.0 \%$ & $19.7 \%$ \\
\hline Clark & 84,924 & 100,764 & 90,788 & $18.7 \%$ & $-9.9 \%$ & $6.9 \%$ \\
\hline Clay & 269,599 & 247,976 & 244,652 & $-8.0 \%$ & $-1.3 \%$ & $-9.3 \%$ \\
\hline Clinton & 587,538 & 673,222 & 745,907 & $14.6 \%$ & $10.8 \%$ & $27.0 \%$ \\
\hline Crawford & 20,609 & 22,871 & 9,592 & $11.0 \%$ & $-58.1 \%$ & $-53.5 \%$ \\
\hline Daviess & 436,750 & 450,966 & 512,236 & $3.3 \%$ & $13.6 \%$ & $17.3 \%$ \\
\hline De Kalb & 180,664 & 251,266 & 287,359 & $39.1 \%$ & $14.4 \%$ & $59.1 \%$ \\
\hline Dearborn & 21,606 & 28,620 & 32,895 & $32.5 \%$ & $14.9 \%$ & $52.2 \%$ \\
\hline Decatur & 350,664 & 311,279 & 362,649 & $-11.2 \%$ & $16.5 \%$ & $3.4 \%$ \\
\hline Delaware & 452,254 & 278,571 & 333,692 & $-38.4 \%$ & $19.8 \%$ & $-26.2 \%$ \\
\hline Dubois & 316,993 & 413,317 & 503,045 & $30.4 \%$ & $21.7 \%$ & $58.7 \%$ \\
\hline Elkhart & 201,969 & 212,817 & 214,179 & $5.4 \%$ & $0.6 \%$ & $6.0 \%$ \\
\hline Fayette & 167,052 & 143,873 & 167,307 & $-13.9 \%$ & $16.3 \%$ & $0.2 \%$ \\
\hline Floyd & 10,561 & 12,960 & 12,917 & $22.7 \%$ & $-0.3 \%$ & $22.3 \%$ \\
\hline Fountain & 397,278 & 408,732 & 450,675 & $2.9 \%$ & $10.3 \%$ & $13.4 \%$ \\
\hline Franklin & 296,264 & 229,475 & 281,425 & $-22.5 \%$ & $22.6 \%$ & $-5.0 \%$ \\
\hline Fulton & 414,753 & 317,134 & 452,369 & $-23.5 \%$ & $42.6 \%$ & $9.1 \%$ \\
\hline Gibson & 485,899 & 523,088 & 517,848 & $7.7 \%$ & $-1.0 \%$ & $6.6 \%$ \\
\hline Grant & 422,535 & 753,742 & 441,233 & $78.4 \%$ & $-41.5 \%$ & $4.4 \%$ \\
\hline Greene & 260,943 & 204,853 & 219,264 & $-21.5 \%$ & $7.0 \%$ & $-16.0 \%$ \\
\hline Hamilton & 598,671 & 306,110 & 596,234 & $-48.9 \%$ & $94.8 \%$ & $-0.4 \%$ \\
\hline Hancock & 717,949 & 711,091 & 821,429 & $-1.0 \%$ & $15.5 \%$ & $14.4 \%$ \\
\hline Harrison & 133,122 & 119,105 & 134,079 & $-10.5 \%$ & $12.6 \%$ & $0.7 \%$ \\
\hline Hendricks & 611,416 & 662,928 & 734,041 & $8.4 \%$ & $10.7 \%$ & $20.1 \%$ \\
\hline Henry & 460,026 & 416,934 & 427,454 & $-9.4 \%$ & $2.5 \%$ & $-7.1 \%$ \\
\hline Howard & 338,842 & 323,729 & 365,808 & $-4.5 \%$ & $13.0 \%$ & $8.0 \%$ \\
\hline Huntington & 469,490 & 337,969 & 396,466 & $-28.0 \%$ & $17.3 \%$ & $-15.6 \%$ \\
\hline
\end{tabular}




\begin{tabular}{|c|c|c|c|c|c|c|}
\hline \multirow{2}{*}{ County } & \multicolumn{3}{|c|}{ VTMS per Year } & \multicolumn{3}{|c|}{ \% Change in VTMS from: } \\
\hline & 2006 & 2008 & 2010 & 06 to 08 & 08 to 10 & 06 to 10 \\
\hline Jackson & 209,038 & 184,680 & 199,556 & $-11.7 \%$ & $8.1 \%$ & $-4.5 \%$ \\
\hline Jasper & 803,900 & $1,077,306$ & 598,816 & $34.0 \%$ & $-44.4 \%$ & $-25.5 \%$ \\
\hline Jay & 319,236 & $1,837,187$ & $1,882,904$ & $475.5 \%$ & $2.5 \%$ & $489.8 \%$ \\
\hline Jefferson & 112,738 & 105,502 & 114,606 & $-6.4 \%$ & $8.6 \%$ & $1.7 \%$ \\
\hline Jennings & 240,140 & 229,555 & 235,877 & $-4.4 \%$ & $2.8 \%$ & $-1.8 \%$ \\
\hline Johnson & 474,046 & 448,005 & 530,876 & $-5.5 \%$ & $18.5 \%$ & $12.0 \%$ \\
\hline Knox & 699,305 & 669,914 & 761,634 & $-4.2 \%$ & $13.7 \%$ & $8.9 \%$ \\
\hline Kosciusko & 511,395 & 388,849 & 459,368 & $-24.0 \%$ & $18.1 \%$ & $-10.2 \%$ \\
\hline La Grange & 156,730 & 155,088 & 189,540 & $-1.0 \%$ & $22.2 \%$ & $20.9 \%$ \\
\hline La Porte & 587,921 & 679,443 & 709,294 & $15.6 \%$ & $4.4 \%$ & $20.6 \%$ \\
\hline Lake & 139,264 & 141,968 & 145,735 & $1.9 \%$ & $2.7 \%$ & $4.6 \%$ \\
\hline Lawrence & 84,645 & 73,843 & 86,898 & $-12.8 \%$ & $17.7 \%$ & $2.7 \%$ \\
\hline Madison & 654,915 & $1,884,891$ & 929,321 & $187.8 \%$ & $-50.7 \%$ & $41.9 \%$ \\
\hline Marion & 25,855 & 17,496 & 38,785 & $-32.3 \%$ & $121.7 \%$ & $50.0 \%$ \\
\hline Marshall & 360,647 & 389,689 & 418,590 & $8.1 \%$ & $7.4 \%$ & $16.1 \%$ \\
\hline Martin & 125,947 & 93,136 & 80,478 & $-26.1 \%$ & $-13.6 \%$ & $-36.1 \%$ \\
\hline Miami & 309,200 & 347,075 & 412,664 & $12.2 \%$ & $18.9 \%$ & $33.5 \%$ \\
\hline Monroe & 29,283 & 70,607 & 102,089 & $141.1 \%$ & $44.6 \%$ & $248.6 \%$ \\
\hline Montgomery & 661,284 & 617,138 & $1,093,553$ & $-6.7 \%$ & $77.2 \%$ & $65.4 \%$ \\
\hline Morgan & 289,531 & 248,360 & 305,606 & $-14.2 \%$ & $23.0 \%$ & $5.6 \%$ \\
\hline Newton & 409,624 & 467,450 & 519,855 & $14.1 \%$ & $11.2 \%$ & $26.9 \%$ \\
\hline Noble & 282,569 & 263,102 & 312,533 & $-6.9 \%$ & $18.8 \%$ & $10.6 \%$ \\
\hline Ohio & 17,368 & 15,480 & 14,000 & $-10.9 \%$ & $-9.6 \%$ & $-19.4 \%$ \\
\hline Orange & 88,948 & 93,684 & 101,018 & $5.3 \%$ & $7.8 \%$ & $13.6 \%$ \\
\hline Owen & 263,198 & 206,579 & 261,627 & $-21.5 \%$ & $26.6 \%$ & $-0.6 \%$ \\
\hline Parke & 278,876 & 279,297 & 289,088 & $0.2 \%$ & $3.5 \%$ & $3.7 \%$ \\
\hline Perry & 55,105 & 65,677 & 68,456 & $19.2 \%$ & $4.2 \%$ & $24.2 \%$ \\
\hline Pike & 164,724 & 166,686 & 176,964 & $1.2 \%$ & $6.2 \%$ & $7.4 \%$ \\
\hline Porter & 235,972 & 320,434 & 267,611 & $35.8 \%$ & $-16.5 \%$ & $13.4 \%$ \\
\hline Posey & 256,412 & 246,902 & $3,047,342$ & $-3.7 \%$ & $1134.2 \%$ & $1088.5 \%$ \\
\hline Pulaski & 537,384 & 662,264 & 771,496 & $23.2 \%$ & $16.5 \%$ & $43.6 \%$ \\
\hline Putnam & 273,855 & 368,441 & 1,599,193 & $34.5 \%$ & $334.0 \%$ & $484.0 \%$ \\
\hline Randolph & 439,623 & $2,312,981$ & $1,022,793$ & $426.1 \%$ & $-55.8 \%$ & $132.7 \%$ \\
\hline Ripley & 416,348 & 332,651 & 404,606 & $-20.1 \%$ & $21.6 \%$ & $-2.8 \%$ \\
\hline Rush & 500,107 & 468,285 & 542,432 & $-6.4 \%$ & $15.8 \%$ & $8.5 \%$ \\
\hline Scott & 63,578 & 59,874 & 62,750 & $-5.8 \%$ & $4.8 \%$ & $-1.3 \%$ \\
\hline Shelby & 457,924 & 395,194 & 461,354 & $-13.7 \%$ & $16.7 \%$ & $0.7 \%$ \\
\hline
\end{tabular}




\begin{tabular}{lrrr|rrr}
\hline \multirow{2}{*}{ County } & \multicolumn{3}{c|}{ VTMS per Year } & \multicolumn{3}{c}{ \% Change in VTMS from: } \\
\cline { 2 - 7 } & \multicolumn{1}{c}{2006} & \multicolumn{1}{c|}{2008} & 2010 & 06 to 08 & 08 to 10 & 06 to 10 \\
\hline Spencer & 225,467 & 239,035 & 269,686 & $6.0 \%$ & $12.8 \%$ & $19.6 \%$ \\
St. Joseph & $1,370,567$ & 615,868 & 689,814 & $-55.1 \%$ & $12.0 \%$ & $-49.7 \%$ \\
Starke & 306,908 & 321,443 & 375,715 & $4.7 \%$ & $16.9 \%$ & $22.4 \%$ \\
Steuben & 153,960 & 180,918 & 147,430 & $17.5 \%$ & $-18.5 \%$ & $-4.2 \%$ \\
Sullivan & 279,730 & 290,646 & 308,754 & $3.9 \%$ & $6.2 \%$ & $10.4 \%$ \\
Switzerland & 34,050 & 44,332 & 35,777 & $30.2 \%$ & $-19.3 \%$ & $5.1 \%$ \\
Tippecanoe & 254,584 & 252,157 & 257,580 & $-1.0 \%$ & $2.2 \%$ & $1.2 \%$ \\
Tipton & 336,878 & 391,001 & 372,557 & $16.1 \%$ & $-4.7 \%$ & $10.6 \%$ \\
Union & 167,788 & 148,548 & 167,363 & $-11.5 \%$ & $12.7 \%$ & $-0.3 \%$ \\
Vanderburgh & 97,710 & 92,554 & 144,505 & $-5.3 \%$ & $56.1 \%$ & $47.9 \%$ \\
Vermillion & 103,044 & 118,895 & 129,758 & $15.4 \%$ & $9.1 \%$ & $25.9 \%$ \\
Vigo & 208,281 & 185,199 & 201,491 & $-11.1 \%$ & $8.8 \%$ & $-3.3 \%$ \\
Wabash & 496,464 & $1,379,278$ & 632,324 & $177.8 \%$ & $-54.2 \%$ & $27.4 \%$ \\
Warren & 568,316 & 622,299 & 692,104 & $9.5 \%$ & $11.2 \%$ & $21.8 \%$ \\
Warrick & 290,735 & 265,673 & 130,587 & $-8.6 \%$ & $-50.8 \%$ & $-55.1 \%$ \\
Washington & 113,479 & 97,993 & 98,969 & $-13.6 \%$ & $1.0 \%$ & $-12.8 \%$ \\
Wayne & 388,321 & 326,927 & 361,332 & $-15.8 \%$ & $10.5 \%$ & $-7.0 \%$ \\
Wells & 380,955 & $2,796,732$ & $2,683,890$ & $634.1 \%$ & $-4.0 \%$ & $604.5 \%$ \\
White & 814,816 & 827,741 & 904,353 & $1.6 \%$ & $9.3 \%$ & $11.0 \%$ \\
Whitley & 316,878 & 282,495 & 333,168 & $-10.9 \%$ & $17.9 \%$ & $5.1 \%$ \\
\hline
\end{tabular}

